\title{
Orchard Insects of
}

\section{the Pacific Northwest} and Their Control

\author{
E. J. NEW COMER, Senior Entomologist \\ Division of Fruit Insect Investigations \\ Bureau of Entomology and Plant Quarantine
}

For sale by the Superintendent of Documents, Washington, D. C., Price 15 cents

\section{UNITED STATES DEPARTMENT OF AGRICULTURE}

WASHINGTON, D. C., JUNE 1941 

Historic, archived document

Do not assume content reflects current scientific knowledge, policies, or practices. 


\section{Reasons for Controlling Fruit Insects}

The importance of fruit in a well-balanced diet is receiving increasing recognition. During the present war emergency the maintenance of an adequate diet is especially important to the armed forces, to the civilian population, and to our allies. The production of fruit of high quality in large volume is virtually impossible unless adequate measures are taken for controlling insect pests that, in the absence of such control effort, often destroy entire crops of fruit. At the present time the control of insects that attack fruit crops is a definite part of the war effort.

\section{Availability of Insecticides}

During the present war emergency, difficulty may be experienced in obtaining needed insecticides. Some of the materials that enter into the manufacture of insecticides may be needed more urgently elsewhere in the war effort, manufacturing facilities ordinarily used in the production of insecticides may be diverted to other uses, and supplies of insecticides of foreign origin may be cut off. Recognizing the essential nature of insect control, however, the agencies concerned with the war effort are doing everything possible to insure a reasonably adequate supply of insecticides to protect food crops. Because the situation is likely to change rapidly, statements on specific materials will not be made at this time.

Growers should place their orders for insecticides well in advance, to insure delivery when needed, or to allow time to obtain the best possible substitute if standard materials are not to be had. Growers should not, however, buy in excess of the current season's needs, since this may deprive some other grower of vitally needed insecticides. Spray materials should be used at the minimum effective strength, and waste should be avoided.

Current information on the availability of insecticides, or about substitutes for standard materials that cannot be procured, may be obtained from county agricultural agents, State experiment stations or extension services, or from the United States Department of Agriculture at Wash. ington, D. C.

\section{Cautions To Be Observed in Using Poisons}

Many of the insecticides listed in this circular are extremely poisonous to human beings and to animals, and should be stored and handled with the greatest of care. Stocks of such materials should be kept in closed containers and marked in such a way that there will be no danger of 
Issued August 1933, slightly revised July 1942

Washington, D. C.

Orchard Insects of the Pacific Northwest and Their Control

By E. J. Newcomer, senior entomologist, Division of Fruit Insect Investigations, Bureau of Entomology and Plant Quarantine ${ }^{1}$

\section{CONTENTS}

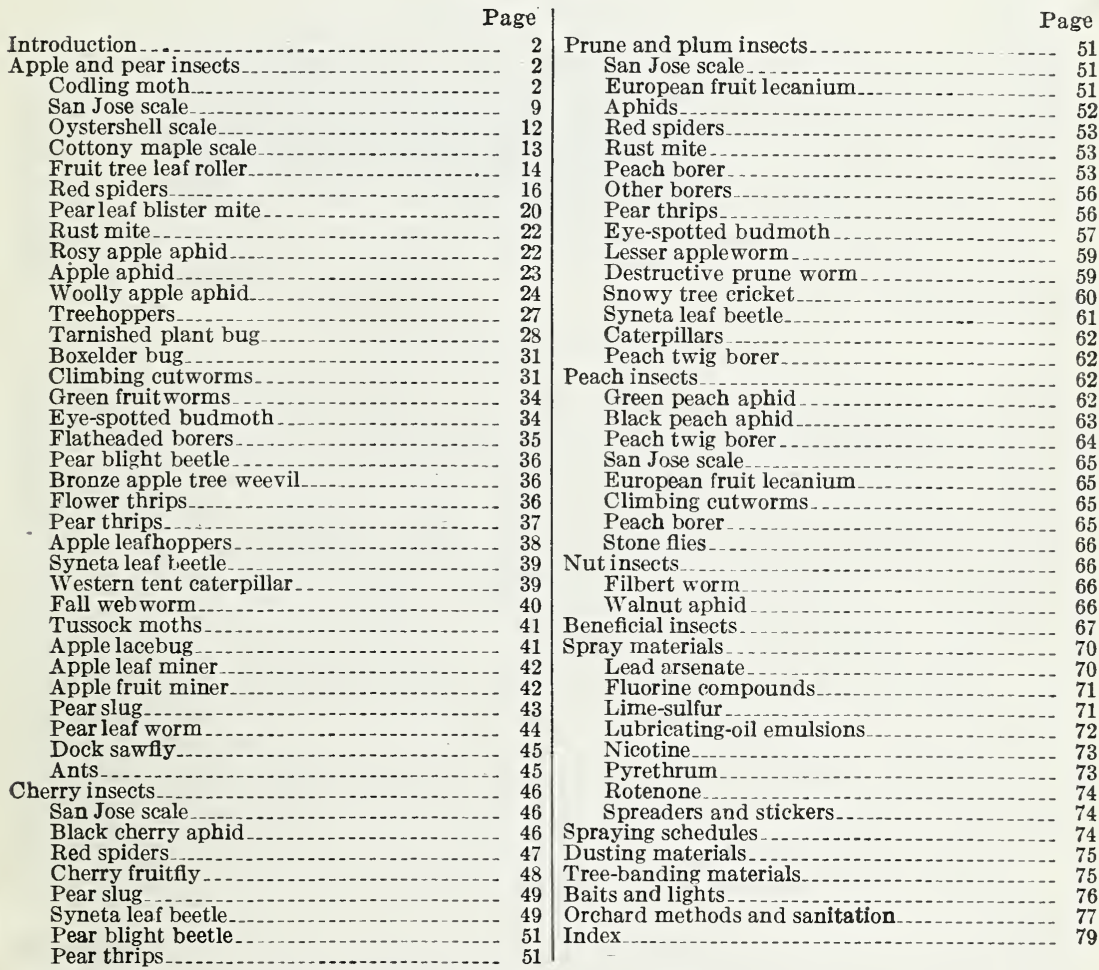

1 Credit is given to the following authors for illustrations in this circular which have appeared in earlier publications: A. L. Quaintance and E. H. Siegler, figures $2,3,6,7,8,10,11,13,14,15,16,18,20,21,23,25$, $26,28,37,38,39,41,42,43,44,47,48,50,51,55,68$, and 72; E. J. Newcomer and $M$. A. Yothers, figures 4

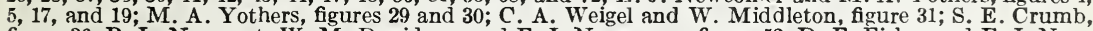
figure 36; R. L. Nougaret, W. M. Davidson, and E. J. Newcomer, figure 52; D. F. Fisher and E. J. Newcomer, figure 58; A. L. Quaintance and A. C. Baker, figures 60,71 , and $77 ; 0$. I. Snapp, figures 61 and 62 B. A. Porter, figure 66; F. H. Chittenden, figure 75; E. A. McGregor, figure 76; and C. L. Marlatt, figure 79. The photograph for figure 49 was furnished by the Oregon Agricultural Experiment Station and the photograph for figure 67 was furnished by the Idaho Agricultural Experiment Station. The assistance of members of the staff of the Yakima, Wash., laboratory of the Bureau of Entomology and Plant Quarantine, and of members of the various experiment stations in the Pacific Northwest is gratefully acknowledged. 


\section{INTRODUCTION}

The production of deciduous-tree fruits constitutes one of the important industries of the Pacific Northwest. In recent years the average annual value of these crops produced in Washington and Oregon is said to have been approximately $\$ 40,000,000$. The annual loss due to insects in the United States, including the actual loss of fruit and the cost of combating the insects, has been conservatively estimated at 10 percent of the value of the crop. This does not seem too high for the Pacific Northwest, and it is thus apparent that insects take an annual toll of at least $\$ 4,000,000$ from the fruit growers in this region. This circular gives information about the most important insects found in the orchards of Oregon, Washington, Idaho, and western Montana.

\section{APPLE AND PEAR INSECTS}

\section{Codling Moth}

No insect causes greater loss to apple and pear growers in the Pacific Northwest than does the codling moth (Carpocapsa pomonella (L.)). Individual growers may lose more than 50 percent of the crop, but by using proper control methods they could usually keep the losses below 5 percent. The codling moth occurs in all the applegrowing districts of the West, having been accidentally introduced from Europe into the Eastern States and thence transmitted to the Pacific coast.

\section{NATURE OF INJURY}

The larva or worm is the only injurious stage of the codling moth, and the only injury of consequence is to the fruit. The young worms, upon hatching from the eggs, crawl to the nearest fruit and burrow into it, producing the familiar wormy apple or pear. Many worms enter through the calyx end, where the calyx affords them protection and they can easily obtain a foothold. Many others enter at the point where two fruits touch, or where a leaf is in contact with a fruit. Still others are able to burrow into the exposed side of the fruit. The worm penetrates the skin and excavates a small cavity beneath it in an hour or so. It remains near the surface for a few days and then burrows to the center of the fruit, usually feeding chiefly on the seeds and core. When full grown the worm makes a large tunnel to the surface through which it leaves the fruit. Wormy fruit is of small commercial value, since it will not keep long, and the laws of some States forbid its being shipped, except to byproducts plants.

A form of injury other than the tunneling is the "sting" (fig. 1), caused by a worm that started to burrow into the fruit and then died, usually as the result of feeding on poison spray on the fruit. This poison acts rather slowly, and the worm often makes a small burrow before it dies. Stings range from pin-point size, made by worms that have just succeeded in puncturing the skin, to an eighth 
of an inch or more in diameter, the larger holes being made by worms that have fed for several hours. Holes of the latter size often cause the fruit to be classified as culls, for although it is not actually wormy it is so injured that it is very liable to decay. Smaller stings, if properly healed so that decay will not follow, are not so important, and fruit having them is ordinarily not culled out altogether, but is somewhat lowered in grade. Worms occasionally feed for a time in rapidly growing twigs or in the midribs of leaves, but this injury is of no consequence, a $\mathrm{n} d$ such worms are not likely to mature.

\section{LIFE HISTORY}

The codling moth passes the winter as a worm in a cocoon (fig: 2) about three-fourths of an inch long which is constructed under

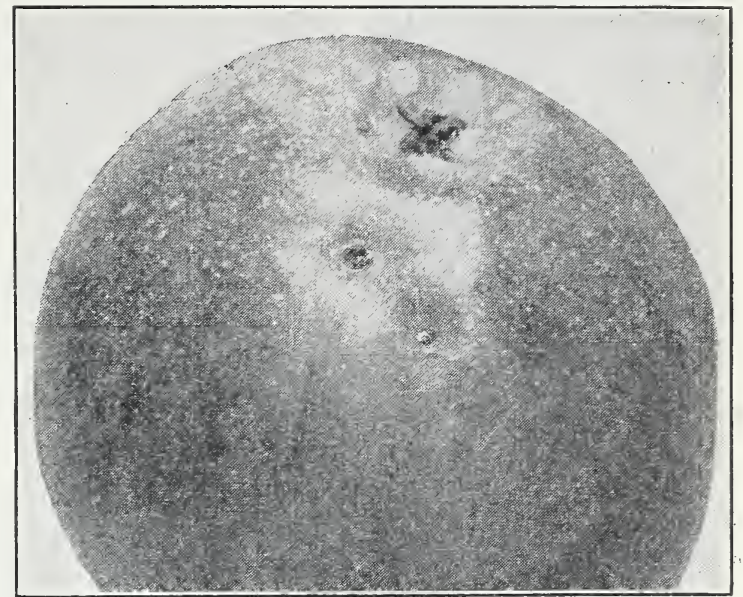

Figure 1.- "Stings" produced by codling moth worms on apple.

the loose bark of the trees, in cracks and crevices on the trunks, attached to the trunk just below the surface of the ground, or in protected places in boxes, sacks, and packing sheds. The overwintering worm just about fills the cocoon and is dirty white or pinkish, with a brown

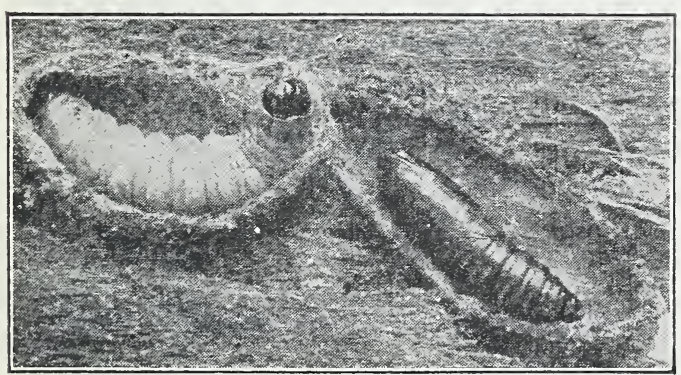

Frgure 2.-Codling moth larva and pupa in cocoons. $\times 2$. head. All of the last brood of worms that left the fruit before it was packed, and a part of the preceding brood, hibernate. In the spring the worms construct exit tubes of silk, transform to pupae, and later to moths, which escape through the exit tubes. The first moths appear about the time Winesap apple trees are in bloom, and the largest numbers of moths are flying late in Nay or early in June. The moths (fig. 3) are rather inconspicuous, having a maximum wing spread of about three-fourths of an inch. The front or upper wings are brownish gray, crossed with lines of lighter gray, and with a bronze band at the tip. The hind wings, which are covered when the moths are at rest, are grayish brown. The moths live for about 2 weeks. They lay most of their eggs between sundown and 9 or 10 p. m., but 
very few eggs are laid if the temperature at this time is below $60^{\circ} \mathrm{F}$. Under favorable temperatures most of the eggs are laid during the second, third, and fourth evenings after the moths have emerged, but in the spring cool weather may prevent egg

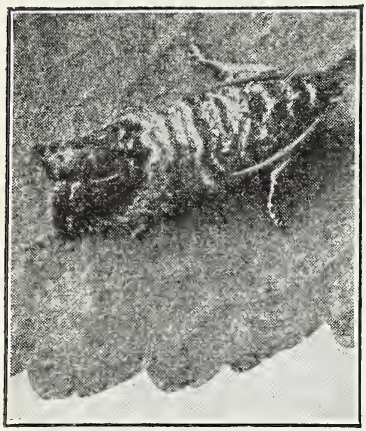

FIgURE 3.-Codling moth. laying altogether for a week or more. The eggs (fig. 4) are pearly white, about the size of pinheads, and resemble thin convex disks. A few days after it is laid a red ring appears in the egg, and the day before the worm hatches a black spot, the head of the worm, is easily seen. Most of the first-brood eggs are laid on the leaves surrounding the small fruits.

The earliest-laid eggs are usually subjected to cool weather and the worms do not hatch for 12 to 14 days. As the temperature becomes higher, the incubation period of the egg shortens, the minimum being 5 days, although in extremely cool weather it may be as long as 3 weeks. Worms are hatching from eggs and entering the fruit for about 5 weeks, and are most numerous during June. These worms feed in the fruit for about 3 weeks and then leave it and spin cocoons. About 75 percent of them continue their development into pupae and moths, but the others remain in the cocoons until the following season. The worms that transform

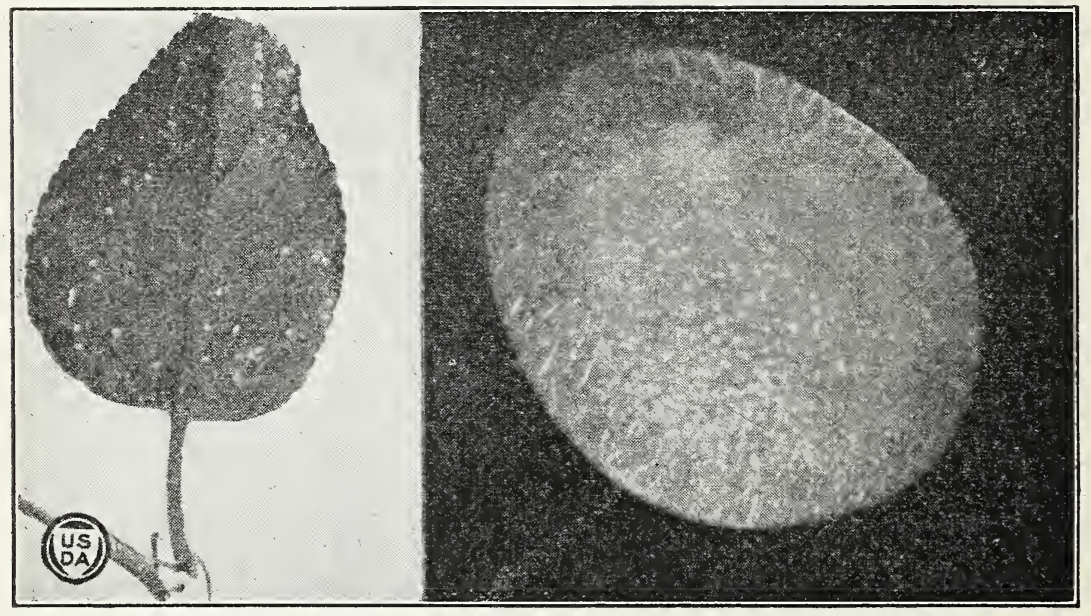

FIGURE 4.--Codling moth eggs: Left, natural size on apple leaf; right, single egg. $\times 35$.

pass through the pupal period in about 2 weeks, and the first individu als of the second brood of moths appear early in July. After this time moths are present in large numbers until cool weather in the fall, the first period of stormy weather in September usually ending the activities of the moths for the season. Many eggs of the second brood are laid on the fruit, and during the warm weather of July and August 
they ordinarily hatch in 6 or 7 days. The worms often remain in the fruit for more than a month in the fall, and many of them are still there when it is picked. They may leave the fruit before it is packed, and for this reason large numbers of wintering worms in their cocoons may be found in picking boxes and packing sheds.

The codling moth is very sensitive to variations in temperature. In the warmer localities there is often a partial third generation, but at greater elevations and along the coast there is no third generation and the second generation is smaller than elsewhere. In any locality the yearly abundance of worms varies greatly, as it is dependent on weather conditions. Winter temperatures of $-15^{\circ} \mathrm{F}$. or colder kill some of the overwintering worms. Probably the most important effect of temperature occurs during May and June, when large numbers of first-brood eggs are laid if the weather is warm, but the number is greatly reduced if it is cold or rainy. Thus an early, warm season produces many worms, but a late cool season has the opposite effect. The fruit grower should therefore study weather conditions as well as conditions in his orchard and plan his spraying schedule accordingly.

\section{CONTROL}

Spraying the fruit to protect it from the codling moth is not always sufficient if the infestation is severe. In such cases supplemental measures are necessary. The trees should be scraped thoroughly to remove all the loose bark under which cocoons might be spun. Bands of corrugated paper, treated with a mixture of beta-naphthol and oil, ${ }^{2}$ may then be placed on the trees not later than the first week of June. Many worms will spin cocoons in the bands and will be destroyed by the chemical. The bands should be removed and burned the following winter and fresh ones applied the next year. This method will often destroy over half of the worms that leave the apples. In pruning, trees should be kept open enough to permit all parts to be sprayed thoroughly. Each cluster should be thinned to a single fruit and all wormy fruit removed and destroyed. Worms that have spun cocoons in picking boxes and packing sheds should be destroyed or the resulting moths prevented from reaching the orchard. The boxes may be placed in a shed that is kept tightly closed during the spring and summer to prevent the escape of the moths, or boxes and sheds may be sterilized. ${ }^{3}$

Maximum efficiency is not so easily attained in spraying for the codling moth as in spraying for other pests, because more sprays are necessary, and the time of application is more important, since a spray applied at the wrong time may be largely wasted and the fruit left unprotected when large numbers of worms are hatching. Other orchard operations, such as irrigating, cultivating, thinning, and the handling of alfalfa cover crops, should not be allowed to interfere with the spray schedule. It is more difficult to determine the proper time for applying codling moth sprays than for applying any of the other sprays used by the fruit growers of the Pacific Northwest, as the time differs from year to year.

2Information on how to make and use these treated bands may be obtained from the Bureau o Entomology and Plant Quarantine, U. S. Department of Agriculture, Washington, D C.

${ }^{3}$ Information on a method of sterilizing boxes with steam may be obtained from the Bureau of Entomology and Plant Quarantine, U. S. Department of Agriculture, Washington, D C 
The calyx spray is applied for the purpose of depositing enough poison in the calyx cup to kill all the worms that attempt to enter the

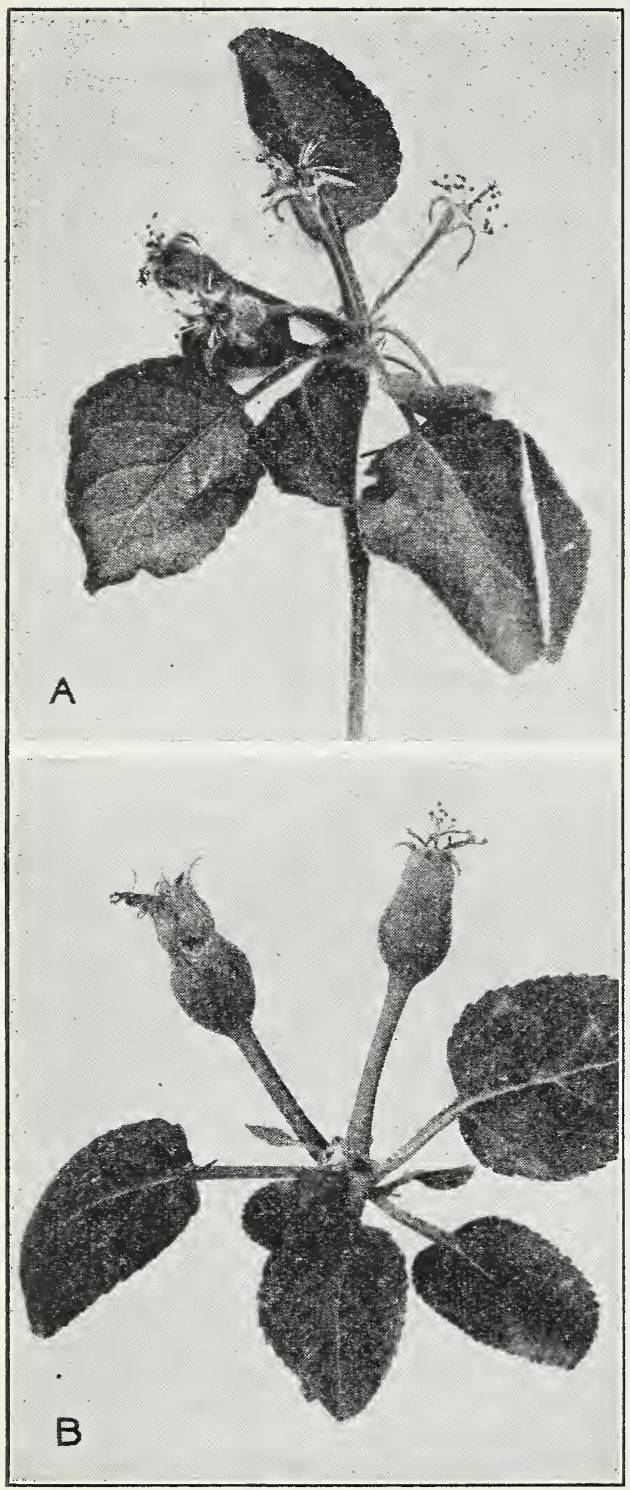

Figure 5.-A, Apple blossoms from which the petals have just fallen; the right stage at which to apply the calyx spray for the codling moth; $\mathrm{B}$, too far advanced for calyx spray. fruit at that place. Since more than half of all the worms may attempt to enter the fruit through the calyx, it is very important that the calyx spray be applied thoroughly. Spraying should begin as soon as most of the petals have dropped (fig. 5, A) and should be completed before many of the calyx cups have closed (fig. 5, B).

In certain favored localities, particularly along the coast, spraying may not be necessary at all, or perhaps the calyx spray will suffice. In most of the region, however, one or more cover sprays are required, the number depending on the altitude, climate, degree of codling - moth infestation, and other factors. In the great majority of apple orchards in the Pacific Northwest five or six cover sprays should be used, three or four for the first brood and two for the second brood. (See spraying schedules, p. 75.)

It is very important that the first-brood sprays be applied thoroughly and at the proper time, to eliminate as far as possible the first brood of worms. The first cover spray should be applied from 8 to 21 days after the calyx spray, depending on temperature, and is the most difficult to time properly. However, it may be timed by observing the numbers of moths entering baits placed in the trees (p. 76), and also the temperatures registered at $8 \mathrm{p} . \mathrm{m}$. by a thermometer hung in the orchard away from the buildings. These observations should begin as soon as the trees are in bloom. When two or more consecutive 
nights occur with temperatures of about $60^{\circ} \mathrm{F}$. or higher at $8 \mathrm{p} . \mathrm{m}$., after the appearance of numbers of moths in the baits, the cover spray should be completed within 8 or 10 days. In most localities two or more cover sprays are necessary for the first brood, and these should be applied at intervals of about 10 days or 2 weeks, using the baits as indicators of the activity of the moths.

The second-brood worms begin to hatch about 8 or 10 weeks after the petals have fallen. The influx of increasing numbers of moths in the baits during July will give an accurate indication of the need for second-brood spraying, which should begin as soon as a definite increase occurs. In moderately infested orchards 1 more cover spray about 4 weeks later is sufficient, but in many cases 2 or more additional sprays, at intervals of 2 or 3 weeks, are needed.

Pears ordinarily do not become so wormy as apples, particularly when interplanted with them, the moths showing a preference for the apples.' In solid plantings of pears, the fruit often becomes decidedly wormy unless properly sprayed. A calyx spray should always be applied, but as the pear calyces do not close rapidly, there is more time in which to apply this spray to pears than to apples. Following the calyx spray, a cover spray should be given about 4 weeks after the petals have dropped. Where pears are interplanted with apples, they may be sprayed at the same time as the apples. In the warmer sections it is necessary to apply further cover sprays according to the seriousness of the infestation. Bartlett or other early varieties should not be sprayed after the end of July, as they are usually harvested in August. If only one spray is needed, it may be applied at the time of the first cover spray for apples, and will act as a combined calyx and cover spray, because most of the calyx cups in pears remain open until after this time. If experience has indicated that this one spray is insufficient, a calyx spray should be applied earlier in the season, because pears are more subject to calyx worms than apples and need more protection in the calyx. (See spraying schedules, p. 75.) In order to facilitate an even distribution of the spray over the smooth waxy surface of the pears and to prevent objectionable blotching of the mature fruit, a spreader should be used in the cover sprays.

On account of the importance of codling moth sprays, adequate spraying machinery is essential. Much of the failure to control the worms is due to the use of spray outfits that are too small or are in poor condition. In many cases stationary spraying systems are much more efficient than portable outfits. Sufficient pressure should be maintained to enable the operator to reach the tops of the trees easily, and the tops should be sprayed with especial care, since it is more difficult to cover thoroughly fruit in the tops than that which is nearer the ground.

A number of insecticides may be used for controlling the codling moth. Chief of them is acid lead arsenate. The powdered form is ordinarily used at the rate of 3 pounds to 100 gallons of water, but in severely infested orchards this quantity may be increased to 4 pounds. Fish oil and certain colloidal materials, ordinarily known as spreaders, may be used to advantage to cause a larger quantity of lead arsenate to adhere to the fruit, or to prevent blotching. Fish oil may be used in the proportion of 1 pint or 1 quart to 100 gallons of spray. Other spreaders or stickers should be used as recommended 
by the manufacturers. If lime-sulfur solution must be used for the control of scab or powdery mildew, it may be combined with the lead arsenate. The lime-sulfur should be put into the tank while it is being filled, and the lead arsenate added just before beginning to spray. The mixture should be used at once on account of a chemical reaction which occurs. This reaction may be retarded by putting casein spreader or hydrated lime into the tank before the other materials are added, using them at the rate of 1 pound to 100 gallons of spray.

Residues of arsenic or lead, in quantities sufficiently great to constitute a menace to the health of the consumer, must be removed by washing or wiping before the fruit is sold. Although this is not ordinarily difficult, ${ }^{4}$ the grower should avoid spray schedules that may result in excessive residues. Calcium arsenate, which contains no lead, may be used for light infestations, although this material may cause burning and does not usually control as well as lead arsenate.

Mineral-oil emulsions (p. 72) are very valuable for controlling the codling moth if used in conjunction with the arsenical or some other material. Enough emulsion should be used so that the diluted spray contains from one-half to three-fourths of 1 percent of actual oil, and not more than four applications should be made in a season. The type of oil to use is explained on page 72. Oil emulsions may cause a severe drop of fruit and foliage if applied on trees that have received sulfur sprays within 2 months. Therefore, when the use of sulfur sprays is necessary for the control of apple powdery mildew or other fungous diseases, oil cannot be used with safety in the early cover sprays. Oil may be used most effectively when most of the eggs are on the trees, since its chief value lies in its ability to destroy eggs. It will generally be most valuable if added to the second and third cover sprays for the first brood, and to one or more sprays for the second brood. Since it also causes the lead arsenate to adhere more firmly to the fruit and foliage, there will be difficulty in removing the spray residue if the combination of oil emulsion and arsenical is used in the second-brood sprays. In place of the arsenical, nicotine sulfate (40 percent nicotine) may be combined with the oil emulsion, using it in the proportion of two-thirds to 1 pint to 100 gallons of spray. Since this combination interferes greatly with residue removal, not more than two or three applications of lead arsenate should be made preceding its use. If the infestation is light, especially if pears are to be sprayed, it may be sufficient to use this combination of nicotine sulfate and oil emulsion for all the cover sprays.

In the arid valleys cryolite (sodium fluoaluminate), in the proportion of 3 pounds to 100 gallons of water, may be used in the cover sprays. This material should not be used alone but only in conjunction with an oil emulsion or with fish oil. One pint of the latter to 100 gallons of spray is the most satisfactory addition to cryolite. Excessive residues from this material must be removed by wiping or washing the fruit before it is marketed.

4 Detailed instructions for removing spray residues may be found in Farmers' Bulletin 1752, Spray-residue Removal from Apples and Other Fruits. 


\section{San Jose Scale}

The San Jose scale (Aspidiotus perniciosus Comst.) is potentially capable of doing more damage than any other insect occurring in the orchards of the Pacific Northwest. It not only renders the fruit unmarketable, but it kills the twigs and limbs, and, if not controlled, it eventually kills the tree or at least so devitalizes it that it is worthless. Actually, the amount of damage done by the San Jose scale is much less than that caused by the codling moth, because effective control is easier, and fruit growers generally know the danger and keep the scale under control.

The scale insect feeds by sucking the plant juices from the twigs and larger branches and from the fruit and foliage. It causes small reddish spots, particularly on the fruit, and the presence of the scale is often first made evident by the appearance of these spots (fig. 6). The red discoloration also occurs on scale-infested leaves and in the bark. It cannot be seen on the surface of the bark, but is disclosed by cutting into infested twigs or limbs. The bark has a roughened and grayish appearance (fig. 7), and if it is scraped a yellowish liquid, coming from the crushed bodies of the insects, appears. Infestations are also manifested by dead twigs scattered about the tree and by the tendency of the leaves on infested branches to remain on the trees during winter.

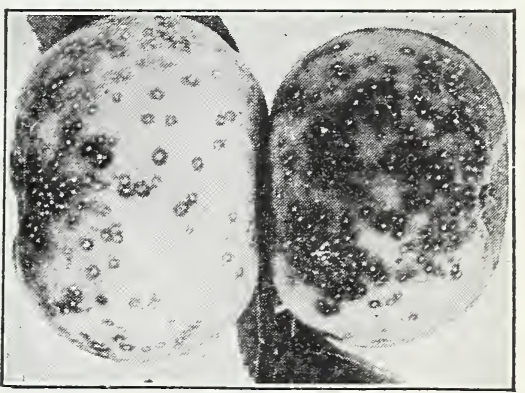

FIgURe 6.-Apples spotted by the San Jose scale.

In irrigated districts, however, apple leaves often remain on uninfested trees for at least a part of the winter. Although present methods of control are adequate and are keeping the scale in check, an infestation should not be regarded lightly. If spraying is neglected the scales can become very numerous in a surprisingly short time under favorable conditions, as the progeny of a single female may amount to several million insects in one season. Laws in some States prohibit the marketing of infested fruit except for the purpose of making byproducts, and quarantine regulations prohibit the entrance of infested fruit into certain foreign countries.

The San Jose scale is so named because it was first found at San Jose, Calif. It is native to China and was evidently brought into California with plants of some kind about 1870 . It has since been widely distributed on nursery stock and by other means, and at present occurs in practically all the fruit districts in the United States. It does more harm to apple and pear trees than to other fruits, but is at times a serious pest of sweet cherry, peach, and prune trees. It also attacks other deciduous fruit trees, nuts, and berries, as well as many kinds of shade trees and ornamental shrubs, among them the mountainash, currant, dogwood, elm, gooseberry, hawthorn, lilac, linden, poplar, snowberry, willow, and the ornamental flowering $291255^{\circ}-41-2$ 
varieties of fruit trees. Many of these plants or trees grow in the gardens or about the houses in fruit-growing districts, and unless they are regularly inspected and are sprayed, if infested, they arc

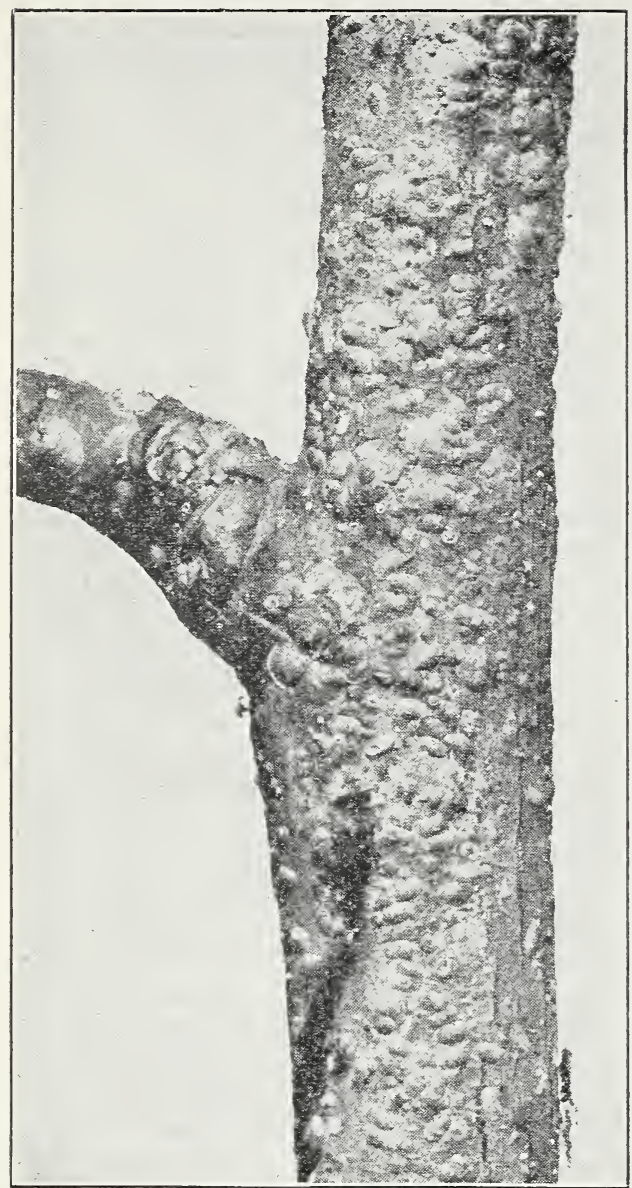

FigURe 7.-Bark encrusted with the San Jose scale. $\times 5$. time. During their period of activity they are often carried to other trees by the wind, on the feet of birds, on the clothing of men working in the orchards, or on horses or farm implements. They ordinarily settle down within a few hours on the bark or on leaves or fruit, insert their long, threadlike beaks into the plant tissue, and commence feeding. Almost at once they begin to secrete a waxy material which soon forms a characteristic, circular, scalelike covering. The covering of the female when fullgrown is about the size of a pinhead, grayish, with a dark, central, nipplelike projection, while that of the male is somewhat elongated (fig. 8). If these coverings are turned over, the delicate, bright-yellow, saclike bodies of the insects may be seen. Growth is completed in about 6 weeks, and there are two or more generations in a season. some centers of infestation for nearby orchards.

The San Jose scale remains in one place during most of its life. In the fall be found on the trees, but only those that are about half grown survive the winter, and in severe winters many of these succumb. Temperatures of $-15^{\circ}$ to $-20^{\circ} \mathrm{F}$. cause a mortality of approximately two thirds of the half-grown scales, and 90 percent or more are killed if the temperature gets as low as $-25^{\circ}$ or $-30^{\circ}$. In the spring the scales that have survived continue their growth and mature in May or June. The males develop wings and are active, although they do little flying. The males have no wings, redeveloped and producing several hundred very small, louselike, yellowish, active young. These young are capable of crawling considerable distances during the first few hours of their lives, and spread about at that

very likely to be trouble- 


\section{CONTROL}

Ordinary infestations may be controlled by a single thorough application of hubricating oil emulsion or lime-sulfur solution during the dormant season. More than 1 year may be required to bring very heary infestations under control, but this may be accomplished by spraying the trees twice in one season. If two applications are made, one should be made in the fall, if possible, and the other in the spring. Not more than one application of oil at dormant-season strength should be made in a year, and if two applications for the scale are contemplated, the first should be of lime-sulfur solution. The second may be either oil emulsion or lime-sulfur.

The question of which material to use depends on what other insects are on the trees at the time the spray is applied. Oil sprays are very effective against the eggs of red spiders, treehoppers, and the fruit tree leaf roller, and against newly hatched aphids, and should be used if these eggs or insects are numerous.

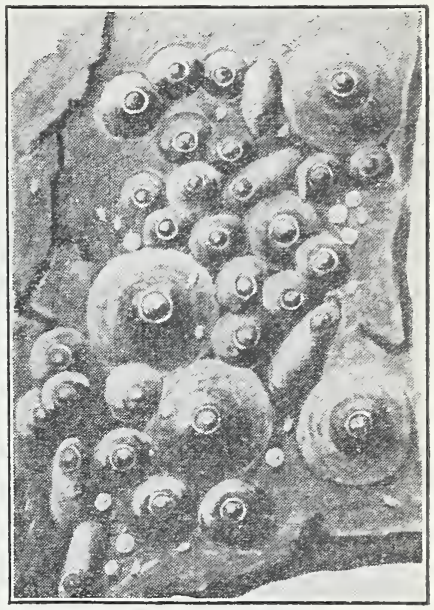

Figure 8.--San Jose scale: Males and females. $\times 8$.

Otherwise, the lime-sulfur solution is just as satisfactory. It is often desired to control the pear leaf blister mite, on pear trees, and for this

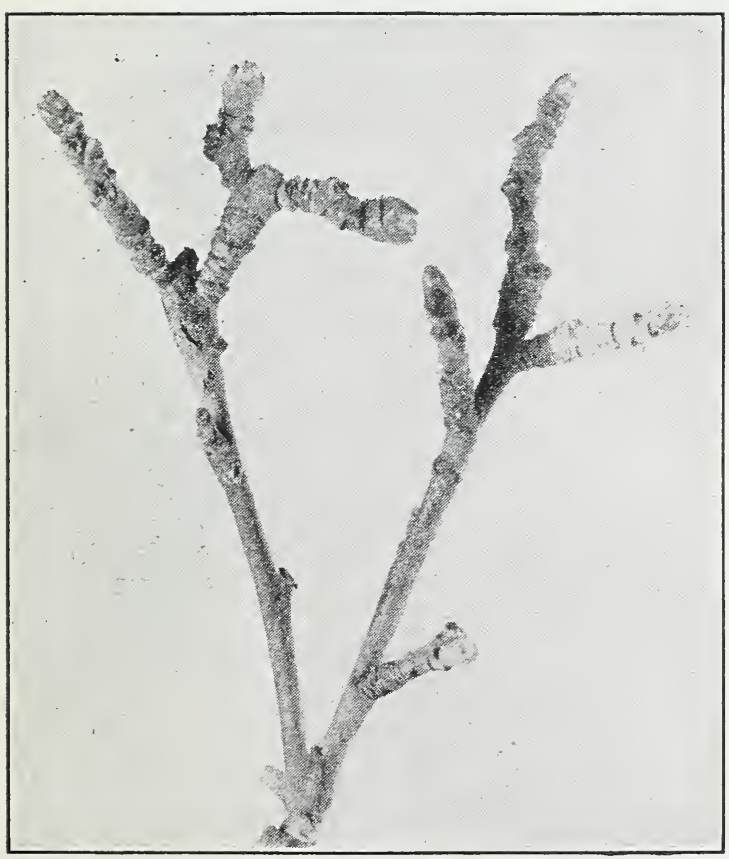

FIGURE 9.-Apple buds in proper condition for dormant spray. purpose lime-sulfur solution is preferable (p. 71).

This solution is perhaps safer for use during the delayed dormant period than oil emulsion, although a sudden onset of warm weather following its application will at times cause a dropping of the fruit buds. The safest procedure is to use these materials only while the trees are still dormant (fig. 9). Preferably the spray should be applied after the pruning is finished, as less material is required then, and the more heavily infested limbs may often be removed before spraying. It may sometimes benec- 
essary also to scrape rough bark from the trees and to clean out any cankers in order that the spray may reach all parts of the trunk and limbs.

On medium or heavy infestations of the San Jose scale, lubricating oil emulsion must be used at a dilution containing about 4 percent of oil, to obtain satisfactory results, although a dilution containing 3 percent of oil may be sufficient for very light infestations. Limesulfur solution must test at least $4 \frac{12^{\circ}}{}$ Baumé for most infestations.

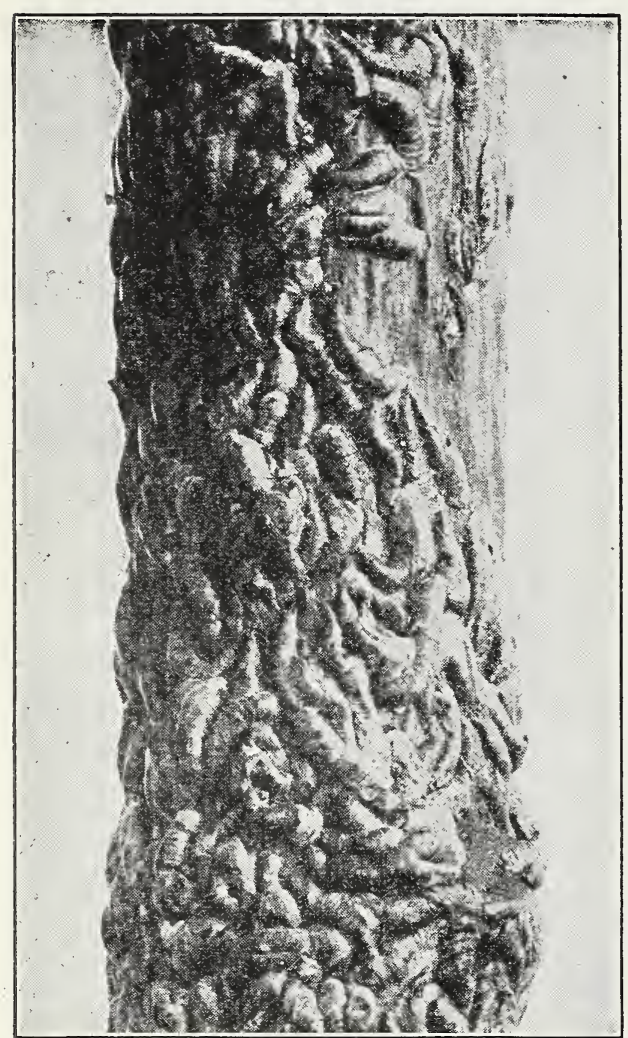

Frgure 10.- Twig encrusted with the oystershell scale. $\times 4$. This requires 11 gallons of a concentrate testing $32^{\circ}$ Baumé to make 100 gallons of spray. Very light infestations may be held in check with a dilution testing at least $3 \frac{1 / 2}{2}$ Baumé, requiring 8 gallons of $32^{\circ}$ Baumé concentrate for 100 gallons. (For schedules of oil and limesulfur dilutions, see pp. 73 and 71).

If the dormant-season applications have not proved adequate, summer-strength applications of about 1 percent oil emulsion, such as are used for the codling moth and red spider, or. of limesulfur concentrate (1 gallon to 50 gallons) as employed for combating the apple powdery mildew, should considerably reduce the amount of fruit spotted by the scale, if applied during June or August, when most of the young scales are present.

\section{Oystershell Scale}

The oystershell scale (Lepidosaphes ulmi (L.)) is found throughout the Northwest, but occurs most commonly west of the Cascade Mountains and is seldom seen in the irrigated valleys of the interior. It is readily distinguishable from other scale insects by its characteristic shape (fig. 10). The apple is a favorite food plant of this scale, but it also lives on a great variety of fruit and shade trees, ornamental shrubs and plants, and on native trees, such as willow and dogwood. Its effect on the tree and fruit is similar to that of the San Jose scale, and heavily encrusted trees or limbs may be killed.

\section{LIFE HISTORY}

If the old scales on the bark be turned over during the winter, they will be found filled with small, pearly white, oval eggs (fig. 11). 
Often there are nearly 100 eggs beneath a single scale. These eggs hatch shortly after the apple trees bloom, and the minute, whitish young crawl out and settle in a few hours on some living part of the plant. They develop slowly, increasing the size of the scale coverings as they grow, until, in the case of the females, the scales are about one-eighth of an inch long when completed, dark brownish gray, and shaped somewhat like oyster shells. The male scales are smaller and oval, and the mature males emerge from the scales with fully developed wings. The female insects, on the other hand, remain beneath the scale coverings throughout their lives, depositing eggs under the shells in the fall before they die. There is apparently only 1 generation a year in the Pacific Northwest.

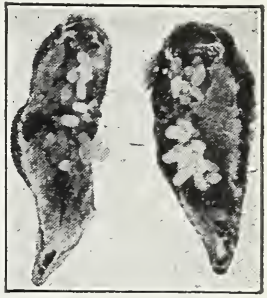

FiguRe 11.- Inverted scales showing eggs of the oystershell scale. $\times 9$.

\section{CONTROL}

The dormant-season application of lime-sulfur solution is not so effective against the oystershell scale as against the San Jose scale.

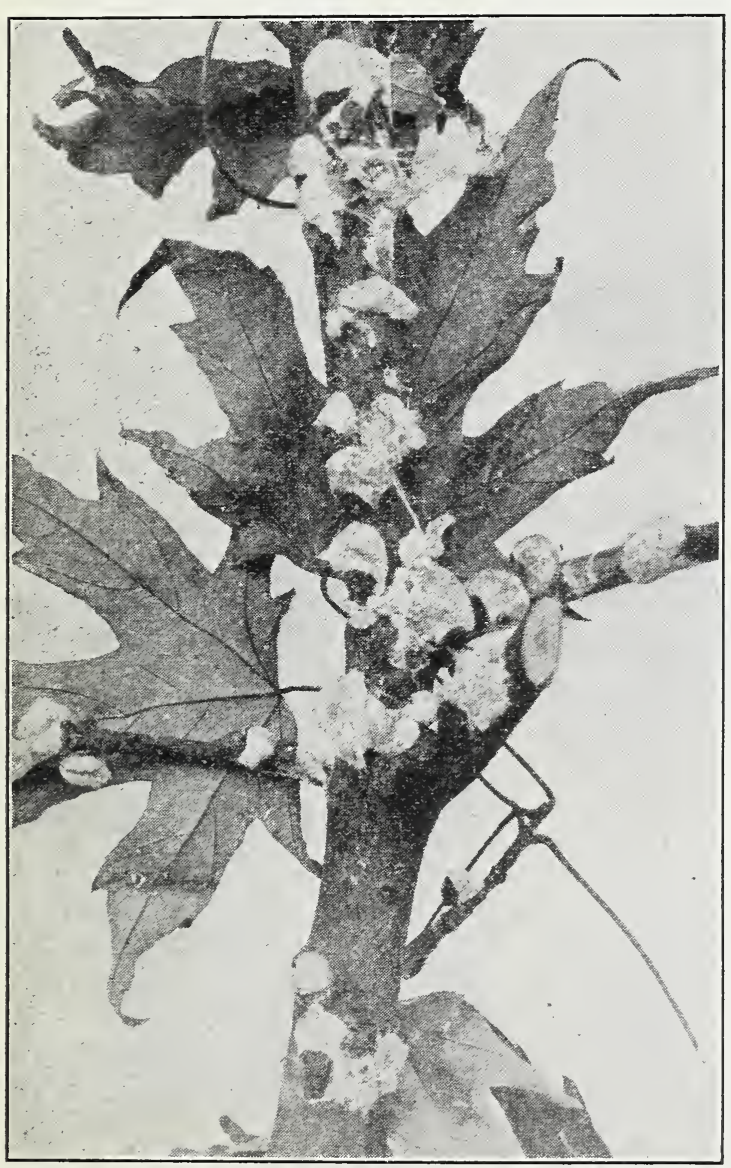

Figure 12.-Cottony maple scale on maple twig. $\quad \times 2$.

However, the regular annual use of the solution keeps the insects fairly well in check. Oil emulsions, at the dilu$\mathrm{t}$ ion s recommended for dormant spraying (p. 73), are more effective and should be used for severe infestations. Summeroil emulsion, containing 2 percent of oil, applied just after the eggs have hatched is effective in killing the young scales, but this cannot be used safely if limesulfur solution has been applied within 2 months.

\section{Cottony Maple Scale}

The cottony maple scale (Pulvinaria vitis (L.)) sometimes becomes quite common on Winter Nelis and Anjou pear trees, but does not seem to thrive on the Bartlett va- 
riety, and is very seldom seen on apple trees. It is primarily a pest of maple trees (fig. 12), as its name indicates, and also lives on grape, boxelder, blackberry, and a variety of other plants. It is a native of Europe, and came to the United States over 100 years ago. The insect is easily recognized by the cottony egg sac which the female produces in the early summer, and which often remains for some time. About 3,000 eggs are laid in this sac, and these hatch during June and July. The young scales settle on the undersides of the leaves, where the male insects

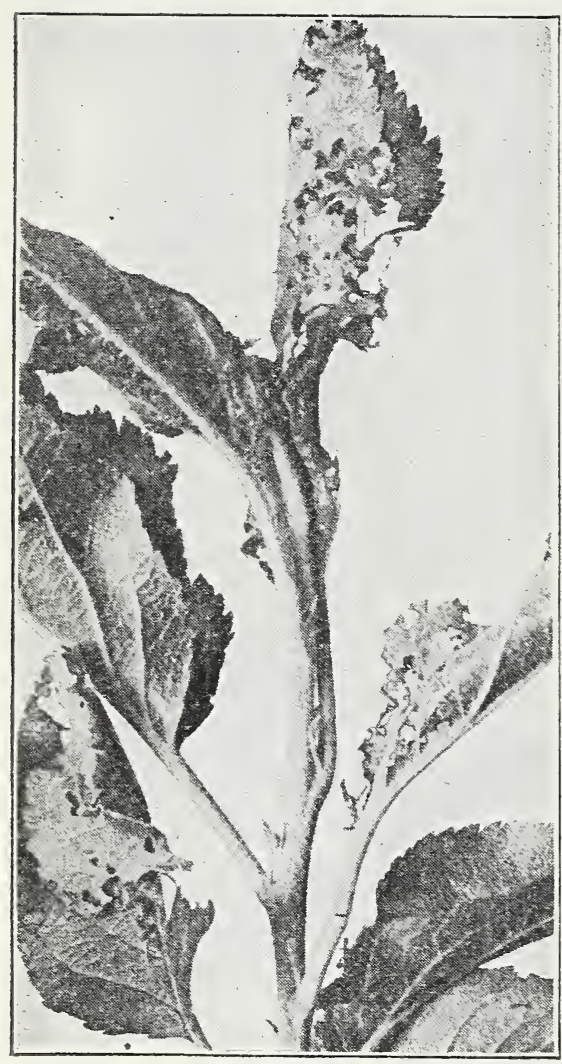

Figure 13.-- Leaf roller injury to apple foliage. mature. The partly grown females, which are oval, flattened, and greenish or yellowish, migrate to the twigs in the fall and hibernate there. They complete their growth in the spring, when they are brown, quite convex, and about one-eighth inch in diameter. The egg sac is formed gradually, as the eggs are laid, and the females die when oviposition is complete. There is only 1 generation in a year.

Applications of oil emulsion or lime-sulfur solution during the dormant season, as recommended for the San Jose scale, control this insect very well. In July, after the young have settled on the leaves, they may be killed with nicotine sulfate (40 percent nicotine) in the proportion of three-fourths of a pint to 100 gallons of water, to which is added 2 or 3 pounds of soap dissolved in water, or 1 pound of casein spreader. This spray mav often be combined with an application for the codling moth.

\section{Fruit Tree Leaf Roller}

The fruit tree leaf roller ( $\mathrm{Ca}$ coecia argyrospila (Walk.)) feeds primarily on the fruit and foliage of tne apple, but also on those of most of the other deciduous fruit trees. The small caterpillars, hatching when the buds begin to open, feed on the unfolding leaves, webbing them together and forming a protection for themselves (fig. 13). This webbing often covers the blossom buds, causing considerable injury by preventing normal blooming. As the caterpillars become larger, they roll up one or more large leaves and include some of the fruit in the webbing, making a sort of nest. They feed within this, eating large, irregular holes in the fruit (fig. 14) and foliage. In extreme cases they practically defoliate the trees and cause a total crop loss. In regions where much spraying is done for the codling moth and the San Jose scale 
the fruit tree leaf roller has not been an important pest, but occasional very serious outbreaks have occurred elsewhere, and may occur again. In the past the insect has periodically become of prime importance, remained so for a few years, and then again subsided into relative unimportance. It is a native insect which originally fed on the foliage of a number of wild plants.

\section{LIFE HISTORY}

The fruit tree leaf roller passes the winter in the egg stage. The eggs (fig. 15) are laid in masses of 100 or more, and are rather inconspicuous, oval, grayish or brownish patches, nearly onefourth of an inch long, on the limbs, twigs, and trunks of the trees. The eggs hatch as soon as the buds begin to open. The caterpillars gnaw small holes in the surface of the egg mass, through which they escape, and hatched egg: masses may be identified by these perforations. The caterpillars are quite active, crawling backward about as rapidly as forward, and often letting themselves to the ground on a thread if disturbed. They become full-grown in June and at that time are about threefourths of an inch long, and are green with black heads.

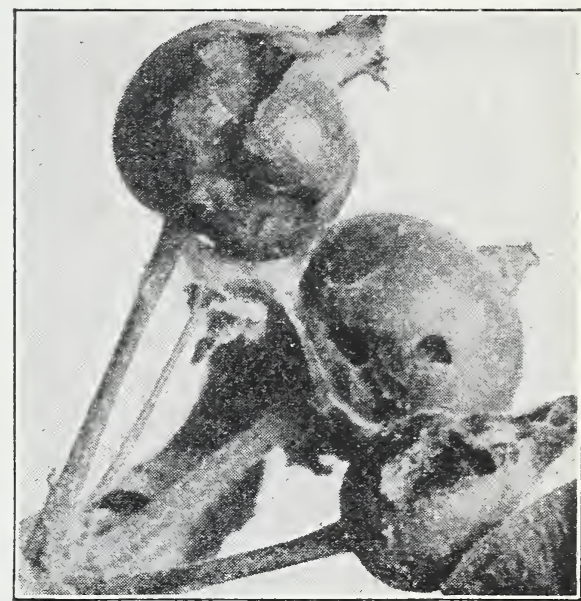

Figure 14.-Fruit eaten by larvae of the fruit tree leaf roller. They transform to brown pupae in the rolled-up leaves, and the moths (fig. 16) emerge about 10 or 12 days later. These are a little larger than codling moths, the expanded wings measuring about three-fourths of an inch across. They are cinnamon brown, with 2 or 3 light-yellowish

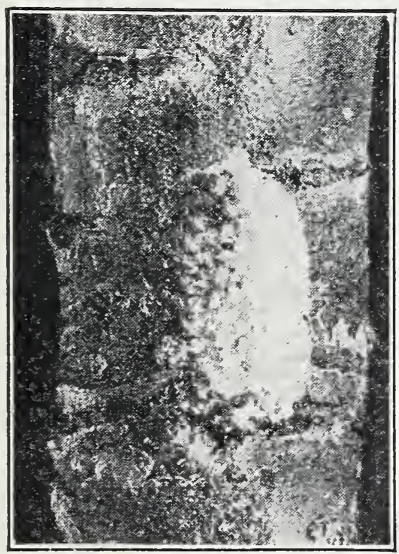

Figure 15.-Egg mass of fruit tree leaf roller.

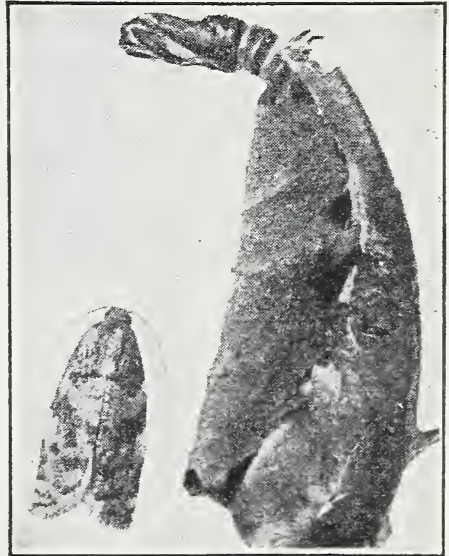

FIGURE 16.--Fruit tree leaf roller cocoon, pupal skin, and moth. About $\times 2 \frac{1}{2}$. 
markings. The eggs are laid during June and July, each female depositing all of her eggs in a single mass, unless disturbed. These eggs hatch the following spring.

\section{CONTROL}

The most effective means of controlling the leaf roller is by destroying the eggs with an oil spray in the spring before they have hatched. Any of the emulsions that are satisfactory for scale control may be used for this purpose. Light infestations may be treated with an emulsion containing 4 percent of oil, as this kills most of the eggs, but for serious outbreaks, when large numbers of eggs are on the trees, the strength of the dilute emulsion should be increased so that it contains 5 or 6 percent of oil. Spraying should be done during the first settled period of mild weather. It should not be done just before a. rain or when temperatures lower than $25^{\circ} \mathrm{F}$. are likely to occur within a few days, as there is danger of injury to the trees under those conditions. Neither should it be delayed until the eggs hare begun to hatch. Serere infestations that hare not been sufficiently controlled by this means may sometimes be lessened by the use of lead arsenate in the proportion of 4 pounds to 100 gallons of spray just at the time the buds begin to separate in the clusters.

\section{Red Spiders}

Red spiders or mites do great damage to apple and pear trees, much of it difficult to measure. They feed by withdrawing the contents of the leaf cells, including the chlorophyll, thus causing a whitening or mottling of the leaves. Apparently this chlorophyll is not replaced. Apple foliage usually becomes browned or bronzed as a result of mite attacks. In irrigated orchards the leares seldom drop, but in nonirrigated orchards complete or partial defoliation frequently results. Pear foliage is affected in somewhat the same way as apple foliage. The leares, particularly on Anjou, Winter Nelis, and Bosc, often brown and dry up during the first extremely hot weather in the summer. While this condition is probably due chiefly to the inability of the tree to supply moisture fast enough during the sudden onset of hot weather, it may be aggrarated by a severe infestation of mites, since they remove large quantities of moisture from the leares. As the trees manufacture their food supply largely in their leares, any foliage injury will reduce the vitality of the tree, and consequently the size of the fruit, eren if it does not cause the leares to drop off.

\section{LIFE HISTORY}

There are three species of orchard-infesting red spiders in the Pacific Northwest. These

FIGURE 17.--Pacific mite: $A$, egg; $B$, adult. $X$ 61. differ somewhat in their habits, and somewhat different methods must be used to control 


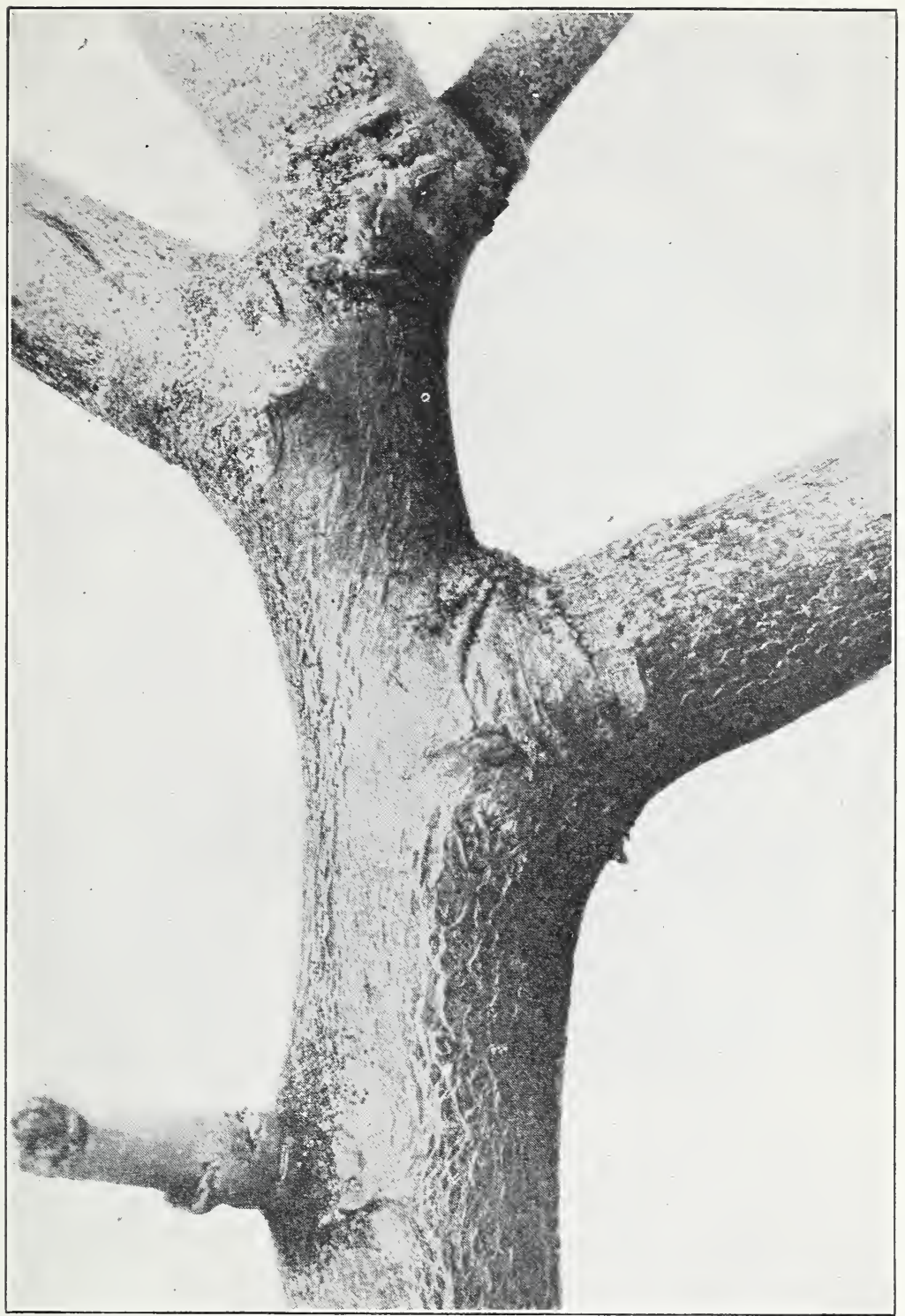

FIGURE 18.- Overwintering eggs of the European red mite. About $\times 21 / 2$.

them. Two are of European origin and the other is native.

The Pacific mite (Tetranychus pacificus McG.) ${ }^{5}$ (fig. 17) causes more injury than the other mites occurring in the Pacific Northwest, and in some orchards it is the most serious pest that the grower has to deal with. It may be recognized most easily by the quantity of webbing it spins, which often collects dust and gives the foliage a

${ }^{5}$ This species has been confused with the common red spider or two-spotted mite ( $T$. telarius (L.)). A closely related species ( $T$. willamettei $\mathrm{McG}$.), having similar habits, is prevalent on apple and pear in the Hood River and Rogue River Valleys of Oregon. $291255^{\circ}-41-3$ 
very dry and dusty appearance. This species passes the winter in the adult stage in leaves and trash on the ground, and in mild winters some individuals are able to survive on the trees in crevices of the bark. In the spring the mites migrate into the trees, first attacking the foliage nearest the ground and gradually extending their operations to cover the whole tree. The mites are usually greenish or yellow-

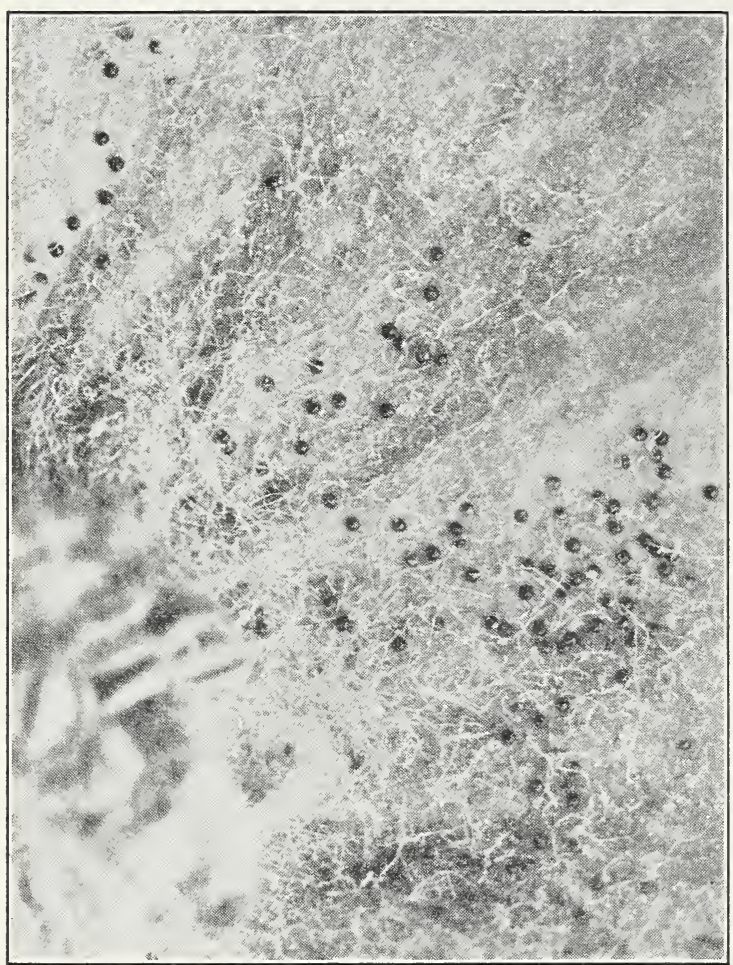

FIGURE 19.- Overwintering eggs of the European red mite in calyx end of apple. $\times 12$. ish while feeding, often with two dark spots on the body. The eggs, which are almost colorless, are laid in the webbing. The young are similar to the adults in appearance, except that they have six legs instead of eight. They develop from egg to adult in a week or 10 days, and there are several generations in a year, which makes it possible for the mites to become exceedingly numerous in one season. Late in July or in August, particularly if the infestation is severe and the mites are crowded, many of the adults cease feeding, become reddish or orange, and migrate to their hibernating places. Since this migration is downward, many of them collect around the calyx ends of apples, where they spin a great deal of webbing which takes on the appearance of cellophane. This species thrives on a variety of fruit trees and also occurs on a milkweed (Apocynum) which grows in the orchards, but it is especially injurious to apple.

The European red mite (Paratetranychus pilosus (C. and F.)) lays bright red overwintering eggs on the twigs and branches of fruit trees (fig. 18), and when these eggs are numerous they are very noticeable as reddish patches on the bark. They are also found in the calyx end of mature apples (fig. 19). These eggs hatch in April just before the blossoms open. The mites feed on the foliage, usually on the underside and spin very little webbing. They are more easily seen than the Pacific mite, being velvety or brownish red, with conspicuous, whitish, curved spines on the back. During the summer the eggs are laid on the leaves, and there are seven or eight generations in a season. This species is very seldom found on anything except deciduous fruit trees. 
The brown mite or clover mite (Bryobia praetiosa Koch) (fig. 20) also passes the winter in the egg stage, the eggs being very similar to those of the European red mite and not distinguishable from them with the naked eye. They hatch at about the same time in the spring, and the habits and life history of the two species are much alike. The brown mites spin no webbing and usually congregate in roughened places on the twigs and branches during the day, migrating to the leaves at night to feed. This habit of feeding at night and the lack of webbing make them rather inconspicuous, and their presence is usually first noted because of the whitening of the leaves caused by their feeding. The adult mites are dull reddish or greenish, and are flatter and have longer legs than the European red mites. They are found on deciduous fruit trees and on clover and other forage crops.

\section{CONTROL}

The method of controlling. red spiders, as already stated, depends on the species involved. The overwintering forms of the Pacific mite sometimes can be reduced by proper cultivation, or by burning the leaves and trash in which they are hibernating. Irrigation, where practiced, is an important factor

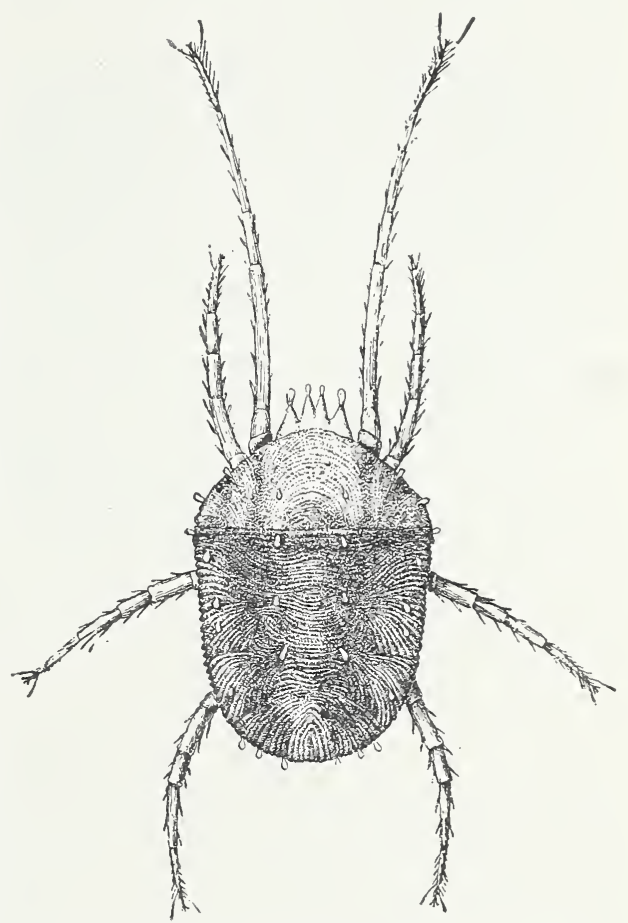

FIGURE 20.-Adult clover mite. $\times 45$. in reducing red-spider injury and in facilitating control by spraying. Thrifty, adequately irrigated trees will not suffer nearly so much as those that are dry and in poor condition. This is important, as defoliation is always serious if it occurs before September. It may force the trees to send out new leaves or blossoms in the fall, materially reducing the following year's crop, and it affects the fruit buds and the size of the current year's crop.

Spraying is practically the only direct means of control for red spiders. It must be done before July to be of much value. If spraying is delayed until after that time, the mites often become so numerous that adequate control is impossible. Dormant-season sprays, containing 4 percent of oil emulsion, as used for scale insects or for the leaf roller, are very effective in destroying the overwintering eggs of the European red mite and the brown mite. The oil should be applied before March 15, if possible, as the trees are sometimes injured by late-dormant oil sprays. Lime-sulfur solution is relatively ineffective against these eggs. Sprays of lime-sulfur solution, however, with 2 or 3 gallons of the concentrate to 100 gallons of water, as used for 
combating powdery mildew or scab (table 1, p. 71 ), are valuable in destroying the young mites. These sprays should be applied just before the blossoms open and again as a calyx application.

It is often necessary to use lime-sulfur solution in the dormantseason application on account of the presence of other insects that are best combated with that material. If such insects are on the trees, or if the mites hare not been otherwise controlled, a very effective measure consists in using oil in one or more of the summer sprays. The treatment may be combined with that for the codling moth by simply adding 1 to $1 \frac{1 / 2}{2}$ gallons of a standard summer-oil emulsion to 100 gallons of the lead arsenate spray. Preferably this should be done before July, unless previous applications of lime-sulfur solution make it inadrisable. Oil should not be used in summer sprays less than 60 days after a lime-sulfur application, because of the danger of burning the foliage.

Summer treatment is necessary for the Pacific nite, since this species is usually not on the trees when the earlier sprays are made. Lime-sulfur solution in the "pink" spray at 2 or 3 gallons of the concentrate to 100 gallons of water, followed by colloidal or elemental sulfur at 3 to 5 pounds to 100 gallons added to the calyx and first corer sprays as applied for the control of the codling moth, constitutes the most effectire control for this mite. This is because the sulfur collects in the webbing and the fumes kill the mites running about in it, including the young as they hatch. Sulfur is much less effective against those species that do not spin webs.

Summer spraying for red spiders must be extremely thorough, as the spiders infest the entire tree, and portions not sprayed often harbor enough spiders to reinfest the tree in a short time.

\section{Pear Leaf Blister Mite}

The pear leaf blister mite (Eriophyes pyri Pgst.) lives in the buds, foliage, and fruit of apple and pear trees. It produces small galls or

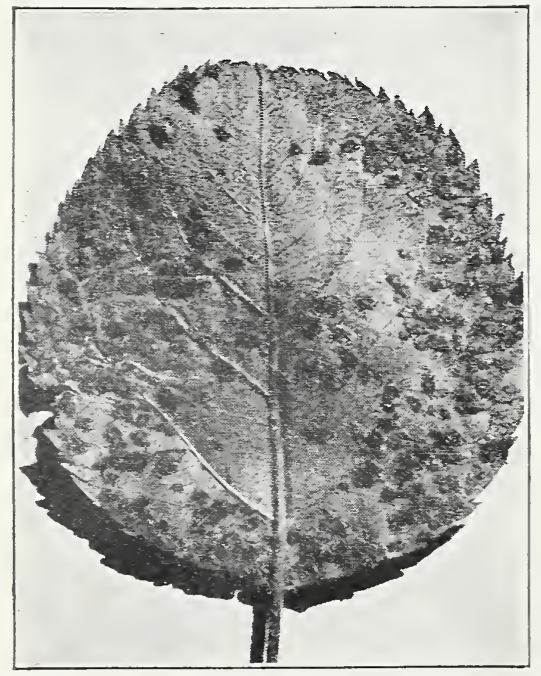

FIGURE 21.-Apple leaf infested with pear leaf blister mite. blisters on the leaves. At first these galls are greenish or reddish, but later turn brown and cause dead areas. These areas may have an appearance similar to that of apple scab but may always be identified by the small round hole which will be found on the under surface of the leaf approximately in the center of each blister (fig. 21). Since the mites begin feeding in the leares before these are fully opened, the new leares show the blisters at once; and if the mites are numerous, many of the leares later dry and drop off. The fruit of the apple is more seriously affected than that of the pear; it is attacked when it is young, and the injuries cause mature fruit to be russeted or deformed (fig. 22) and some- 
times to crack open. The mites also injure and deform the blossoms. There is some evidence that the mites attacking apple and pear are distinct species, since very often one fruit shows evidence of injury, while on adjacent trees the other fruit does not. The mite that attacks the apple apparently comes from the wild snowberry (Symphoricarpos racemosus Michx.), since a mite that seems to be identical is found on that plant, and infested apple orchards are most often in canyons and along: foothills adjacent to wild growths of the snowberry. The form found on the pear tree is evidently the same as the species occurring in Europe, and undoubtedly came from there originally.

\section{LIFE HISTORY}

The adult mites pass the winter under the scales of fruit

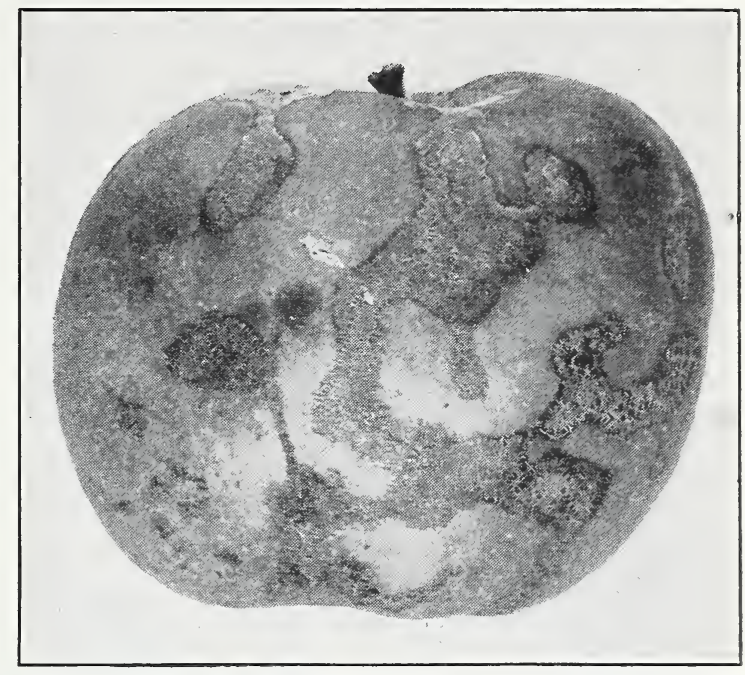

Figure 22.-Apple deformed and russeted by pear leaf blister mite. and leaf buds. They are exceedingly small, less than one one-hundredth of an inch in length, and are therefore practically invisible to the naked eye. Under a lens or a microscope they appear (fig. 23) as elongated, whitish, wormlike creatures, with four legs near the head end. Often hundreds of them can be found in a single bud. When the buds begin to swell under the influence of warm spring weather, the mites lay eggs in them, and the young hatching from the eggs burrow into

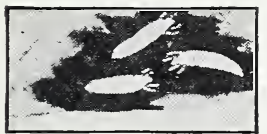

FIgURE 23.-Adults of the pear leaf blister mite. $\times 40$. the unfolding leaves and form the characteristic blisters. The mites feed entirely within the blisters, and a succession of generations develops, practically out of the reach of sprays. With the approach of cold weather the mites migrate to the buds, beneath the scales of which they hibernate.

\section{CONTROL}

The pear leaf blister mite can be controlled very easily with limesulfur solution used as a dormant spray at the same strength as for the San Jose scale; that is, a solution testing $4 y_{2}^{\circ}$ Baumé (table 1 , p. 71). If the San Jose scale is not present, the solution need test only $3 \frac{1}{2}$ Baumé. Spraying should be completed in the spring before the buds have begun to open, for the mites get into the leaves soon after that and cannot be reached with the spray. Good control may also be obtained by spraying in the fall, as soon as the leaves have dropped. Oil emulsions are not very effective unless applied just as 
the buds are swelling noticeably, and the weather must be warm at the time in order to allow the oil to penetrate into the buds and kill the mites.

\section{Rust Mite}

A very small mite, not unlike the pear leaf blister mite, is often found on the under surfaces of apple and pear leaves as well as on prune leaves. This is the rust mite (Phyllocoptes schlechtendali Nal.), so named because its feeding usually produces a rusty appearance on

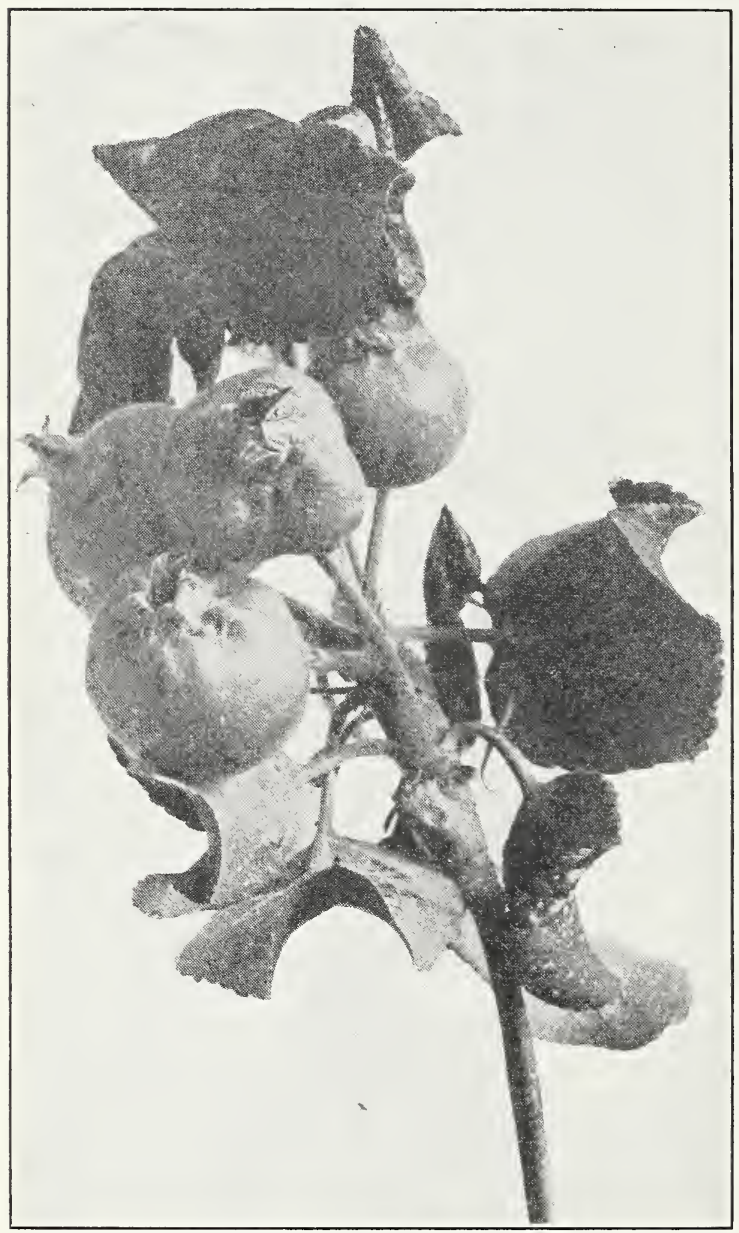

Figure 24.-Apples stunted by the rosy apple aphid. the leaves. It also causes the leaves to roll longitudinally. At times the fruit also is attacked and may become russeted. The mite itself is slightly smaller than the blister mite and can scarcely be seen with the naked eye. Under a lens it is found to be somewhat shorter and more triangular in shape than the blister mite. Instead of producing blisters, this mite feeds on the leaf surface during the growing season and hibernates in the buds. It may be controlled by the same means used for the blister mite; and since it is exposed during the summer, sulfur or oil sprays applied during that time will also effect control if care is used to spray the undersides of the leaves very thoroughly.

Rosy Apple Aphid

The rosy apple aphid (Anuraphis roseus (Baker)) curls the leaves, particularly those on the fruit spurs, and infests the young fruit, causing it to become stunted and distorted (fig. 24). These "aphid apples" do not thin out normally during the "June drop" and clusters of them are often conspicuous in the fall, especially on the lower and inner parts of the trees. At times they are sufficiently numerous to cause a distinct reduction in the marketable crop. This aphid was probably introduced from Europe. 
It feeds only on apple and on its alternate summer host, the plantain or ribgrass.

\section{LIFE HISTORY}

The aphid passes the winter in the egg stage on apple trees, and the eggs hatch in the spring when the buds begin to swell appreciably. The young start feeding in the unfolding fruit buds, causing the leaves to curl as they develop. Several generations are produced on the apple, and these feed on the leaves and the fruit. Tightly curled leaves often contain hundreds of the characteristically purplish or rosy-brown aphids, and the species may be distinguished readily by its color and by its habit of curling the leaves and deforming the fruit. As the weather becomes warmer, brownish-green, winged individuals develop and migrate to the plantain. Most of the aphids have left the apple by early in July. Migration to other apple trees does not occur, and trees not bearing winter eggs remain free of infestation. On the plantain several generations of yellowish-green aphids occur, and in the fall winged forms again develop and fly back to the apple trees, where they produce a wingless generation of aphids which deposit winter eggs on the twigs, in the axils of the buds, and in crevices in the bark. These eggs are at first pale green but later become shiny black.

\section{CONTROL}

Control of the rosy apple aphid should be effected before the leaves have been curled, as it is very difficult to accomplish afterward. As aphids are sucking insects, contact insecticides rather than poisons must be used. A spray containing 4 percent of oil destroys a great many of the young aphids that are gathered on the buds if it is applied just after the eggs have hatched. The dormant-season application of lime-sulfur solution is relatively ineffective. More thorough control will result from using nicotine sulfate (40 percent nicotine) in the proportion of three fourths of a pint to 100 gallons of water, in combination with the oil emulsion or the lime-sulfur solution. This application must be completed before the tips of the leaves have begun to separate (fig. 25 ).

\section{Apple Aphid}

The apple aphid (Aphis pomi Deg.), formerly known as the green apple aphid, lives on apple trees throughout the year and feeds mostly on the succulent terminal twigs (fig. 26), curling the leaves and stunting the growing shoots. It is thus injurious chiefly to nursery stock and to young trees, although it sometimes becomes sufficiently numerous on bearing trees to hinder normal growth. It is occasionally found on pear trees. This aphid, which came from Europe, is now found in the United States wherever apples are grown.

\section{LIFE HISTORY}

This aphid passes the winter in the egg stage, in the same manner as the rosy apple aphid, although the eggos are more likely to occur on water sprouts. The eggs hatch at about the same time as do those of the rosy apple aphid, and there may be from 9 to 17 generations in a 
year. Young and adults are green, with black legs, and often with yellowish heads. Some of the adults are winged, and these migrate to other apple trees, thus spreading the infestation during the season. The eggs are green when deposited in the fall, but later become glossy black.

\section{CONTROL}

The control measures recommended for the rosy apple aphid are also effective for this species. Since it remains on the trees throughout the season and migrates from tree to tree, additional sprays may be necessary, particularly on young trees or on nursery stock. Threefourths of a pint of the nicotine sulfate, to which is added 2 or 3 pounds

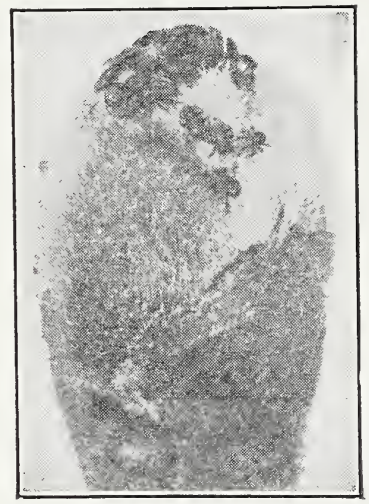

FigURe 25.-Proper stage at which to spray for aphids.

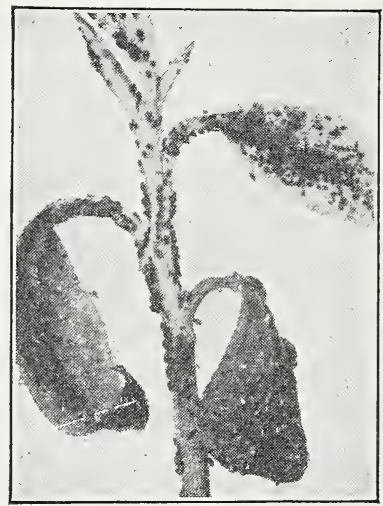

Figure 26.-Apple aphids on apple foliage.

of soap in solution or 1 pound of casein spreader to every 100 gallons of spray, is very effective if applied thoroughly in order to reach the aphids in the curled leaves. In hot weather, when the temperature is above $80^{\circ} \mathrm{F}$., the quantity of nicotine sulfate may be reduced to one-half of a pint to 100 gallons, as nicotine is more effective in hot weather than in cool weather. If bearing apple trees are to be sprayed, this application may be combined very effectively with a summer oil emulsion and used in place of one of the regular applications of lead arsenate for the codling moth.

\section{Woolly Apple Aphid}

The woolly apple aphid (Eriosoma lanigerum (Hausm.)) attacks the roots as well as the upper parts of the trees. Above ground it is found chiefly on the trunks, limbs, and twigs, in wounds caused by pruning or cultivating implements, and wherever the bark is tender (fig. 27). Twigs become somewhat swelled and knotted as a result of its attacks. The aphids are occasionally found on the fruit stems and in the calyx ends of apples. Injury to the roots is not very important in the arid, sandy areas of the Northwest, and in those areas it is more or less limited to exposed roots. In the coastal sections, particularly in heavy soil that may crack, the aphids penetrate to the roots, causing 
swellings and deformities (fig. 28) that may result in severely hindering the growth of the tree. The colonies of aphids appear as bluishwhite, woolly patches, which are composed of the reddish insects covered with woolly masses of wax. When the aphids are numerous this waxy material, which contains some honeydew excreted by the insects, hangs in festoons, smears the fruit, and makes picking a disagreeable job. The aerial form also apparently prevents healing of cankers caused by the perennial canker, in districts where that disease occurs. The woolly aphid is found in practically all apple-growing districts.

\section{LIFE HISTORY}

The life history of the woolly apple aphid in the Pacific Northwest appears to be somewhat diferent from that in the East, where wintering eggs are laid on the elm trees. In the West this habit has not been observed, but roots of the apple trees, and many

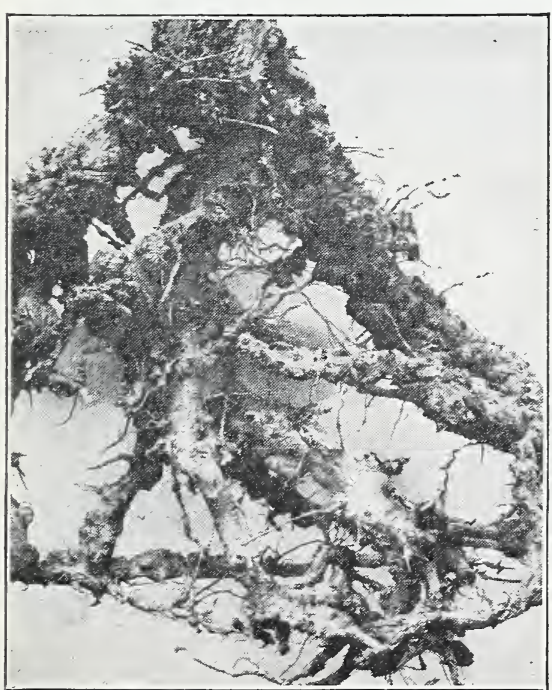

FIGURE 28.-Nodular roots resulting from attack by the woolly apple aphid.

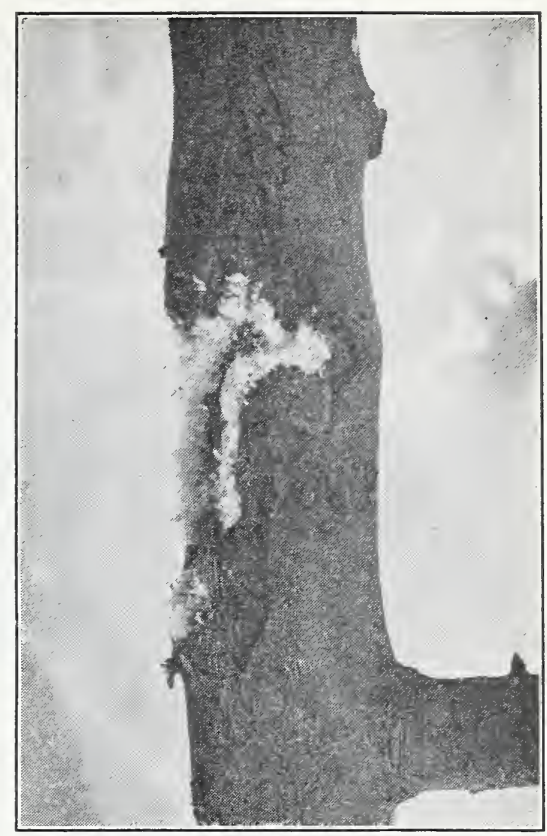

FIGURE 27.-Aerial colony of the woolly apple aphid.

wingless forms hibernate on the of those on the upper portions of the trees survive mild winters. Infestations above ground may thus come from wintering forms already present there or from migrants from the roots. Heavy infestations are likely to follow mild winters. The aphids multiply rapidly, and winged forms occur at times, which may fly to other apple trees and establish new colonies; and this may also be accomplished by young aphids which are carried from tree to tree by the wind or by other means.

\section{PREVENTION AND CONTROL}

The successful establishment of the woolly aphid parasite Aphelinus mali Hald.in the Pacific Northwest now makes it unnecessary to use sprays for its control in many orchards. The presence of many swollen and blackened aphids (fig. 81 ) is evidence that the parasite is gaining control over the aphid. However, if the aphids become 
numerous on the twigs and branches, and control is desired, a contact spray, such as nicotine sulfate (40 percent nicotine) in the proportion of three-fourths of a pint to 100 gallons of water, added to an oil emulsion, or used with soap or casein spreader, is effective.

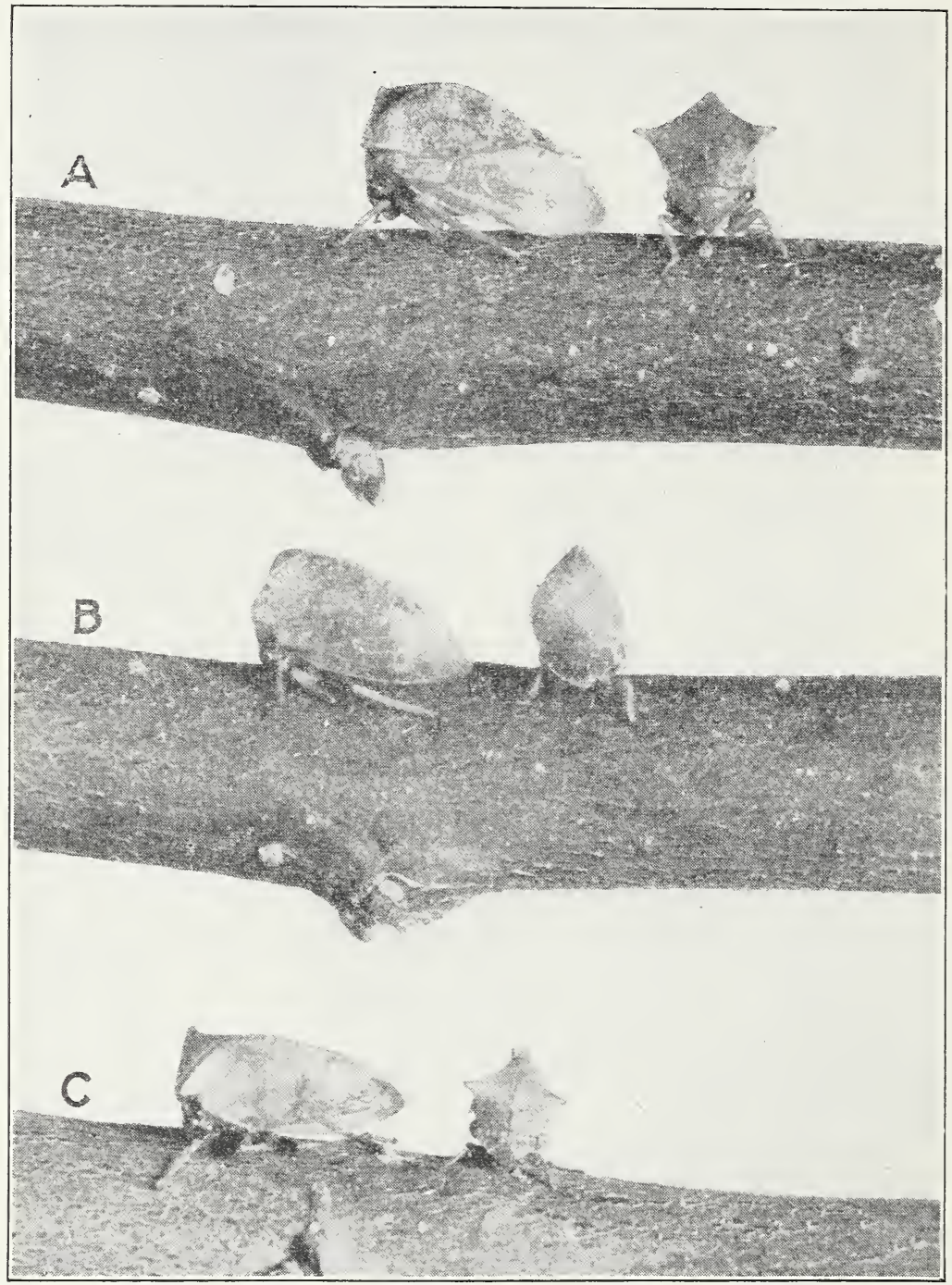

Figure 29.-A, Buffalo treehopper; B, green clover treehopper; C, dark-colored treehopper. $\times 3$.

If used with an oil emulsion, this spray may replace one of the lead arsenate sprays in the schedule for controlling the codling moth. On account of the protection afforded the insects by their woolly covering, the spray must be applied very thoroughly and with adequate pressure. The oil emulsion alone is not effective. 
Control of the woolly aphid in cankers caused by the perennial canker is not always accomplished by the usual sprays. The Oregon Agricultural Experiment Station has recommended trimming out all cankered bark early in the summer, allowing the wounds to heal 10 to 14 days, and then applying (with a brush or a paint gun) a mixture of 1 part of nicotine sulfate (40 percent nicotine) and 6 parts of tree paint. The wounds should be repainted annually. Information about tree paint may be secured from the Oregon Agricultural Experiment Station.

Control of the aphids on the roots is extremely difficult. The most practical method is to keep the trees in a thrifty, vigorous condition, by means of proper cultivation and fertilization, so that they can withstand the drain caused by these insects. Applications of tobacco refuse about the roots, fumigation with carbon disulfide, and other remedial treatments have been tried, but are not always successful. Paradichlorobenzene, recommended for controlling the peach borer, has been used with some success for the woolly aphid, particularly on old trees. It should be applied in the same manner as for the peach borer (p. 55), at any time during the summer or fall, at the rate of $3 / 4$ to 1 ounce per tree.

\section{TREEHOPPERS}

Young orchards containing alfalfa or clover cover crops are subject to the attacks of several species of treehoppers, among which the buffalo treehopper (Ceresa bubalus (F.)), the green clover treehopper (Stictocephala

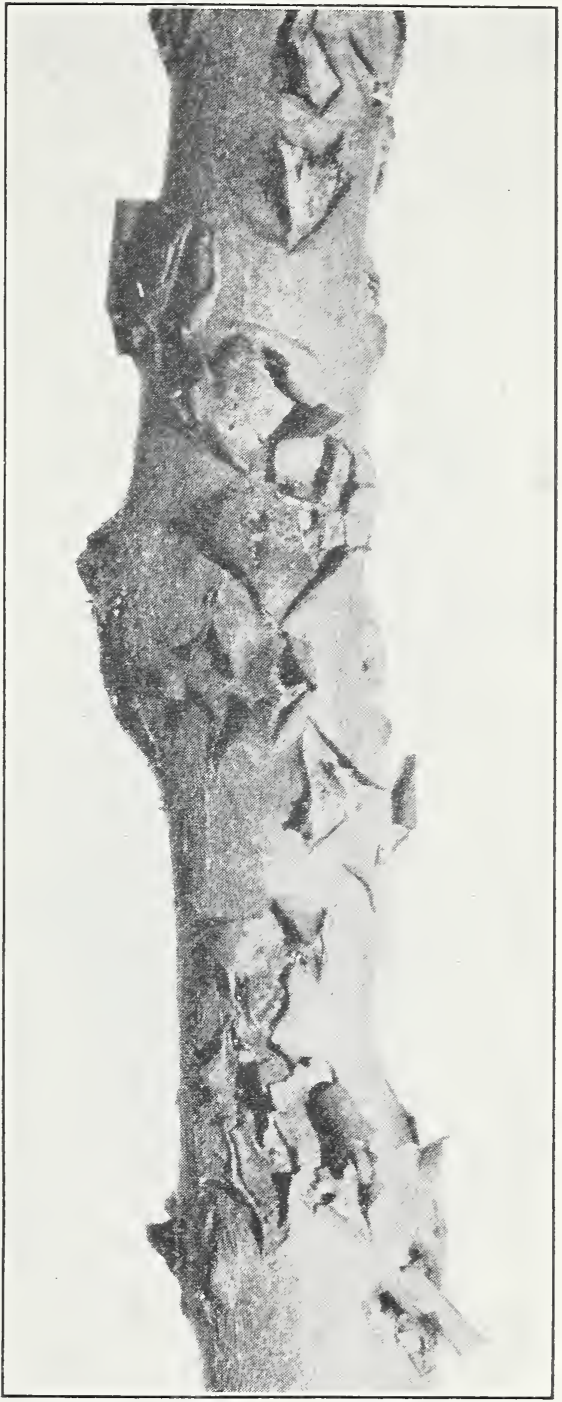

FIGURE 30.-Apple twig scarred by green clover treehoppers in laying eggs. $\times 3$. inermis (F.)), and the dark-colored treehopper (C. basalis Walk.) (fig. 29) are the most injurious. The injury is caused by the wounds and scars made by the female in laying her eggs in the bark of the trees (fig. 30). These scars are cut by the female with her ovipositor, and may be roughened and ragged or clean-cut, longitudinal slits, depending on the species making them. The injury rarely extends 
more than 6 or 8 feet above the ground, and young trees are most often attacked. Frequently the growth of such trees is seriously retarded. Injury is practically confined to the current season's growth and to 1-year-old wood, but the old scars persist for some years. Apple and pear trees are the most subject to injury, although peach, cherry, plum, and quince are occasionally affected.

\section{LIFE HISTORY}

The whitish, cylindrical eggs of the treehoppers are about onetenth of an inch long, and from 6 to 20 of them are placed side by side

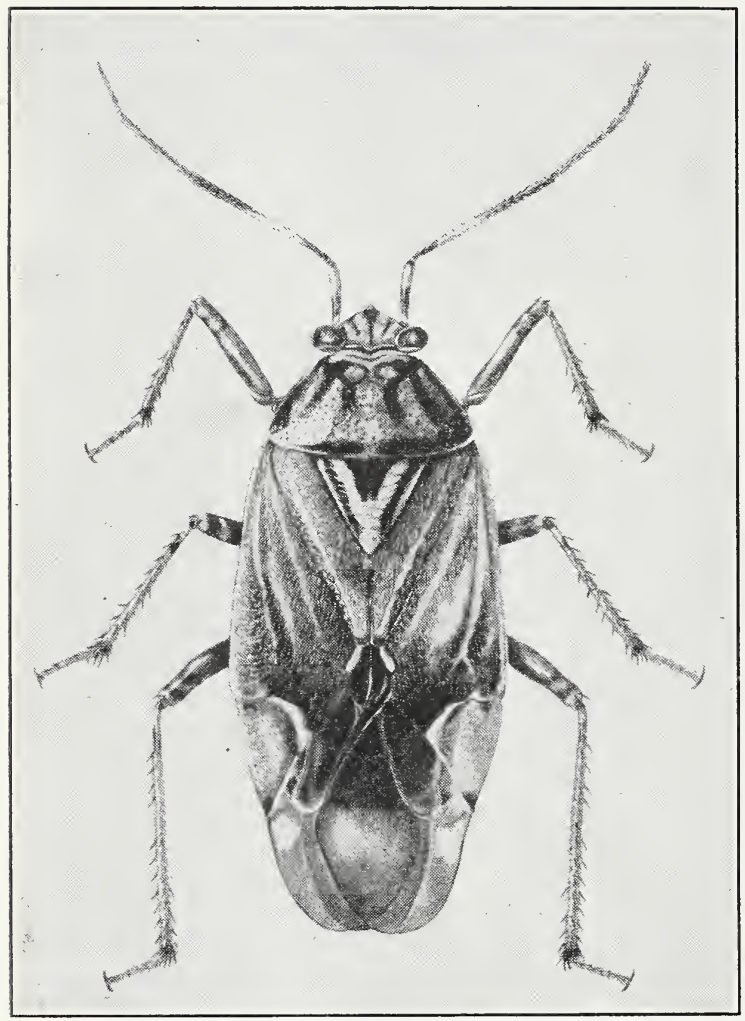

FIGURE 31.-Tarnished plant bug. $\quad \times 12$. in each slit, the ends usually being visible. They are deposited during the period from July to September and hatch the following April or May. 'The young, or nymphs, drop to the ground and feed chiefly on alfalfa, where they are most often found in the center of the crowns. Growth is completed in July. The adult insects are about three-eighths of an inch long, grayish or greenish, and triangular, and the commoner species have projecting pronotal horns, suggesting the appearance of a buffalo.

\section{CONTROL}

Clean cultivation is the most obvious and practical control method and should be practiced in young orchards whenever possible. As the trees bec $^{0}$ me older, cover crops may be planted, for the injury is less severe on older trees. Many of the worst-scarred twigs can be pruned off during the winter, and should be burned to destroy the eggs. A thorough dormant spray containing 4 percent of lubricating-oil emulsion kills most of the eggs in the twigs and may reduce the infestation the following year.

\section{Tarnished Plant Bug}

The tarnished plant bug (Lygus oblineatus (Say)) (fig. 31) appears in the trees early in the spring and punctures the swelling fruit and leaf buds (fig. 32), sucking the sap from them. Its presence is often first 
made known by the brownish drops of sap exuding from these punctures. This loss of sap causes the buds to dry, and in the case of fruit buds the blossoms may never open, or, if they do, they may be deformed. When the bugs are sufficiently numerous, the injury is severe (fig. 33) and may result in almost a total failure of the crop. The degree of injury is contingent not only on the number of bugs, but on weather conditions. Continued periods of settled warm weather in March or early in April, coming before alfalfa and other ground crops have developed, cause the bugs to feed in the trees; cold, rainy, or windy weather at this time prevents extensive feeding. Pears and Delicious apples are the most susceptible to this injury. The bugs also sometimes feed on the young (fig. 34) and maturing fruit and cause dry or corky and sunken spots. The tarnished plant bug occurs throughout the Northern Hemisphere; its origin is uncertain.

\section{LIFE HISTORY}

The adult tarnished plant bugs are nearly one-fourth of an inch long, dirty grayish or greenish, with variable markings. They come out of hibernation during the first warm, sunny days of early spring and feed for a time on fruit-tree buds, and the leguminous cover crops. They are quite active, flying readily or moving around to the opposite side of a twig or bud when approached, and are not easily seen. Eggs are laid in the tender shoots or in the flower heads of a number of plants, and the nymphs, which resemble the adults, except that they are smaller and have no wings, feed chiefly on cover crops and weeds. Growth is attained in less than a month, nymphs going through a series of molts as they increase in size. There are three or four broods during the season, and the bugs are often very numerous in the fall. Large numbers of these bugs die when the first

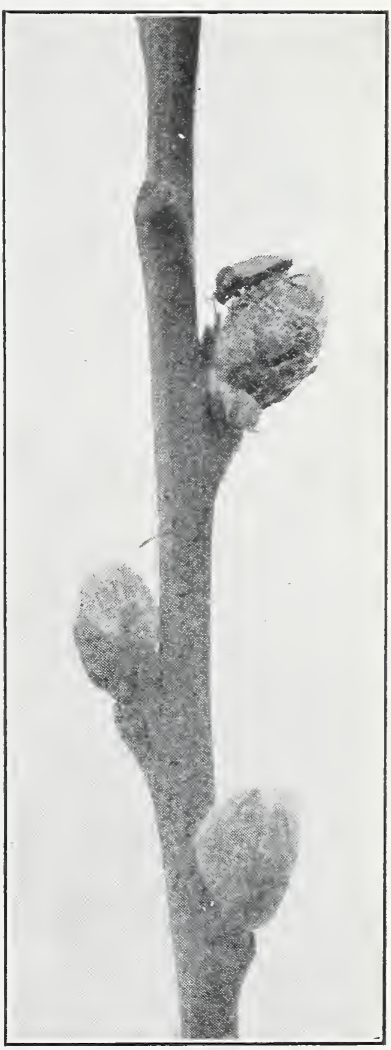

Figure 32 -Tarnished plant bug feeding on peach bud. $\times 2$. cold weather comes and the mortality among those hibernating is apparently high.

\section{CONTROL}

No very satisfactory method of controlling the tarnished plant bug has been devised. Something can be accomplished by cleaning up and burning trash which may accumulate about buildings, and burning grass and leaves along fence rows. Burning should be done during cold weather in order to destroy the bugs before they can escape. It must be done with great care about orchards, as trees are very easily injured by fires near them, and fires sometimes escape into the orchards themselves. Destruction of trash in the orchard by this means is not advised, for the trash usually forms part of the orchard mulch 
and should not be burned. Thorough cultivation late in the fall may be of some benefit, covering the bugs with soil and preventing

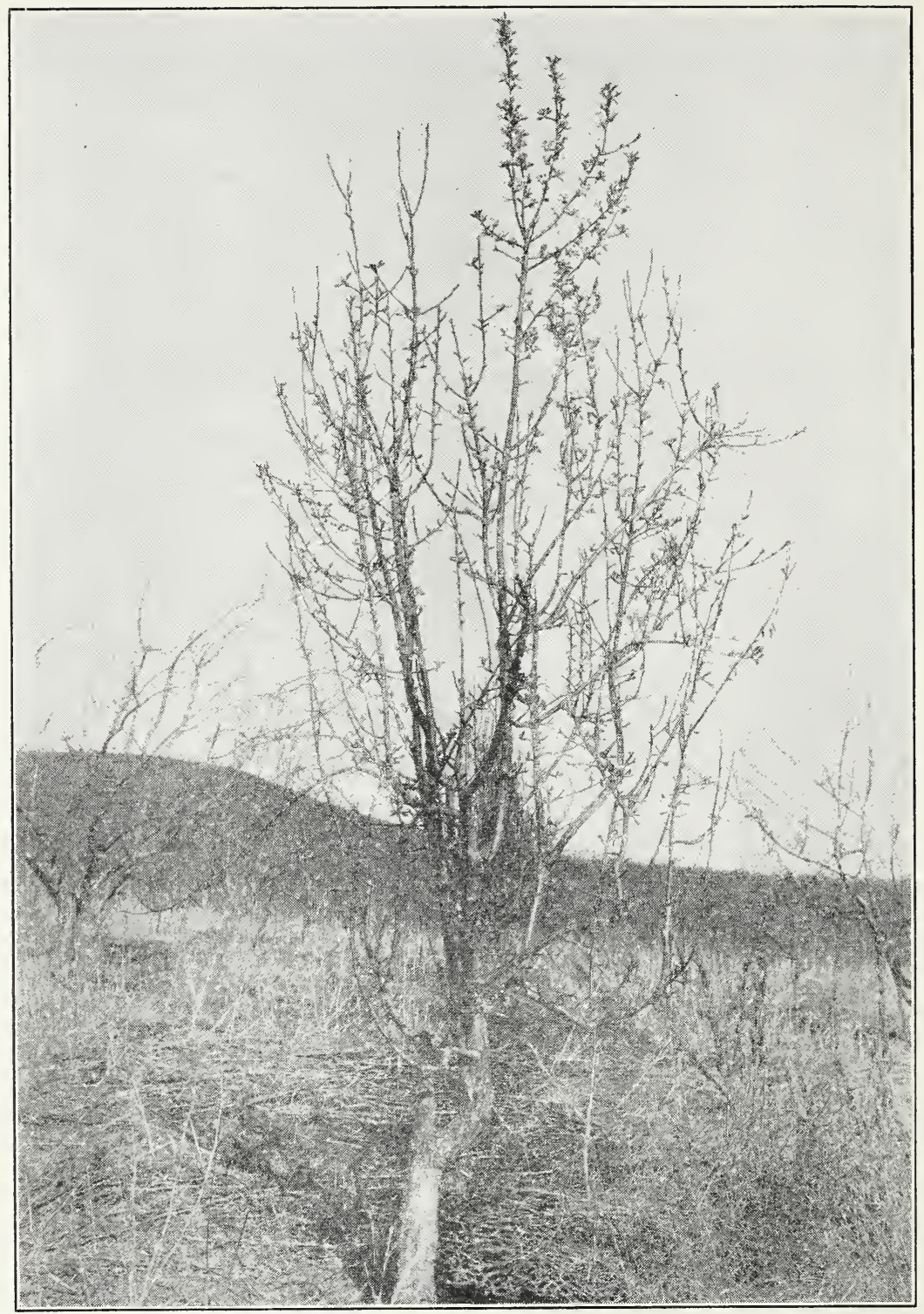

FIGURE 33.-Pear tree showing effects of severe attack by the tarnished plant bug. Only a few normal fruit buds are left in the top of the tree.

their escape in the spring. Spring cultivation, on the other hand, may drive the bugs into the trees. Control by means of sprays or with repellent or attractive materials has not been satisfactory. 


\section{Boxelder Bug}

Occasionally clusters of flat bugs, black with red lines and about one-half of an inch long, are found feeding on the maturing fruit (fig. 35). These are boxelder bugs (Leptocoris trivittatus (Say)), which occur chiefly in the vicinity of boxelder trees. They are sometimes mistaken for tarnished plant bugs, but may be distinguished by their larger size and conspicuous coloring. The adults hibernate in swarms in crevices about trees and buildings, and the young, which hatch from eggs laid in the spring, feed on the boxelder trees

Control consists mainly in prevention. Box-

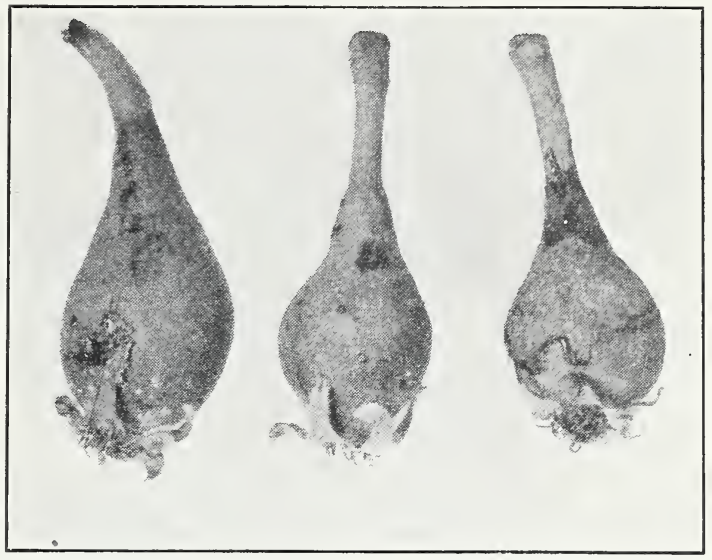

Figure 34.-Young pears injured by tarnished plant bug.

elder trees are of two kinds, those that bear seeds and those that do not, and only the latter should be planted, as the bugs live mostly

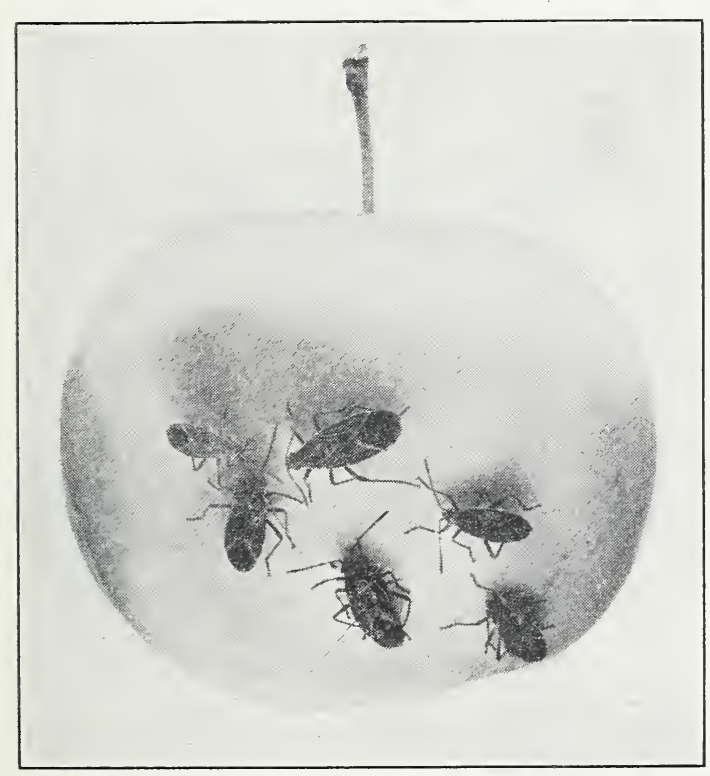

Figure 35.-Boxelder bugs feeding on apple. on the former kind. If seed-bearing trees occur in the vicinity of orchards, they should be replaced with other kinds of shade trees if possible. The hibernating adults may be destroyed with a spray of kerosene or strong oil emulsion.

\section{Climbing Cutworms}

In the spring, orchardists sometimes find that the opening buds on their trees are being eaten into and often entirely devoured, although no insects capable of causing the injury are visible. A careful search among the leaves or trash at the base of the tree will probably disclose the culprits. They are climbing cutworms, smooth, grayish-brown or blackish, greasy looking worms, usually curled up but ranging in length from $1 / 4$ to $1 \frac{1}{2}$ inches when stretched out. They lie quietly just beneath the 


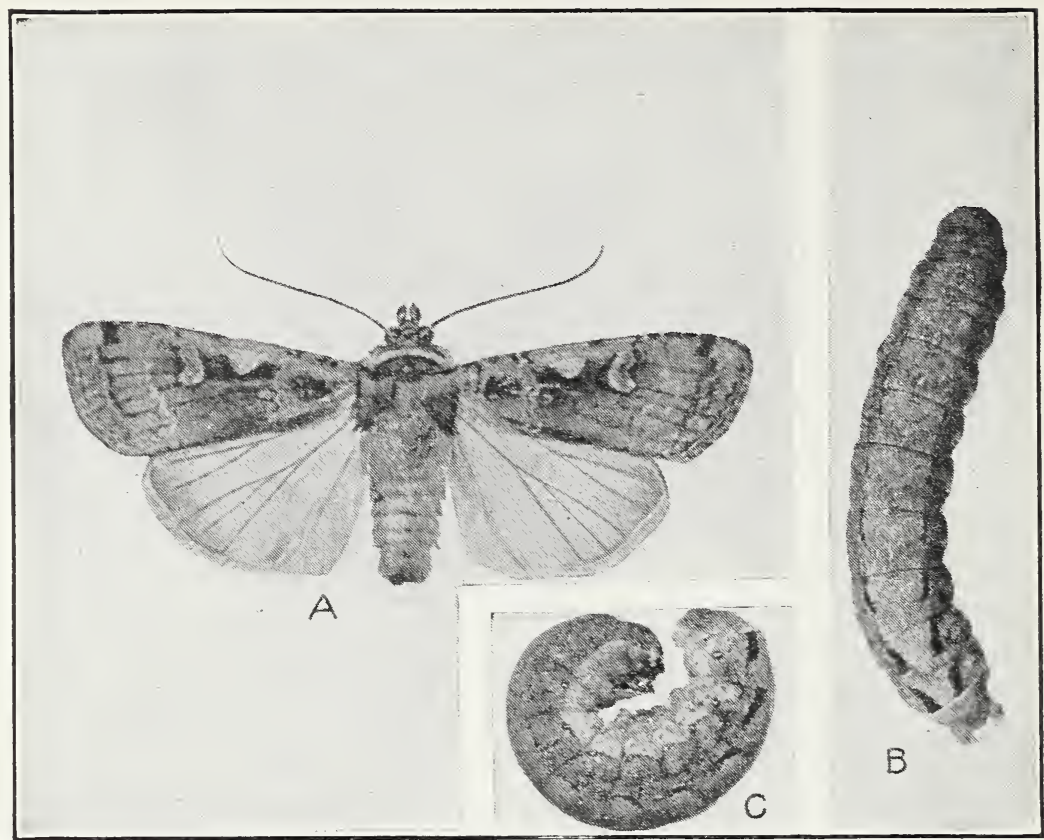

FigURE 36.-The spotted cutworm: A, Moth; B, larva extended; C, larva curled up. soil, under a leaf, or in a bunch of grass or alfalfa during the day, and climb into the trees at night to feed on the tender leaves and flower parts of the expanding buds. Frequently their presence is made known by many buds and portions of buds on the ground under the trees, dropped there by the worms as they feed. At times dozens and even hundreds of these worms may be found in the

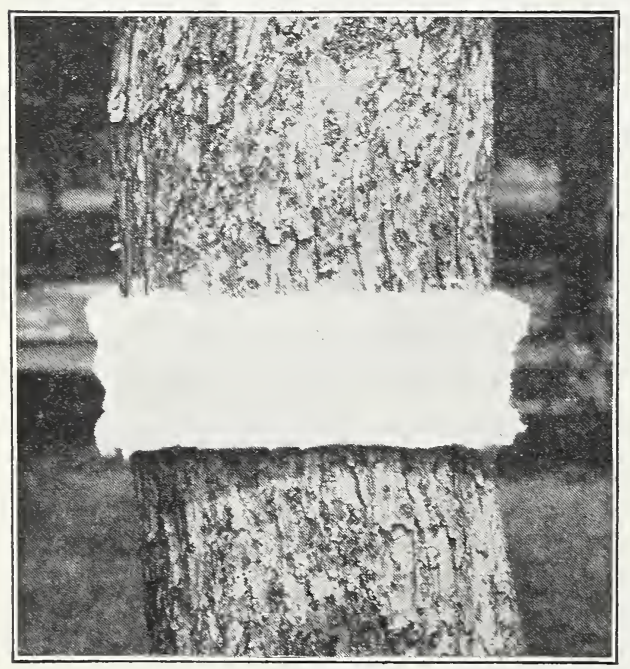

FIGURE 37.-Method of constructing cotton tree band. daytime under each tree, and such numbers cause severe damage.

In the Pacific Northwest several species of cutworms (Graphiphora c-nigrum (L.) (fig. 36), Abagrotis barnesii Benj., and Euxoa spp.) are responsible for most of the damage of this type done to fruit trees. Their habits are similar. Most of them spend the winter as small, partly grown worms, coming out of hibernation in the spring voraciously hungry. For a time the tender buds of fruit trees offer a very attractive food supply, and most of the damage is caused over a relatively short period. Later the worms feed on alfalfa 
and other ground plants. When full-grown they construct cells in the soil, where they pupate, and the orange-brown pupae are often turned up when the soil is plowed or spaded. The moths emerge at various times during the summer and are among the fairly large, dull grayish or brownish moths seen flying about lights at night. There may be one or more generations, but later generations are of little consequence, as vegetation is plentiful by the time they appear. Eggs are deposited in the fall on the trees or cover crops in patches of a hundred or more. After the eggs have hatched the small worms feed for a time before going into hibernation.

\section{CONTROL}

The most effective means of control consists of placing bands of suitable material on the tree trunks to prevent the

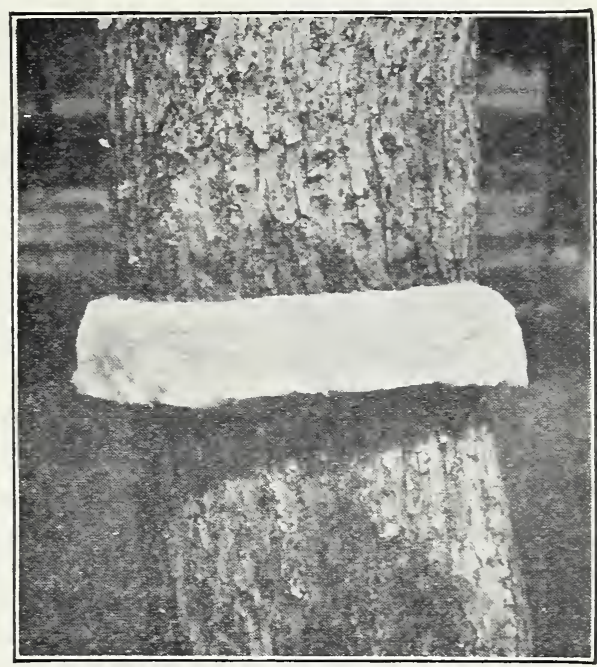

Figure 38.-Completed cotton tree band. worms from climbing into the trees. Sheets of cotton batting cut into strips 5 or 6 inches wide may be used. A strip should be wrapped around the trunk, overlapped an inch or so, and tied tightly with

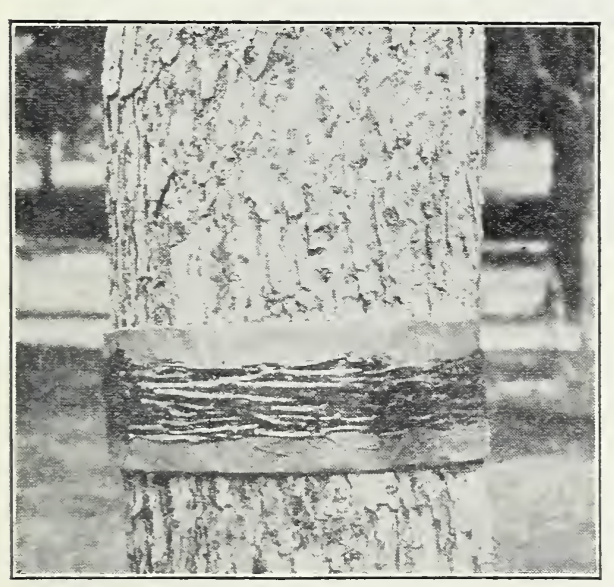

FIGURE 39.-Band of paper and sticky material. twine near the bottom of the band (fig. 37); the top of the band should then be pulled or rolled down over the twine (fig. 38), forming a sort of inverted funnel in which the worms are caught. On rough or uneren trunks it may be necessary to fill in depressions under the bands with extra cotton or to put a thin band of some sticky substance on the tree before the cotton band is applied, to prevent the worms from crawling under it.

Bands of sticky material (fig. 39) or of axle grease are often used. They should be 3 or 4 inches wide, and are effective only as long as they remain sticky. Dust blown by the wind or from cultivating operations often covers these bands and makes them useless. They should not be put on young or smoothbarked trees, as they roughen and may kill the bark.

Baits are very generally used to control cutworms in gardens and fields, and are of some value against climbing cutworms, especially in 
moist climates. They are less valuable in arid regions, where they dry out too rapidly. A suitable bait may be made of the following materials:

Wheat bran or shorts
Paris green or powdered white arsenic or 25 pounds.
sodium fluoride, or sodium fluosilicate_... 1 pound.
Water._.

A small handful of the bait placed at the base of each tree is sufficient. The bait is attractive only while it is moist, and a light covering of grass or hay will keep it in this condition longer. Half of the water used may be replaced by glycerin to prevent rapid drying of the bait. Young children, livestock, poultry, or birds should not be allowed to get at the bait, as it is very poisonous. Vessels used for mixing it should be cleaned thoroughly before the bait dries, as they are difficult to clean afterwards.

\section{Green Fruitworms}

Related to the cutworms are the green fruitworms (Graptolitha spp.). When young these worms feed on buds and leaves and are not often noticed, but when about half-grown they begin feeding on

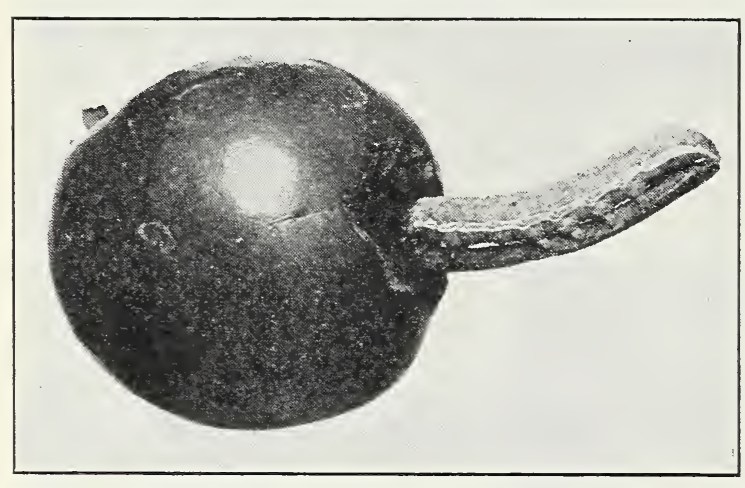

FIGURE 40 . - Green fruitworm feeding on apple. $\times 2$. the fruit (fig. 40). They are then smooth green worms, an inch or so long, which eat large holes in the developing apples or pears. They are most often seen during May and June. The fruit that is attacked may drop off, or if the cavities are shallow they heal over and result in russeted scars. When the worms are fullgrown they make cells

in the ground, where they transform to brown pupae in a manner similar to that of the cutworms. The moths emerge late in the fall or early in the spring and lay eggs singly on the trees. Control measures are not often needed, as the sprays applied for the codling moth usually prevent the fruitworms from becoming very injurious. Most of the damage is done early, and affected fruits may often be thinned off without much loss. If special control is necessary, lead arsenate, 3 pounds to 100 gallons, should be used alone or added to a scab spray when the blossoms are in the pink.

\section{Eye-Spotted Budmoth}

The eye-spotted budmoth (Spilonota ocellana (D. and S.)) occurs in Idaho, northeastern Washington, and the region west of the Cascade Mountains. The injury to the fruit, which is caused by the young, 
consists of irregular surface feeding or a series of small holes in the skin (fig. 41). Sprays used for controlling the codling moth on apple and pear usually prevent this insect from becoming a serious pest on these fruits (p. 5). If additional control is necessary, lead arsenate, 3 pounds to 100 gallons, may be added to the pink spray of lime-sulfur solution which is often used for scab or mildew, or the lead arsenate may be used alone at this time.

\section{Flatheaded Borers}

Two species of flatheaded borers, the flatheaded apple tree borer (Chrysobothris femorata (Oliv.)) and the Pacific flatheaded borer (C. mali Horn), occur in the orchards of the Pacific Northwest. They are very similar, the adult beetles (fig. 42) being flattened, and dark greenish blue or dark bronze with coppery spots. The larvae or borers are most often

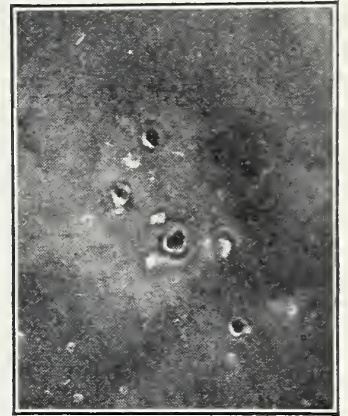

Figure 41.--Holes in an apple made by larvae of the eye-spotted budmoth. injurious to young trees, particularly those weakened from sunburn or other causes. They are waxy white, about an inch long when fullgrown, legless, and with the fore part of the body broad and flat (fig. 43). The beetles emerge in the spring and lay eggs on the tree trunks,

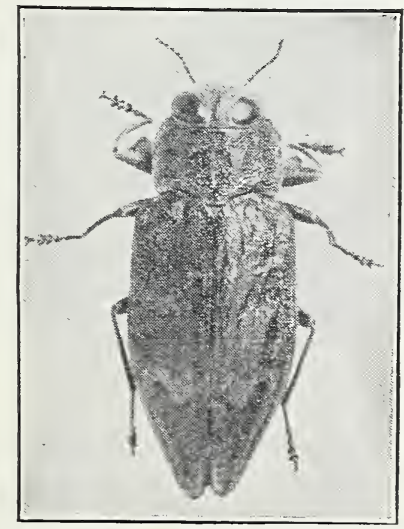

Figure 42.-Flatheaded apple tree borer (adult). $\times 3$.

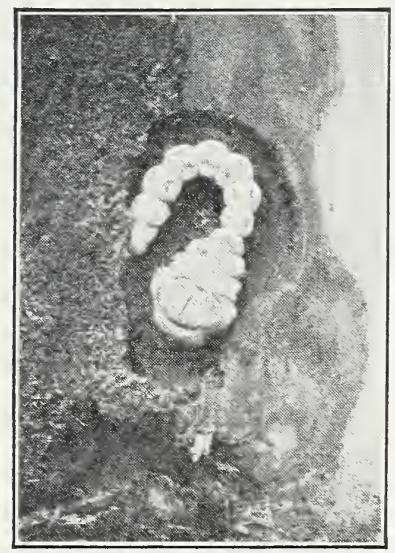

Figure 43.-Flatheaded apple tree borer. Slightly enlarged.

preferably in the sun. The young borers burrow into the bark and require a year or more for complete development. Both species are native American insects.

Trees should be kept in a resistant, healthy condition, as the young borers are unable to thrive in vigorous trees with strong-flowing sap. If the trunks of young trees are protected with whitewash, or if a board or stave is placed so that it will shade the trunk, danger of injury will be reduced. 


\section{Pear Blight Beetle}

In the coastal area small, round holes, looking like shot holes, are sometimes found in the trunks of apple and pear trees (the work of a related species, the shot-hole borer (Scolytus rugulosus Ratz.) is shown in fig. 44). These are made by a small, blackish beetle, the pear blight beetle, also known as the larger shot-hole borer (Anisandrus pyri Peck). Trees are not attacked unless they are in an unhealthy condition, which may have been brought about by mechanical or winter injury, too much water, drought, insects, fungous diseases, or some other cause. Any condition that may result in souring of the sap

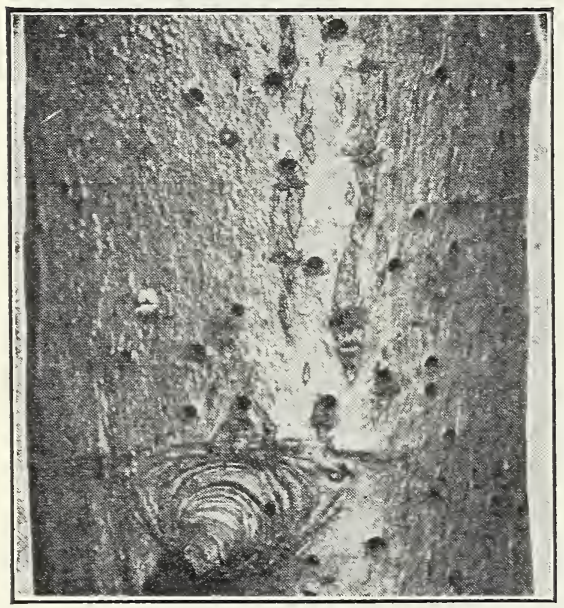

FIGURE 44.-Work of the shot-hole borer, Scolytus rugulosus. will attract the borers. The beetles bore into the sapwood and make tunnels through it in which they lay eggs. The souring sap favors the growth of a fungus, and the young grubs feed on this fungus and not at all on the wood. In the fall the grubs transform to beetles, which remain in the tunnels until spring, when they emerge and construct fresh tunnels. If the tunnels are numerous, the growth of the trees may be affected seriously.

In order to prevent attacks of this beetle, the trees should be kept in a healthy, vigorous condition; and if they are unhealthy, the cause should be determined and corrected if possible. A wash for slightly infested trees or limbs, consisting of $1 / 2$ pint of crude carbolic acid, 1 gallon of fish-oil soap or other soap, and 3 gallons of water, has been recommended by the Oregon Agricultural Experiment Station. This should be painted carefully on the infested portions only.

\section{Bronze Apple Tree Weevil}

The bronze apple tree weevil (Magdalis aenescens Lec.) attacks devitalized apple and prune trees, making several small holes in a patch in the bark. These are egg punctures, and the grubs hatching from the eggs feed beneath the bark, causing a sunken, discolored area about the size of a silver dollar. The adult beetles, which are small, bronzy or black, and have snouts, emerge the following spring. Attacks of this weevil may be prevented and controlled in the manner described for the pear blight beetle.

\section{Flower Thrips}

Irregular whitish patches with dark centers very frequently appear on the skin of apples (fig. 45). These have been called "pansy spots," because they often resemble pansies in shape. They are most noticeable on immature apples, and there may be 25 or 30 of them on 
a single fruit. They usually disappear as the fruit ripens, but persist on certain varieties, such as the McIntosh, Northern Spy, and Yellow Newtown. Badly spotted apples must often be put in a lower grade. The spots are the result of egg punctures made by the flower thrips (Frankliniella tritici (Fitch)) and probably other species. The thrips normally live in dandelions and other flowers, but are attracted to the apple blossoms and lay many of their eggs in the newly formed fruits. The thrips larvae emerge from these egg punctures, leaving small holes in the skin of the apples. These holes become the central spots

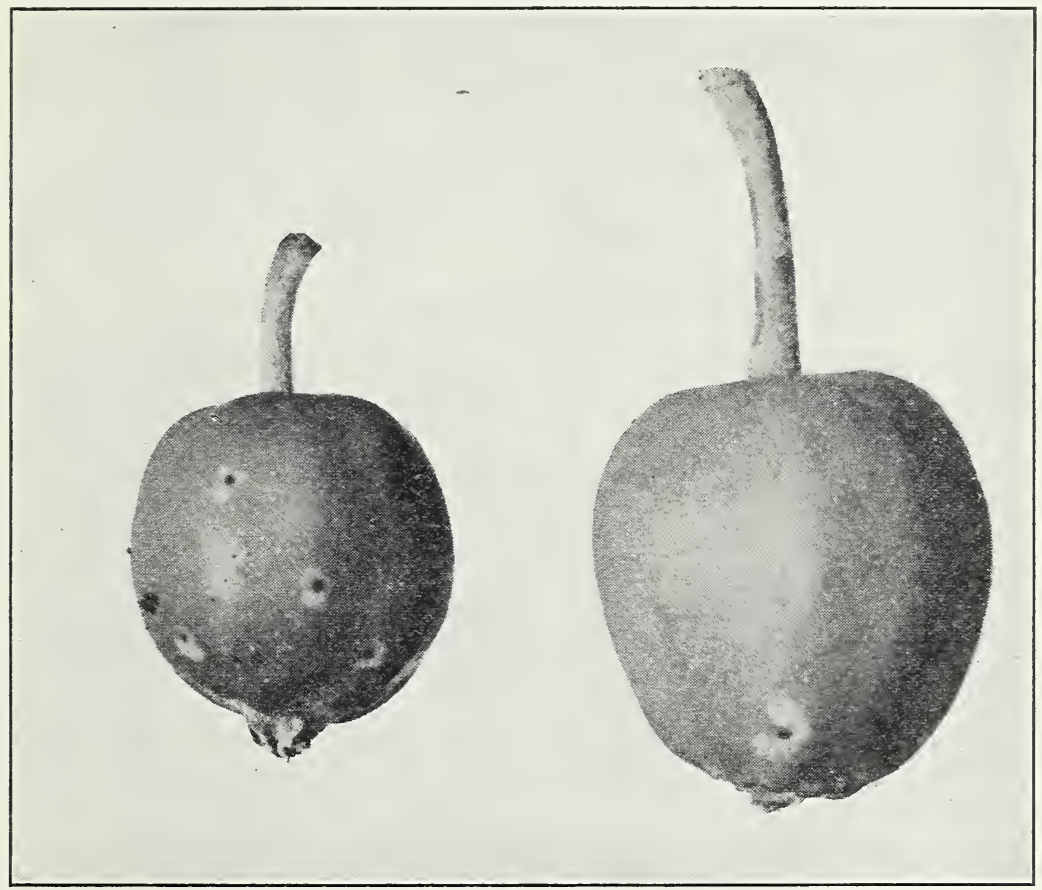

FigURE 45.-So-called "pansy spots" caused by the flower thrips.

of the "pansies." The irregular whitish areas that form about these centers as the fruit grows result from the presence of the eggs in the apples. Nicotine sulfate (40 percent nicotine), in the proportion of 1 pint to 100 gallons of water, to which is added several pounds of soap in solution or a pound of casein spreader, will effect some degree of control if used when the trees are in full bloom; or the nicotine may be added to the calyx spray.

\section{Pear Thrips}

The pear thrips (Taeniothrips inconsequens (Uzel)) occurs on pears, but in the Pacific Northwest it is more serious as a prune pest, and it is therefore discussed under that heading (p.56). The recommendations given there also apply to pear trees, except that where it is necessary to control scab, oil should not be used, but nicotine sulfate 
(40 percent nicotine) should be added to the delayed-dormant and pink-petal applications of lime-sulfur at the rate of 1 pint to 100 gallons of spray material.

\section{Apple Leafhoppers}

The leafhoppers injure apple trees in much the same manner as do red spiders. They are sucking insects feeding exclusively on the foliage, and they withdraw the chlorophyll and other cell contents, leaving the foliage with a whitened or mottled appearance. Leafhoppers are much larger than red spiders, and it does not require many of them to cause serious injury; a half dozen are able to remove most of the chlorophyll from a single leaf. Slight foliage injury by leafhoppers and red spiders is of no consequence, but as soon as this injury reaches the point where the foliage is reduced below the amount required for the crop, the fruit and buds are directly affected, the fruit failing to reach normal size and the buds being weakened so that they may not set fruit the next season. It is therefore important to guard against extensive injury.

\section{LIFE HISTORY}

Two species of leafhoppers are prevalent in the Pacific Northwest, both native to the United States. The more common and important of these is the white apple leafhopper (Typhlocyba pomaria McAtee), a slender, active, whitish insect about one-eighth of an inch long. It passes the winter in the egg stage in the bark of the trees. The eggs hatch in April and early in May, and the small white hoppers commence to feed at once on the new foliage, remaining among the pubescence of the underside of the leaves. Growth is attained in 3 to 6 weeks, and the adults live for 2 months or more. Eggs are laid in the tissue of the leaves from June to August, and hatch in about a month. The second brood of young thus appears late in July and August, and adults are present again from August to November. These lay wintering eggs in the bark, where they appear as small raised blisters.

The apple leafhopper or green apple leafhopper (Empoasca maligna (Walsh)) has only one generation a year, beginning with the wintering eggs, which are usually laid in the bark of wood 2 or 3 years old. The eggs hatch in April or May; and the young, which are light green instead of white, feed in the same manner as do the white apple leafhoppers. The green adults appear in May and June and some are still present in July. Most of the eggs are deposited in June and July, and these remain in the bark until the following April. Since it has only a single generation annually, this leafhopper does not become so numerous as the white species.

\section{CONTROL}

The most effective means of controlling leafhoppers is the use of a spray of nicotine sulfate (40 percent nicotine) in the proportion of one-half pint to 100 gallons, used with an oil emulsion, or with 2 or 3 pounds of soap dissolved in water, or with 1 pound of casein spreader. This must be used when the young are on the trees, as the adults are too active to be reached with a contact spray. The application should therefore be made in May for the green leafhopper or the first 
generation of the white leafhopper, and in late July or August for the second generation of the latter. The nicotine spray may often be combined with an oil emulsion and used in place of one of the applications of lead arsenate for the codling moth. The lime-sulfur spray, which is used in May in some districts for apple scab or powdery mildew (table 1, p. 71), constitutes an excellent control for leafhoppers, and when it is used nicotine sulfate should not be needed.

\section{Syneta Leaf Beetle}

The syneta leaf beetle (S'yneta albida Lec.) seldom injures apples, but may cause a reduction of 50 percent or more in the pear crop.

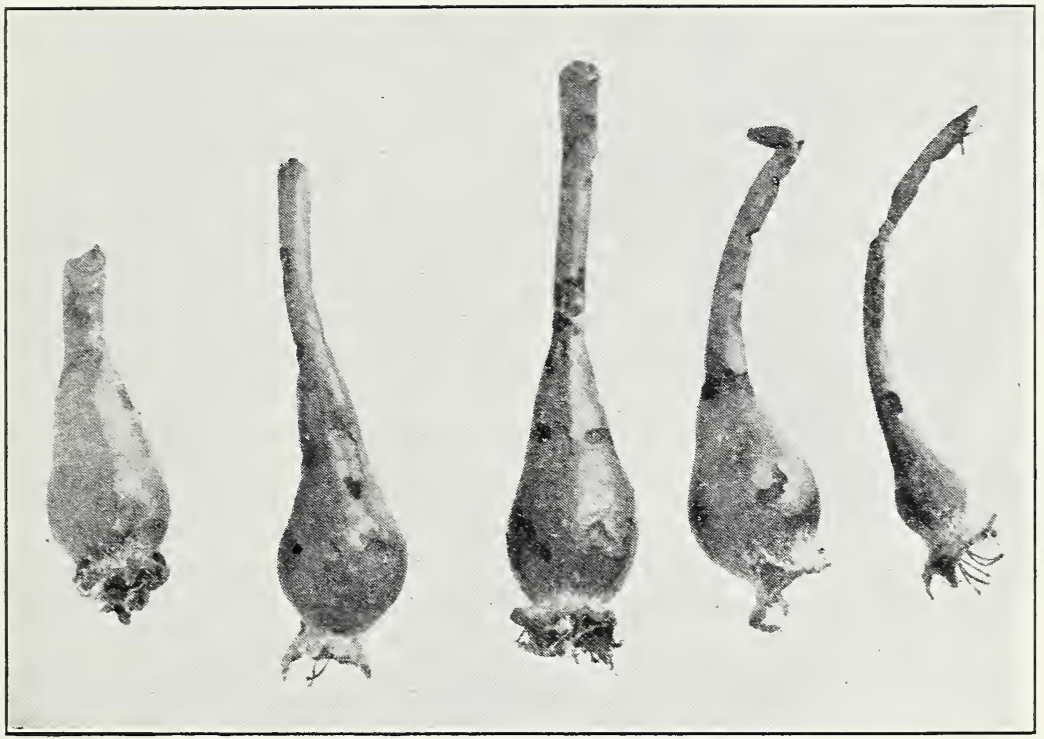

FigURe 46.--Young pears injured by the syneta leaf beetle.

The injury consists of scars and deformities on the fruit, caused by the beetles when feeding. The beetle also chews the fruit stems (fig. 46), and causes some of the fruit to drop. Practically all of the injury is done during April and May. The life history of the beetle is discussed on page 49 .

\section{CONTROL}

Good control of the beetles on apples and pears may often be obtained by a single thorough application of lead arsenate at the rate of 3 pounds to 100 gallons of water used as a calyx spray. If the infestation is severe a second application may be made 10 days or 2 weeks later.

\section{Western Tent Caterpillar}

The western tent caterpillar (Malacosoma pluvialis (Dyar))is practically limited in its depredations to the region west of the Cascade Mountains. The caterpillars appear in May and June, constructing 
tents of webbing in the crotches or about the smaller twigs and leaves of the trees. (The tents are similar to those of the eastern tent caterpillar shown in figure 47.) The caterpillars feed roraciously during the day, devouring all of the leaf tissue except the midribs, and retire at night to the tents, or collect in masses on the larger limbs. These caterpillars occur sporadically and in some years are numerous enough to defoliate not only fruit trees but wild growth and shade trees as well.

\section{LIFE HISTORY}

The insect passes the winter in the egg stage. The eggs are laid in masses surrounding the twigs, each mass containing several hundred

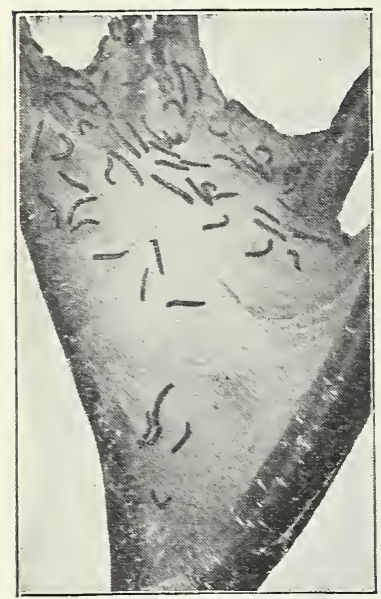

FIgURE 47.--Larvae and nest of the eastern tent caterpillar (Malacosoma americana F.). eggs covered with a frothy, waterproof material. The young caterpillars appear about the time the apple buds begin to open. The group hatching from a single egg mass constructs a small silken nest or tent, and as the caterpillars grow this nest is enlarged to provide adequate protection for the colony. The caterpillars are somewhat hairy, tawny brown, with a row of blue spots flanked by orange spots along the back. When full-grown they are nearly 2 inches long. As the caterpillar's become larger they tend to scatter, and their cocoons may be spun in various sheltered places, such as under loose bark, in curled leares, or under projecting eares of nearby buildings. The cocoons are tightly woren of yellow silk, surrounded with a loose mass of silk. The moths emerge in June or July and soon deposit the overwintering egg masses.

\section{CONTROL}

Many of the egg masses may be found and destroyed when the trees are pruned. If the small caterpillars are numerous, a spray of lead arsenate, 2 pounds to 100 gallons, applied just before the trees bloom, is very effective. If the spraying is done later, the quantity of lead arsenate should be doubled, as the larger caterpillars are more resistant to the poison. Very often the tents can be pruned out and destroyed or burned out with a torch, moving the flame rapidly so as not to injure the tree. The tents should be destroyed at night when most of the caterpillars are congregated in them.

\section{Fall Webworm}

Although the habits of the fall webworm (Hyphantria cunea (Drury)) are somewhat similar to those of the tent caterpillar, there is enough difference to remore any difficulty in distinguishing the two insects. As the name implies, the fall webworm appears late in the summer and constructs a loose and very unsightly nest of webbing about a number of twigs (fig. 48). These nests are extended as the caterpillars grow and often enclose entire branches. The caterpillars feed within the webs, devouring the leares and fruit. When full-grown the caterpillar is about $1 \frac{1}{4}$ inches long, covered with long, whitish hairs, and 
with a dark band along the back. It constructs a flimsy, brown cocoon in trash on the ground; from this cocoon the moth emerges late in the spring. The moth is usually pure white or spotted with dark-colored dots. It lays pale-green eggs in a flat mass on a leaf, covering them with white hairs from its body. The egg's hatch in about 10 days. There is only one brood annually in the Pacific Northwest. The insect occurs in the area west of the Cascade Mountains and in Idaho.

Apple and pear trees that are regularly sprayed with arsenicals are not harmed by the fall webworm, as the caterpillars appear after some of these sprays have been applied, and the small worms succumb readily to the poison on the foliage. On shade trees or fruit trees not ordinarily sprayed, a special application of lead arsenate, 2 pounds to 100 gallons, is effective if applied while the cater-

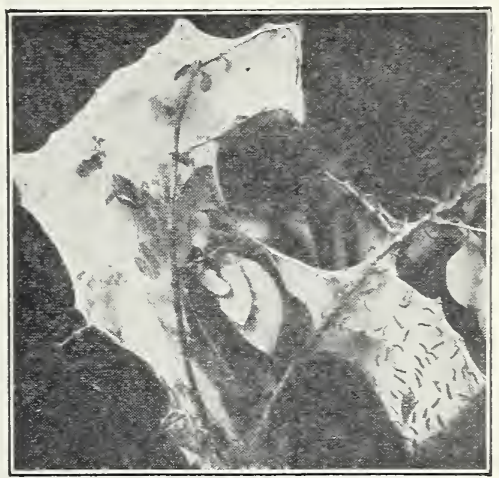

Figure 48.--Nest of the fall webworm. pillars are still small. The caterpillars may also be destroyed in their webs by burning, as suggested for the tent caterpillar. This may be done during the day.

\section{Tussock Moths}

The rusty tussock moth (Notolophus antiqua (L.)) and the western tussock moth (Hemerocampa vetusta (Bdv.)) are leaf-feeding insects occurring chiefly west of the Cascade Mountains. The first-mentioned species passes the winter in the egg stage in dry leaves or on tree trunks or twigs. The caterpillars appear in April and subsist mainly on the foliage, but occasionally damage the fruit, and may be found on a great variety of trees and shrubs. They feed for a month or more, and when full grown are about 1 inch long, hairy, blackish or bluish, with several thick tufts of hairs along the back. The male moth has rusty-brown wings, but the female is practically wingless and deposits her eggs in a mass on the cocoon from which she emerged. A second brood of caterpillars appears late in July and produces moths in September; these in turn deposit the overwintering eggs. The western tussock moth has similar habits, except that there is but a single brood each year, the eggs laid in July hatching the following spring. Special control is seldom necessary, since sprays applied for other leaf-feeding caterpillars keep these insects in check. Many of the egg masses may be found and destroyed when the trees are pruned.

\section{Apple Lacebug}

The apple lacebug (Corythucha drakei Gibs.) is a pest of the apple in Washington and Oregon. The young and adults feed on the lower surface of the leaves, usually in groups. They dot the leaves with black spots of excrement, and as the insects suck out the juices the leaves become yellowed and erentually drop. The adult insect is 
about one-eighth of an inch long, grayish, flattened, with lacelike wings. Eggs are deposited on the leaves, and there are probably two or more generations annually. Fair control may be effected by using three-fourths of a pint of nicotine sulfate (40 percent nicotine) to 100 gallons of water, to which is added some soap or spreader. The underside of the leaves must be thoroughly sprayed.

\section{Apple Leaf Miner}

In western Oregon and in the Hood River Valley the apple leaf miner (Phyllonorycter crataegella Clemens) may be found in apple

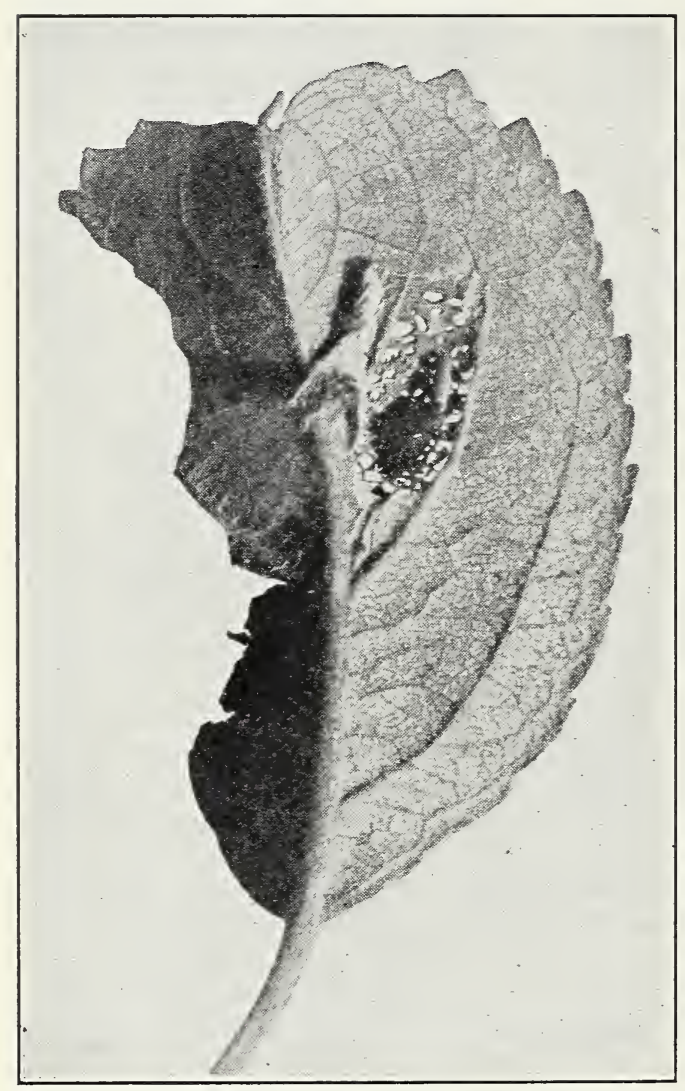

FIGURE 49.-Work of apple leaf miner in apple leaf. leaves and also in leares of the wild hawthorn. It constructs blotchlike mines in the leaf (fig. 49) between the large veins and causes the leaf to become somewhat misshapen. The adult insect is a very small, silvery moth which lays eggs on the leaves. The young worm burrows between the upper and lower leaf surfaces, forming the mine. When full grown it pupates within the mine, and the moth emerges soon after. There are probably two broods in a season. In the fall the worms make silken bibernacula in the mines, where they spend the winter in the fallen leaves. This pest is of minor importance. Any cleaning up or cultivation that destroys or buries the leaves late in the fall would prevent many of the moths from emerging the following spring.

\section{Apple Fruit Miner}

The serpentine or apple fruit miner (Marmara pomonella Busck) is more of a curiosity than a pest. The adult is a very small moth, the young of which form winding whitish mines just under the skin of the apple (fig. 50). The mines are also occasionally found on prunes. This insect occurs so rarely that control measures are not necessary. 


\section{Pear Slug}

The pear slug (Caliroa cerasi (L.)) feeds on the foliage of pear and cherry trees, skeletonizing the leaves by eating the upper surfaces (fig. 51). The larvae are slimy and sluglike in appearance, olive green or almost black, and about one-half of an inch long when full-grown. When they are numerous the whole tree becomes brown, as though swept by fire. This should not be allowed to happen to valuable trees, as the reduction in the leaf surface seriously interferes with the growth of the fruit and with the development of fruit buds. This insect is widely distributed in the United States, having come in from Europe.

\section{LIFE HISTORY}

The adult insects are glossy black, four - winged flies,

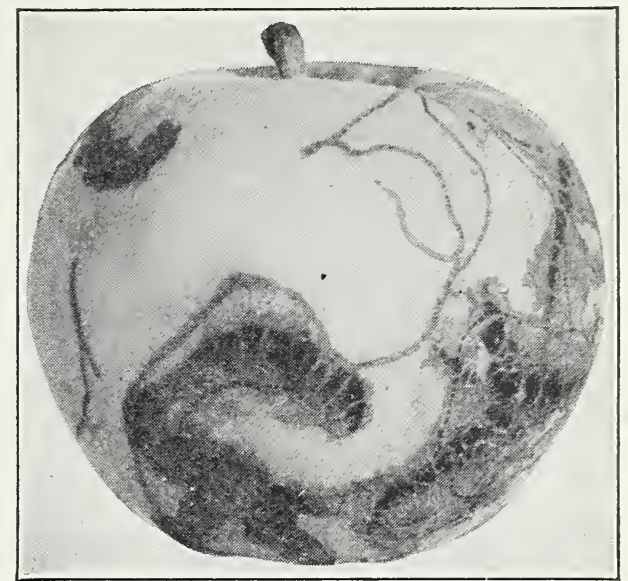

FIGURE 50.-- Work of the apple fruit miner. about one-fifth of an inch long. They are known as sawflies because they cut slits in the upper surface of the leaves, in which the eggs are laid. The eggs in the leaves have the appearance of small blisters.

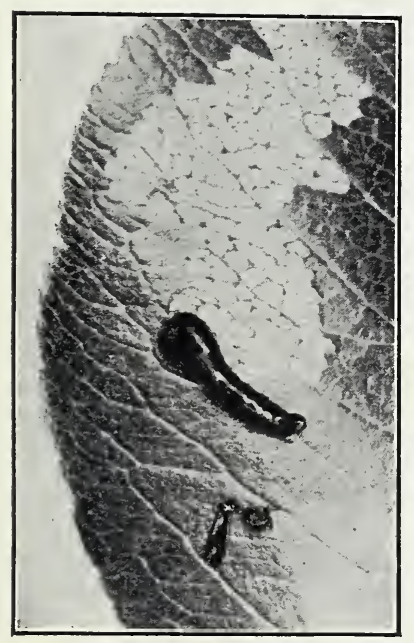

Figure 51.--Pear slug and its injury. About $\times 2$.

The young slugs hatch in a week or two and feed almost altogether on the upper surface, usually avoiding any leaves that may have been attacked by aphids or blister mites. Just after molting the slugs are yellow, but they soon secrete a slime which gives them the characteristic olive green or black color. Their bodies are somewhat enlarged in front and taper behind. The slugs complete their growth in less than a month, drop to the ground, and form cells in the soil, within which they transform to adults in a couple of weeks. The second brood of slugs appears on the trees in August, and these, when full-grown, spend the winter in earthen cells from which the adult sawflies emerge the following spring.

\section{CONTROL}

The pear slug is very easily controlled and does not become a pest if any arsenicals are used on pear trees in the spring for other insects. If the slug is the only insect present, an application of lead arsenate in the proportion of 2 pounds to 100 gallons of water is very effective, or lead arsenate or hydrated lime may be used as a dust. If it is necessary 
to spray for the second brood in August, spraying should be delayed until after the crop has been harvested, or nicotine sulfate (40 percent nicotine) in the proportion of $3 / 4$ of a pint to 100 gallons of water, to which is added 2 or 3 pounds of soap in solution, should be used in order to avoid getting too much lead arsenate on the fruit just before it is harvested.

\section{Pear Leaf Worm}

Round or oval holes, half an inch or more in diameter, are sometimes found in pear leaves late in April or in May. A close examina-

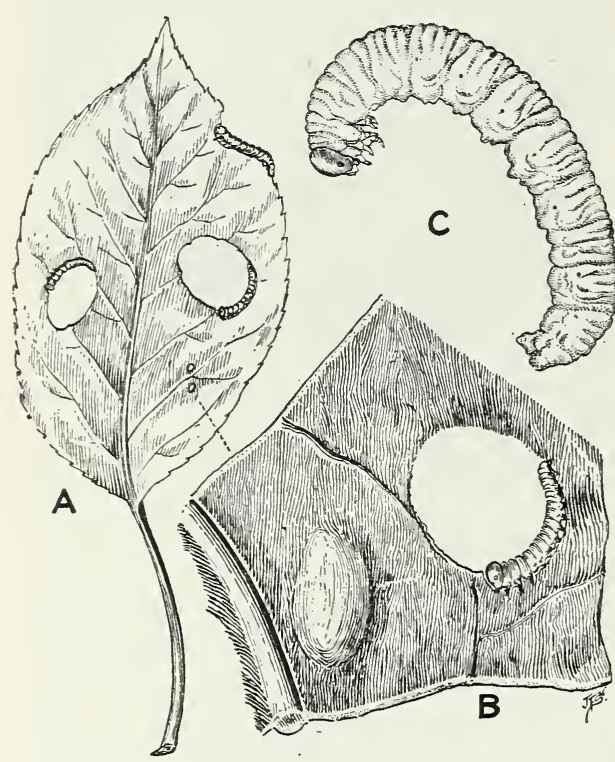

Figure 52.--Pear leaf worm: A, Injury to leaf; $B$, egg in tissue and young larva feeding ( $X 12)$; C, full-grown larva $(X, 6)$. tion will usually show a green worm stretched along the edge of each hole, feeding on the leaf (fig. 52). This is a pear leaf worm (Gymnonychus californicus Marlatt). 'The young' worms first make small holes in the leoves, gradually enlarging the holes as they feed around and around them. A single worm will consume about onefourth of a Bartlett pear leaf during its life, and when the worms are numerous the trees may be partially defoliated. This insect occurs throughout the Pacific Northwest and in California.

\section{LIFE HISTORY}

The adult insects are sawflies similar in appearance to those of the pear slug, but somewhat more slender and with some yellowish markings. They emerge from the ground early in April and cut slits in the lower surfaces of the partly unfolded leaves, in which the eggs are laid. The wounds often cause the leaves to become deformed. The small green worms hatch in 10 days or 2 weeks and feed as described above. Growth is attained in about 4 weeks, when the mature worms, which are about one-half of an inch long, drop to the ground and spin tough brown cocoons among the leaves or in the soil within an inch or so of the surface. Here they remain until the following April, as there is only one generation a year.

\section{CONTROL}

The pear leaf worm is very easily controlled by the use of lead arsenate in the proportion of 2 pounds to 100 gallons of water, applied just after the petals have fallen. This is the same as the usual calyx application for the codling moth. 


\section{Dock SAwfLY}

Apples are occasionally found in the fall with round holes in them resembling those made by full-grown codling moth larvae. If the fruit is cut open, a bright-green worm may be found inside (fig. 53). This is the larva of the dock sawfly (Ametastegia glabrata (Fall.)), an insect that has come in from Europe. The adult sawfly lays eggs in the leaves of dock, wild buckwheat, sheep sorrel, and related plants which often grow along ditch banks and in moist places in orchards. The young feed altogether on these plants (fig. 54), and when fullgrown they search for suitable places in which to transform to adults. Usually they burrow into the dry, hollow, or pithy stems of alfalfa or mustard, or into the stems of their food plants. But if apples are near by, and particularly if they are hanging low in the cover crop, the worms may construct cells in the apples instead of in the plant stems. The injury caused by this insect is ordinarily negligible. If it should occasionally become serious, it can be reduced by keeping the orchard free of dock and related plants or by propping up lowhanging branches, and

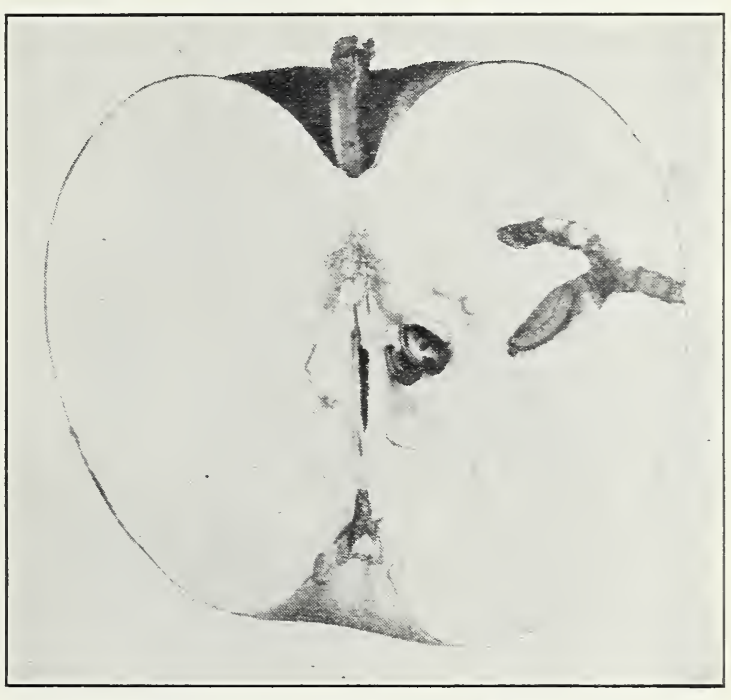

FIgURE 53.-Larva of dock sawfly in apple. by banding the props and the tree trunks with cotton or some sticky substance in August and leaving the bands on until after the fruit has been harrested.

\section{Ants}

Orchards of the Pacific Northwest are sometimes troubled by ants, particularly the large pugnacious red ants (Formica spp.) that build nests in the ground, often covered with rather conspicuous heaps of dried stems and twigs of plants. These ants are attracted to the trees primarily to feed on the honeydew excreted by aphids. At times the ants may chew the blossoms and cause direct injury in that manner. If the nests are not adjacent to the trees or other valuable plants, the ants may be eradicated or greatly reduced in numbers by placing about an ounce of granular calcium cyanide in the center of the hill or nest, sereral inches below the surface, and covering it with dirt. This material is dangerous to use near growing plants, and in such cases some control may be obtained by drenching the nests with water containing a pyrethrum extract. This should be used at the strongest 
dilution recommended by the manufacturer (usually about 1 gallon to 200 gallons of water).

\section{CHERRY INSECTS}

\section{San Jose Scale}

The San Jose scale is not often very injurious to sour cherries, but it does a great deal of damage to sweet cherries. As these trees usually

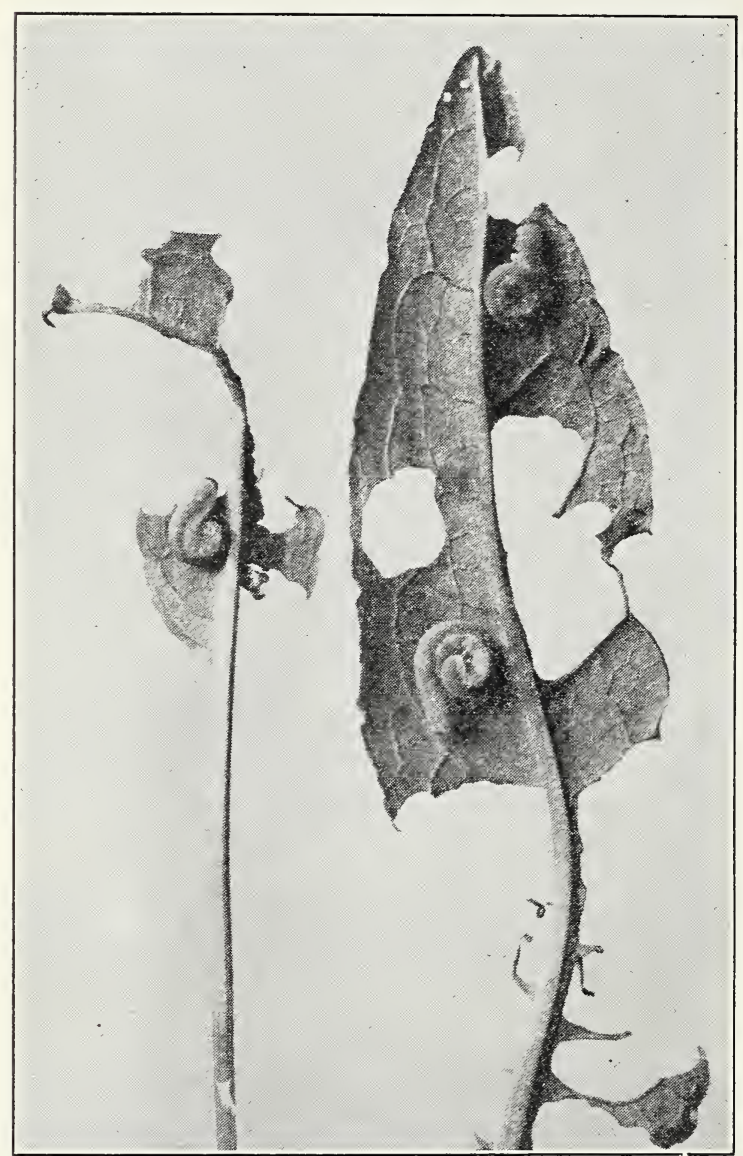

Figure 54.- Larvae of dock sawfly feeding on dock leaves. $\times 4$ grow large, the tops are difficult to spray thoroughly, and it is a common thing to see dead leaves clinging to the upper branches of large sweet cherry trees during the winter. This is an almost sure indication that these branches are infested with the scale. Treatment is the same as for scale on apple and pear trees (p. 11). The tops may often be reached by climbing into the trees and spraying the tops first.

\section{Black Cherry ApHID}

The black cherry aphid (Myzus cerasi (F.)) is a large, shiny, black aphid which occurs on the young foliage of cherry trees and often interferes with the terminal growth. It is much more often found on sweet cherry trees than on the sour varieties, and is particularly injurious to young trees and to nursery stock. The leaves of infested trees are severely curled (fig. 55) and covered with a sticky honeydew. This aphid is a European species that has become prevalent in the United States.

\section{LIFE HISTORY}

The winter eggs, which are tucked in among the buds, hatch about the time the buds burst, and the young develop rapidly on the new growth, curling the leaves and feeding within the protection thus 
afforded. There are several generations. Winged adults develop in the middle of the summer and migrate to water cress, peppergrass, and other plants of the mustard family. A later generation returns to the cherry in the fall and produces wingless individuals that lay the overwintering eggs.

\section{CONTROL}

Spraying after the leaves are curled is of little use, but very good control may be obtained by spraying just as the buds are breaking. Nicotine sulfate (40 percent nicotine) may be used in the proportion of three-fourths of a pint to 100 gallons of water, with soap or casein spreader, or added to dormant sprays of limesulfur or oil.

\section{RED SPIDERS}

On cherry trees the webspinning mites (Tetranychus pacificus McG. and T. willamettei McG.) are usually more injurious than other species of red spiders. They hibernate beneath the fallen leaves or in other trash and migrate into the trees in the

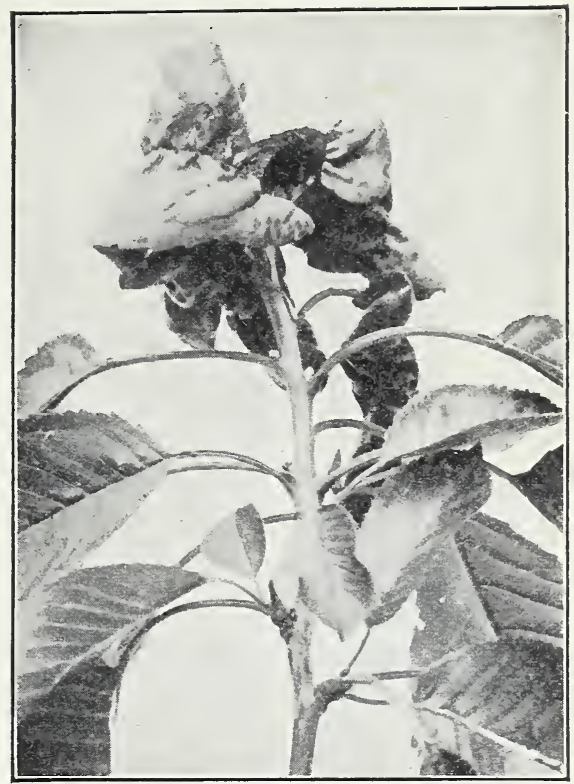

FiguRE 55.--Injury to cherry foliage by the black cherry aphid.

spring as soon as the new leaves have appeared. They are not often seen before June and do their most serious injury after the fruit has been picked. Cherry trees are frequently neglected at this time and allowed to become dry; this condition aggravates the injury caused by the mites and may very materially reduce the succeeding year's crop by weakening the fruit buds. If cherry trees have a dry and dusty appearance late in the summer, it may be suspected that mites are on the trees. Closer examination will reveal the webbing, in which the small greenish or yellowish mites are running about. More complete descriptions of these and other red spiders will be found on page 16.

\section{CONTROL}

Since no stage of the web-spinning mites is on the trees during the winter, dormant-season sprays are of no value in their control. In the coastal valleys, where control of the brown rot is often necessary, the sulfur sprays used for this purpose should also be adequate for keeping the mites in check. Otherwise it is better to delay the spraying until after the fruit has been picked and then to spray the trees very thoroughly with $1 \frac{1}{2}$ gallons of oil emulsion, or with 2 gallons of lime-sulfur solution, or 3 to 5 pounds of colloidal sulfur, to 100 gallons of water. If the brown mite is present, it may be controlled 
with a dormant-season spray containing 3 or 4 percent of oil emulsion, as used for scale insects, or by means of the summer sprays just mentioned.

\section{Cherry Fruitfly}

The maggots of the cherry fruitfly (Rhagoletis cingulata Loew) are very injurious to cherries in western Oregon and Washington. They have also been found in parts of Idaho, eastern Oregon, and in Spokane, Wash., but have not become numerous in these localites. The injury is especially severe in years when the cherry crop matures late, since a late season apparently delays the fruit more than it delays the flies, and gives them the opportunity to infest the main crop of cherries. In normal years the maggots live chiefly in seedlings and late varieties. The young maggots begin to feed about the cherry pit, and the flesh of an infested cherry may be separated from the pit very easily, which cannot be done with a cherry that is not infested. This feeding may be done before there are any

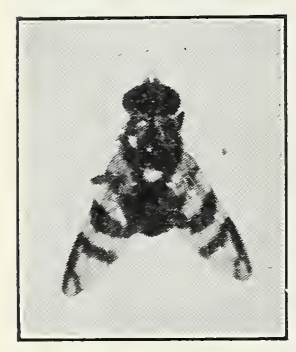

FigURE 55.--Cherry fruitfly. $\times 5$. outward signs of infestation, and often before the maggots are large enough to be seen easily. Later on the cherry begins to shrivel on one side, the flesh is found to be more or less decayed, and small holes appear in the skin. At this stage the white, nearly full-grown maggot may readily be found in the fruit; usually there is only one, but sometimes two or more. The maggots are more easily seen in the dark-meated varieties of cherries such as the Lambert and the Late Duke, and the impression that white cherries are not seriously infested may be gained. However, careful examinations have shown that the white cherries are often infested just as much as the black ones. The infestation at times amounts to 75 to 90 percent of the crop. This insect is a native of the Eastern States.

\section{LIFE HISTORY}

The maggots pass the winter in the soil, in small, hard, brown cases known as puparia. These are produced by the shrinking and drying of the outer skin of the maggot. The flies (fig. 56) emerge from the ground during June or July, and fly about in the sun for some days, feeding on any moisture or honey dew that may be on the trees. After a few days the females lay eggs in the cherries, piercing the skin of the fruit with their ovipositors and depositing the eggs in the flesh. The very small white maggots hatch in a week or less and immediately begin to feed about the pit. Feeding continues for about 2 weeks, and when fully grown the maggots, which are about one-fourth of an inch long, drop to the ground and form their puparia a few inches beneath the surface. They remain there until the following spring.

\section{CONTROL}

Thorough cultivation undoubtedly destroys some of the puparia in the soil, but it does not reach enough of them to be of much value. Since the maggots hatch within the fruit and are protected by it while 
feeding, there is no satisfactory means of poisoning them. An effective control measure can be employed only during the short period when the flies are feeding on honeydew and other moisture before laying their eggs. At this time a sweetened poison bait, sprayed on the trees, very materially reduces the number of flies and consequently the number of infested cherries. A formula that has given satisfactory results in western Oregon is:

Lead arsenate

$1 / 2$ pound.

Molasses or sirup

2 quarts.

Water. 10 gallons.

Any cheap molasses or sirup may be used, but honey should not be used, as it attracts honeybees to the bait, and many of them may be killed. This spray should be applied in the form of fine droplets to the upper surface of the outer leaves, and seedling cherry trees and foliage of other nearby trees should also be sprayed. It is not necessary to spray the trees thoroughly, as the flies are active and will find the bait readily. The fruit should not be sprayed any more than necessary. In large orchards a power spray outfit may be used, and it should be thoroughly cleaned out before the bait is put into it.

Two or three applications of bait should be made at intervals of about 1 week. If a heavy rain occurs shortly after the bait is put on, the application should be repeated as soon as the trees are dry.

The proper time to begin using this bait is early in June. Since the time differs in different localities and in different seasons, local authorities should be consulted about it.

\section{Pear Slug}

The pear slug (Caliroa cerasi (L.)) is sometimes called the cherry slug, as it frequently skeletonizes the leaves of cherry trees. If it is not controlled, the trees may be almost completely defoliated, as the skeletonized leaves die and drop off. This condition seriously affects the development of fruit buds for the following year's crop. The slugs may be controlled on cherry trees in the same manner as on pear trees. Control measures and the life history are given on page 43 .

\section{Syneta Leaf Beetle}

The syneta leaf beetle (Syneta albida Lec.) is a very common pest of the cherry west of the Cascade Mountains. It also attacks the apple, pear, plum, prune, small fruits, and various shade and nut trees. It is apparently a native insect that has found congenial living conditions in cultivated orchards. The beetles injure the fruit of the cherry when it is immature (fig. 57), eating patches of the skin and parts of the flesh. This injury causes scars and deformities on the mature fruit. The beetles also feed on the stems, causing some of the fruit to drop, and on the buds, blossoms, and leaves.

\section{LIFE HISTORY}

The beetles emerge from the ground just before the trees begin to bloom, usually appearing in considerable numbers during the first warm days about that time. They are about one-fourth of an inch 
long, and light gray, dirty white, or yellowish (fig. 58). They begin feeding in the trees at once and may be found in the orchards for about 2 months. For the most part they remain quietly between the buds or among the foliage but fly out in warm weather if the trees are shaken or sprayed. Eggs are simply dropped to the ground, where

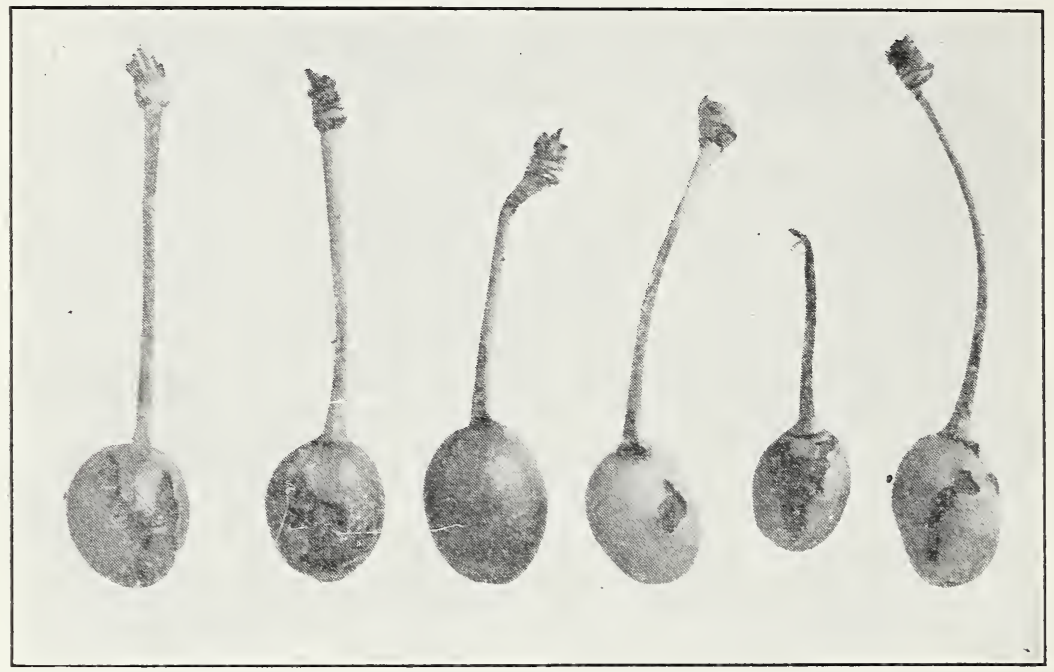

FIGURE 57.-Immature cherries injured by syneta leaf beetle.

they are very difficult to find because of their small size. The eggs hatch in 2 or 3 weeks, usually just after a rain or in damp weather, as the young grubs find it difficult to survive in dry soil. The grubs burrow into the ground, where they feed on the fine fibrous roots of the trees and in this way do a certain amount of damage. Feeding continues throughout the summer and fall.

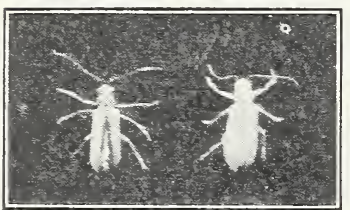

Figure 58.- Syneta leaf beetles, male and female. About $\times 1 \frac{11}{1}$. The grubs remain in the soil during the winter, forming small cells early in the spring. Within these cells they change to pupae and then to beetles.

\section{CONTROL}

The injury caused by the beetles may be greatly reduced by spraying the trees twice very thoroughly with lead arsenate at the rate of 4 pounds to 100 gallons of water. The first application should be made just before the blossoms open, that is, when the tips of the white petals are beginning to show, and the second just after the petals have dropped. In severe infestations a third application may be made as soon as the husks have fallen. The application made just after blooming is the most effective of the three, and if the trees are sprayed only once, the spraying should be done at that time. Fungicides for controlling brown rot may be used with any of these sprays. 


\section{Pear Blight Beetle}

Cherry trees are sometimes attacked by the pear blight beetle (Anisandrus pyri Peck), which makes small round holes in the trunks. For a description of this insect and its habits, and for methods of preventing its attacks, see page 36 .

\section{Pear Thrips}

The pear thrips (Taeniothrips inconsequens (Uzel)) is sometimes injurious to cherries in western and northeastern Oregon and in southeastern Washington. Its habits and control on cherry trees are much the same as on prune trees (p. 57).

\section{PRUNE AND PLUM INSECTS}

\section{SaN Jose Scale}

The San Jose scale is a very important pest of prune and plum trees. For description and treatment see pages 9-12.

\section{European Fruit I،ecanium}

The European fruit lecanium, or brown apricot scale (Lecanium corni Bouché), seldom appears in the irrigated valleys but is sometimes common elsewhere. It is a relatively large, hemispherical, brown, more or less wrinkled scale insect (fig. 59) occurring on the twigs and limbs of prune, apricot, and peach trees, and also on other fruit and shade trees, including pear, apple, cherry, quince, alder, ash, boxelder, locust, poplar, and willow. It passes the winter as a nearly mature insect, laying eggs beneath the shell in the spring. These hatch from May to July, and the young settle on the twigs and leaves. There is only one generation a year. This scale may be controlled with the usual dormantseason applications of

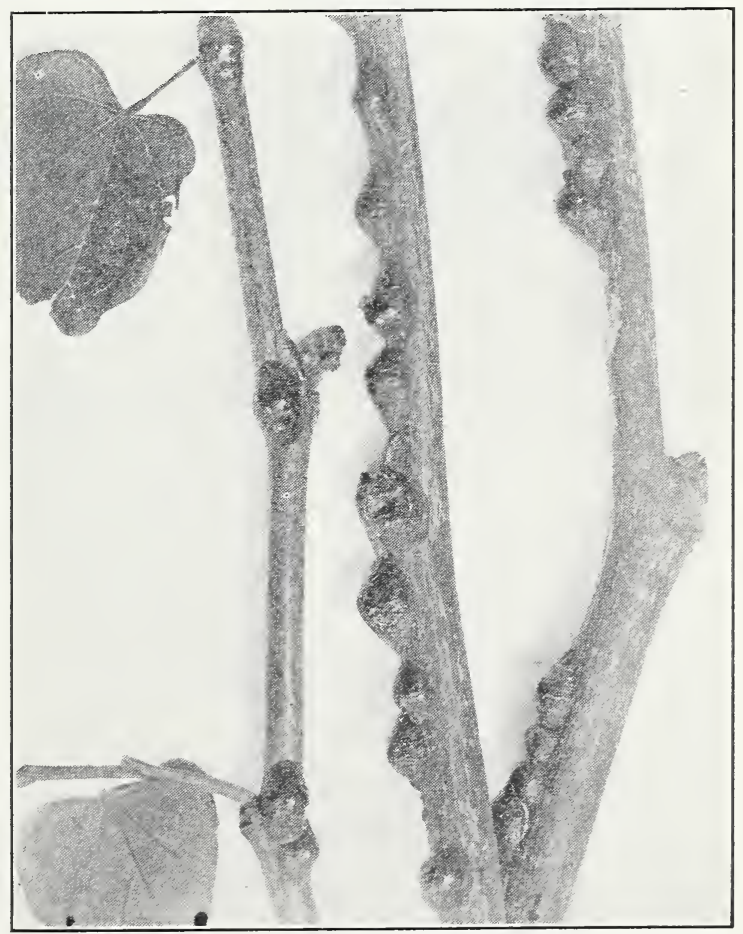

FIGURE 59.--European fruit lecanium. $\times 2$. lime-sulfur or oil emulsions (tables on pp. 71 and 73), the oil being more effective than the lime-sulfur. 


\section{ApHids}

Four or five species of aphids occur on prunes and plums in the Pacific Northwest. All have similar habits and may be controlled in a similar manner. One of the commonest species is the hop aphid

(Phorodon humuli (Schr..)), which is

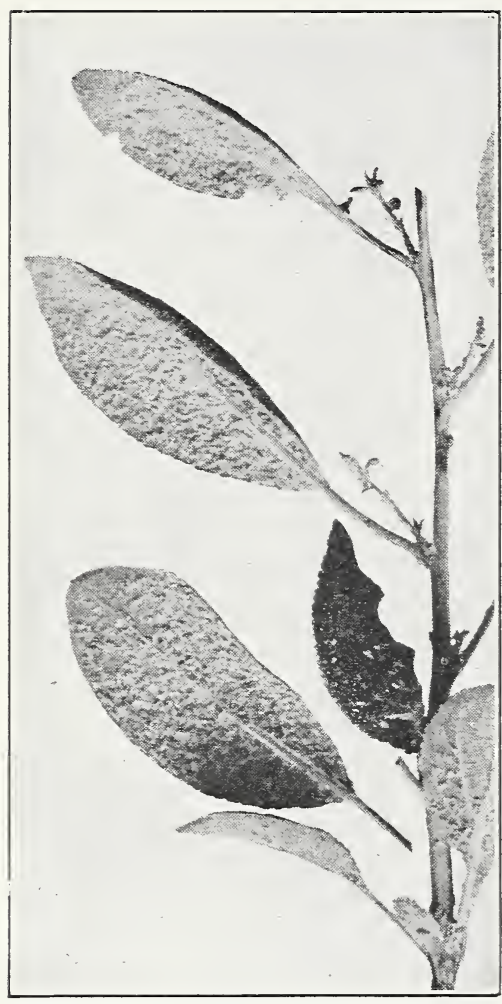

FigURE 60.-Mealy plum aphid on plum foliage. a serious pest of hops, but spends a part of the year on prune trees. Planting hops near prune orchards should therefore be avoided, if possible. This aphid, which is green, often covers the under surface of the leaves of prune trees early in the season. The mealy plum aphid (Hyalopterus arundinis (F.)) may be recognized by its bluish-green color and its whitish, powdery covering (fig. 60). It frequently becomes exceedingly abundant on the under surface of the leaves. The thistle aphid (Anuraphis cardui (L.)), the leaf curl plum aphid (A. helichrysi Kalt.), and the green peach aphid (Myzus persicae (Sulz.)) also occur on prune and plum trees, and occasionally become abundant. These are green or reddish, and they curl the leaves considerably. All of these species are of European origin.

\section{LIFE HISTORY}

The life histories of these aphids are similar. Wintering eggs are laid on the trees and hatch early in the spring before the buds have swelled appreciably, the young feeding within the opening buds and on the leaves. After several generations have developed on the prune trees, winged forms develop and fly to the summer host plants, and later generations return to the trees in the fall. During the summer the hop aphid is found on hops, the mealy plum aphid on reed grasses and cattails, the thistle aphid on thistles, chrysanthemums, and other plants, and the other two species on a large variety of wild and cultivated plants.

\section{CONTROL}

A dormant-season application of oil emulsion, containing 4 percent of oil, is ordinarily fairly effective in controlling aphids on prune and plum trees. If lime-sulfur is used, nicotine sulfate (40 percent nicotine) should be added to it in the proportion of three fourths of a pint to 100 gallons of water. If the dormant spray has not been applied, 
and the infestation becomes serious, a special application of nicotine sulfate may be made at any time it is needed, adding to it 2 or 3 pounds of soap in solution or 1 pound of casein spreader to 100 gallons.

\section{Red Spiders}

Prune and plum trees are often seriously affected by red spiders. The foliage is bronzed and defoliation may occur in nonirrigated orchards, frequently accompanied by the dropping of some of the fruit. Injury by the mites may prevent the fruit buds from forming, or at least may weaken them, causing a small crop or small fruit the following year. This injury is often much more serious than is apparent. All of the three species discussed on page 16 occur on these trees.

\section{CONTROL}

Control is similar to that on apple and pear trees (p. 19). If it is necessary to use sulfur sprays to control brown rot, special applications for red spiders should not be necessary. Summer sprays of oil must be applied before July for the best results. Later applications, besides being less effective, cause the bloom on the fruit to become spotted, and this detracts from its market value. Sulfur sprays do not have this objectionable feature; and if control has not been attained by the 1st of July, sulfur sprays or dusts should be used.

\section{Rust Mite}

The rust mite (Phyllocoptes schlechtendali Nal.) causes prune leaves to curl longitudinally and become russeted or silvered. The fruit may also be russeted. Control is the same on prune trees as on apple and pear trees (p. 22).

\section{PEACH Borer}

Peach borers are very serious pests of prune and peach trees, as well as of apricots and plums and occasionally cherries. The injury occurs chiefly in the crown and roots of the trees, where the borers tunnel beneath the surface, feeding on the inner or growing layer of bark. Young trees may be completely girdled and killed (fig. 61), and older trees are frequently so weakened that they become subject to other insect pests or to diseases. The presence of borers in the trees is often first indicated by a quantity of gum at the base of the trunk, mixed with dirt and frass. Poor condition of the trees may also indicate the presence of the borers. Trees should be examined periodically for borers, especially if they are not making good growth or do not appear to be thrifty. The borers are most commonly found in the region west of the Cascade Mountains, but sometimes become injurious elsewhere.

\section{LIFE HISTORY}

The peach borer (Sanninoidea exitiosa (Say)) and the western variety of the same species (S. exitiosa opalescens (Hy. Edw.)), formerly considered a distinct species, are both found in the Pacific Northwest. The adult is a steel-blue moth with a wing expanse of 
more than an inch. The wings of the male moth are clear, except for the margins, but the fore wings of the female are opaque. The female of the eastern form has an orange band about the abdomen, while in that of the western variety the whole abdomen is steely blue. The male moth of the eastern form has several narrow yellow bands on the abdomen and yellow markings on the wings; these do not appear

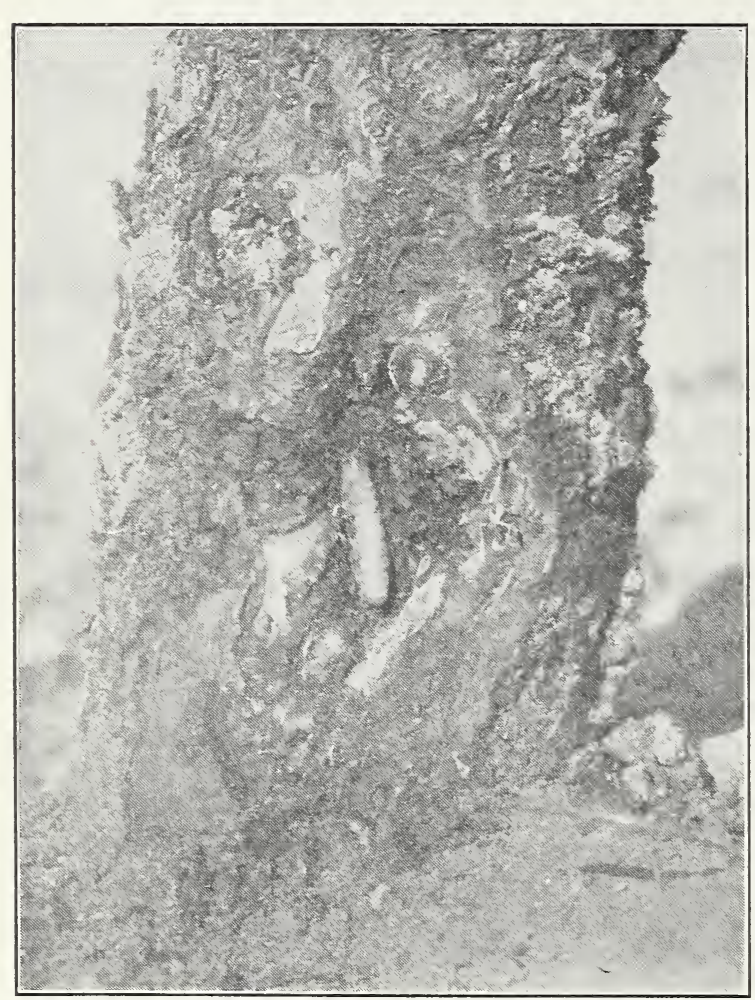

FIgURE 61.-Base of young peach tree severely injured by the peach borer. About $\times 1 / 2$. on males of the western variety. Otherwise the two forms are very similar in appearance and their habits are the same.

The moths appear in the orchards in July and August, flying about very actively during the warm part of the day. Each female lays several hundred oval, cinnamon-brown eggs, singly or in groups on the tree trunks. The eggs hatch in about 10 days, and the young borers crawl down the trunks and enter the damp bark just beneath the surface of the soil. They at once begin feeding on the inner bark and continue doing so until late in the fall, remaining quietly in the burrows during the winter. In the spring feeding is resumed, and the borers become full grown in May and June, when they are about 1 inch long, yellowish white or cream-colored, with brown heads. They construct cocoons of silk and frass at the surface of the soil, either in the tunnel or close to the trunk, within which they change to pupae and several weeks later to moths. There is only one generation annually.

\section{CONTROL}

The peach borer was formerly combated by "worming" the trees. The soil was removed from about the trunk, the tunnels of the borers were located by means of the exuding gum, and the borers were cut out and destroyed. This had to be done early in the spring or late in the fall to be effective, and was a rather slow, tedious method, accompanied by some injury to the trees in addition to that occasioned by the borers. A cheaper, easier, and more effective control measure is 
to place paradichlorobenzene ("PDB") about the tree trunks in the fall. This chemical is in the form of white crystals having a characteristic odor a little like that of naphthalene, and forming a gas that is heavier than air. When properly used, paradichlorobenzene kills practically all of the borers without injuring the trees, and is not harmful to man or animals.

After the ground has been leveled off, the paradichlorobenzene should be placed about the tree trunk in a ring about $1 \frac{1}{2}$ inches from the trunk and 1 or 2 inches wide (fig. 62), using from $3 / 4$ to 1 ounce of the crystals to each tree, depending on its size. Care should be taken not to place the crystals in contact with the tree trunk as they may injure the tree, and not to make the ring more than 2 inches from the trunk, as it would not be so effective at a greater distance. The ring of paradichlorobenzene should be covered with several shovelfuls of earth, which should be packed down with the back of the shovel. The paradichlorobenzene should be applied between August 15 and September 15. At this time the borers are small and easily killed. Later, cold weather may hinder the formation of gas from the crystals, as this process requires a soil

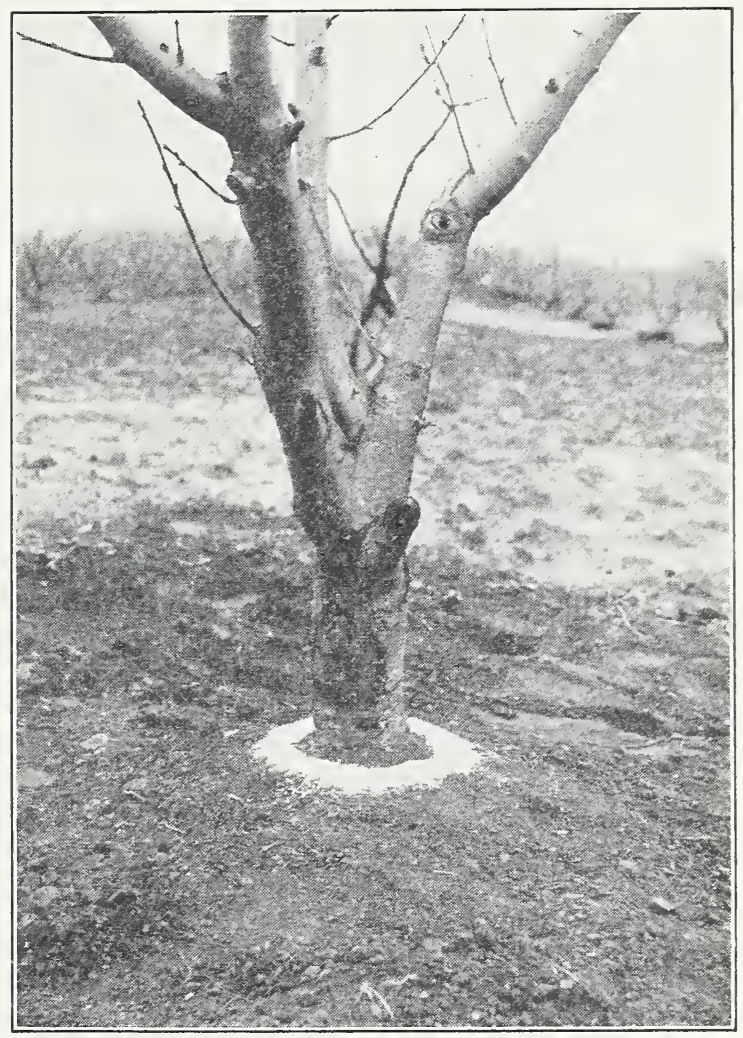

FIGURE 62.-Correct method of placing paradichlorobenzene for controlling the peach borer.

temperature of at least $60^{\circ} \mathrm{F}$. To prevent any possible injury to the trees from the gas, the remaining crystals of paradichlorobenzene should be scattered away from the tree with a shovel a month or 6 weeks after they are applied. If paradichlorobenzene is to be kept for a time, it should be stored in airtight containers to prevent loss by evaporation.

During the past few years a new material has been found of value in peach borer control. This is an emulsion of ethylene dichloride applied to the soil around the base of the tree. This material has the advantage of being more effective than paradichlorobenzene at low temperatures and of being less likely to cause injury to young trees. 


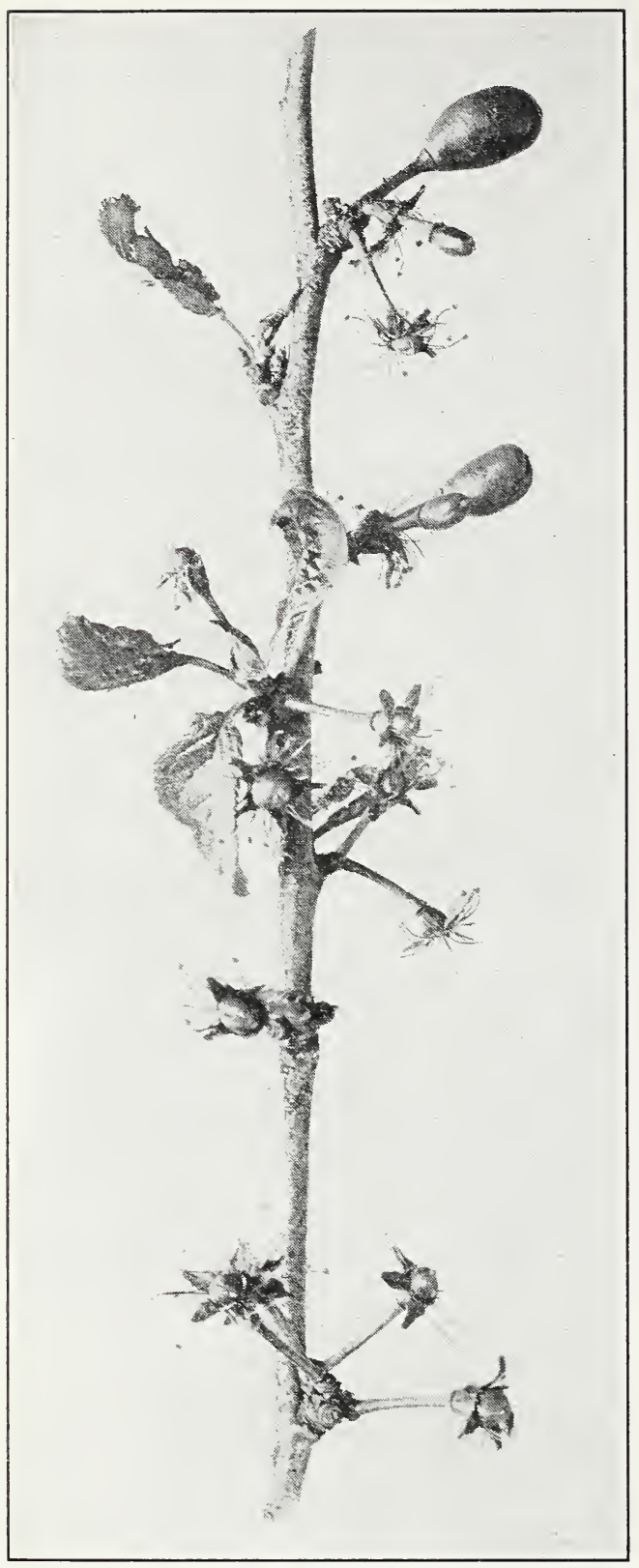

FIGURE 63.-Prune twig showing deformed leaves and poor set of fruit caused by the pear thrips.
It is being used very extensively in the East and to a limited extent in the Northwest. Detailed information on it may be obtained by writing to the Agricultural Experiment Station of the State in which the orchard to be treated is located or to the United States Department of Agriculture.

\section{Other Borers}

Flatheaded borers are often found in the trunks of prune trees, particularly in trees not in the best condition. A darkened area of bark is an indication that the borers may be present. The pear blight beetle is another insect that attacks unhealthy trees, making round, shotlike holes in the trunks. These pests are discussed on pages 35 and 36 .

\section{Pear Thrips}

The pear thrips (Taeniothrips inconsequens (Uzel) causes more injury to prune trees in the Pacific Northwest than to pears or other fruits. The insect occurs in western and northeastern Oregon, in southeastern Washington, and in western British Columbia. It has apparently been introduced from Europe. There are three types of injury. The most serious injury is caused by the adult thrips, which emerge from the ground in the spring, feed in the developing buds, and produce deformed leaves and blossoms (fig. 63), thus causing a reduction of the crop. Later the adults lay eggs in the stems of the fruit and foliage. Both the young and the adults feed by rasping the surface and then sucking out the plant juices. 


\section{LIFE HISTORY}

There is only one generation of the pear thrips annually. The adults, which are small, less than one-twentieth of an inch long, slim and dark brown, emerge when the fruit buds are swelling and beginning to show green. After a feeding period of about 3 weeks the egg-laying period begins, and this lasts another 3 weeks. The eggs are very small, whitish, and kidney-shaped, and they hatch in less than 2 weeks. The young are white and similar to the adults in shape (fig. 64). They develop for about 3 weeks, then drop to the ground, burrow into the soil, and construct small cells a few inches to 3 feet from the surface. Here they remain dormant, changing late in the fall to adults, which emerge the following spring. The pear thrips is thus active on the trees for only about 2 months in spring and is dormant in the ground the rest of the year.

\section{CONTROL}

The pear thrips may be controlled by thoroughly spraying the trees during the first warm weather after the buds have begun to show green. Later sprays may be needed when the blossom buds begin to show white and just after blooming. The trees should be examined some days after the first spray has been applied; if there is an average of one or more thrips to each bud at this time, the later sprays are advisable. For prune and plum trees an oil emulsion or a miscible oil suitable for dormant spraying (p. 73) should be used, 2 gallons to 100 gallons of water, to which is added 1 pint of nicotine sulfate (40 percent

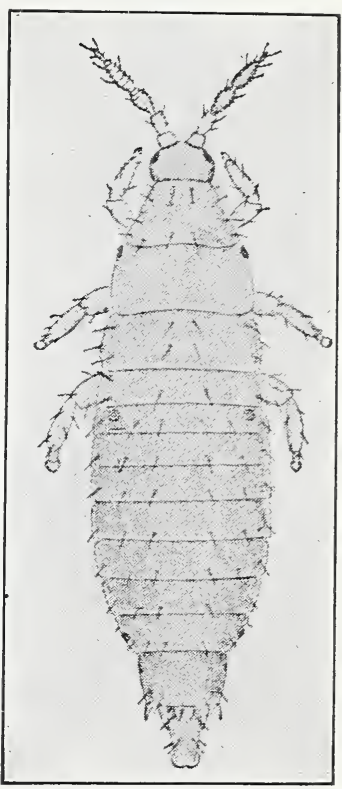

Figure 64.--Larva of pear thrips. $\times 50$. nicotine). Control by cultural means - has not been successful, because many of the young are too deep in the ground to be reached by cultivation.

\section{Eye-Spotted Budmoth}

The eye-spotted budmoth (Spilonota ocellana (D. and S.)) does damage mainly to prunes and plums in the Pacific Northwest, but may be found on all of the orchard fruits, as well as on some other plants. It is a cool-climate insect, occurring chiefly in Oregon and Washington west of the Cascade Mountains, in northern Idaho, and in British Columbia. It is also a pest in the Eastern States, in Canada, and in Europe, which was its original home. As indicated by its name, it causes the most injury to the expanding buds, which are devoured by the partly grown, hungry caterpillars that have hibernated on the trees. Crops are reduced by this bud-feeding habit, and injury to the terminal shoots causes a bushy growth (fig. 65). Later the insects eat the foliage, and a new generation feeds more or less on the fruit, often attaching a leaf to it and feeding in the shelter thus formed. 


\section{LIFE HISTORY AND HABITS}

The partly grown dark-brown larvae of the budmoth pass the winter in small silken nests, or hibernacula, attached to the twigs, often in a crevice or crotch. These nests are made of pieces of leaves or bark held together with silk and are difficult to find on the trees. The

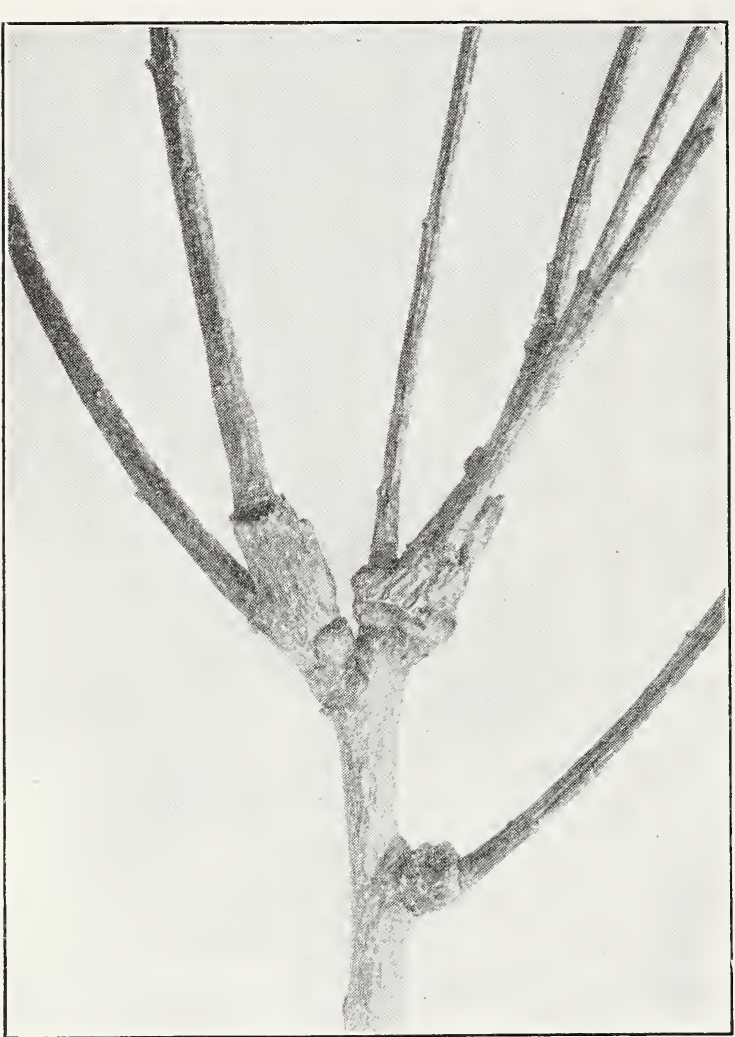

FiguRe 65.-Bushy terminal growth of prune caused by budmoth injury. larvae leave them in April, or whenever the buds begin to swell appreciably, and burrow into the expanding buds and into the terminal shoots, feeding from the inside. Nests of silk are formed in the opening leaves, and as the foliage surrounding them dries the larvae go outside to eat leaves or blossoms, retiring to the nests when not feeding. These webbed nests are often the first indication of the presence of the insects. The larvae become full-grown in June or early in July, when they are olivebrown with black heads (fig. 66, A). They transform to pupae in the nests of webbed leaves, and the moths appear about 3 weeks later. These are somewhat smaller than codling moths, ashy gray, with a cream-white band across both wings (fig. 66, B). The flattened eggs, similar to those of the codling moth, are deposited on the leaves and hatch in a week or so. The young larvae feed on the leaves, protecting themselves with silk, and often eat small holes in the fruit. In the fall these larvae build the hibernacula in which they spend the winter. There is only one generation a year.

\section{CONTROL}

A spray of lead arsenate, 3 pounds to 100 gallons of water, should be applied just as the tips of the leaves are pushing out of the buds. If the infestation is serious, a second application may be made a week or 10 days later. 


\section{Lesser Appleworm}

The lesser appleworm (Grapholitha prunivora (Walsh)) has recently been discovered in eastern Oregon where it has been causing considerable injury to prunes. It has also occurred for some years in British Columbia, and is known as a serious pest of apple in sections of the eastern parts of the United States and Canada. The egg, larva, and adult moth are somewhat similar in appearance to the corresponding stages of the codling moth, except that they are smaller, and the habits of the insect are also similar. Control in the East has been much the same, but it is not certain that it would be safe to use lead

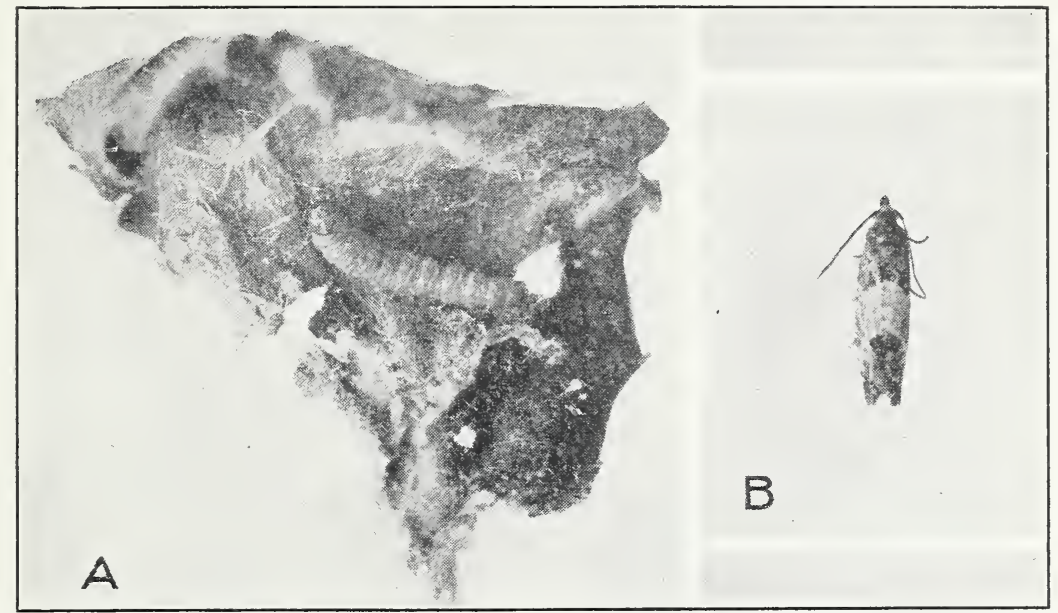

Figure 66.-A, Full-grown larva of eye-spotted budmoth; B, eye-spotted budmoth. About $\times 2 \frac{1}{2}$.

arsenate on prunes, and one or two thorough applications of nicotine sulfate and summer oil emulsion, as used for aphids, and applied in May or early in June, are suggested.

\section{Destructive Prune Worm}

The destructive prune worm (Mineola scitulella Hulst) has been injurious only in southern Idaho, where it has become a rather serious pest of prune trees. Its habits are somewhat like those of the bud moth. The partly grown brown worms spend the winter in small hibernacula woven of silk and placed in the smaller crotches or in crevices in the bark. These worms emerge in the spring before the flower buds are open and bore into the buds, feeding entirely on the inside and destroying many blossoms. They become full-grown in 2 to 4 weeks, when they drop to the ground and spin loose cocoons. The moths emerge from these cocoons in June and lay eggs singly on the lower surface of the prune leaves. The worms hatching from these eggs burrow into the green prunes and cause considerable injury by feeding on the fruit. This second brood of worms becomes full-grown late in July or early in August and produces a second brood of moths. 
Worms coming from eggs laid by these moths feed for a time in the maturing fruit and then leave it and spin the silken nests in which they hibernate. There are thus two complete generations in a season. No satisfactory measures for controlling this pest have been worked out.

\section{SNowy Tree Cricket}

The snowy tree cricket (Oecanthus niveus (Deg.)) occurs throughout the Pacific Northwest, but is of economic importance only in southern Idaho, where it does considerable harm to prunes by eating holes in the ripening fruit. Early in the season the young feed on the foliage, but this injury is of little consequence. About the first of August the

prunes are sufficiently ripe to

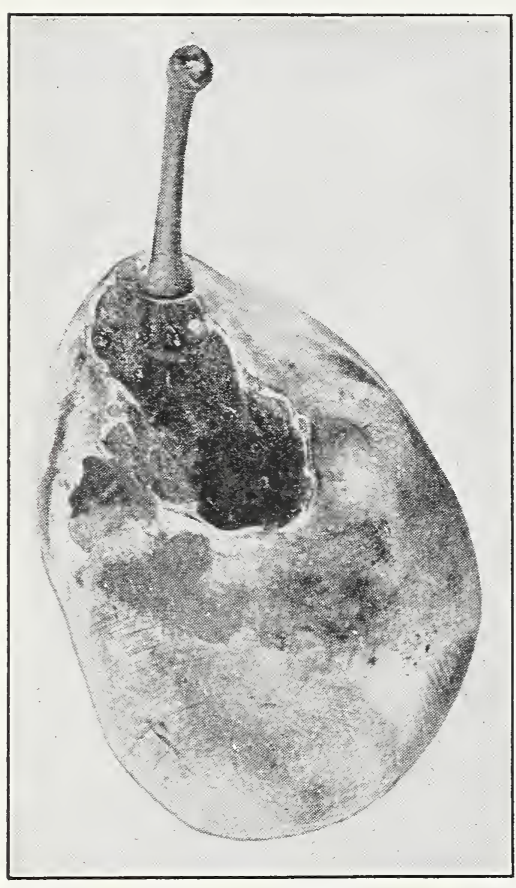

FIGURE 67.-Prune injured by snowy tree cricket. attract the crickets, and after that time both young and adults feed on them instead of on the foliage. Small holes are made in the skin of the fruit, and the flesh is eaten out, large cavities often being formed (fig. 67).

Much of the injured fruit drops prematurely and the remainder is unfit for market. It is impossible to sort out all of the slightly injured prunes; and if any of these are packed, they are very likely to rot and cause a considerable loss in the packed product. The tree cricket also occurs on apple and other trees and on shrubs. The usual program of spraying for the codling moth prevents the tree cricket from becoming injurious to apples, and it has not caused noticeable injury to any other crops.

\section{LIFE HISTORY}

The eggs are laid in the fall in punctures in the bark of prune and other trees, where they remain through the winter. They hatch late in May or in June, and the young nymphs, which are light green or white, feed on the foliage of fruit trees and cover crops for about 6 weeks, molting at intervals and increasing in size. After molting five times the crickets are fully grown. The adults are slightly more than one-half inch long, light green or yellowish. The female (fig. 68) has narrow, transparent wings, and the male has somewhat broader wings. There is but one generation a year, and the adults may be found in the orchards from July until frost occurs. 


\section{CONTROL}

The injury caused by the snowy tree cricket may very largely be prevented by poisoning the crickets while they are still feeding on the leaves and before they have begun to eat holes in the fruit. In southern Idaho this may be done between July 15 and August 1. The trees may be sprayed with lead arsenate, 2 pounds to 100 gallons of water, to which is added 1 pound of casein spreader. Or they may be dusted with calcium arsenate, using about 1 pound to eight trees.

\section{Syneta Leaf Beetle}

The Syneta leaf beetle (Syneta albida Lec.) ordinarily does not injure prunes so severely as it injures pears and cherries (pp. 39 and 49). Most of the prunes grown in the area inhabited by the beetle are sold in the dried form and the smaller injuries are of less consequence than those on fruit that is to be marketed green or fresh. The injuries result in russeted areas on the prunes. These areas, when large, detract from the appearance of the dried product (fig. 69) and make the fresh fruit unmarketable.

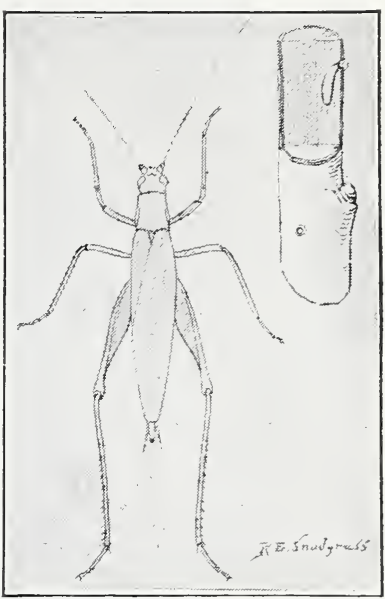

Figure 68.- Snow y tree cricket, female, $\times 2$, and section of twig, showing egg.

\section{CONTROL}

Lead arsenate, 3 or 4 pounds to 100 gallons, should be used for controlling the beetle on prunes. It is most effective if used just before and just after the blooming period, and it may be added to

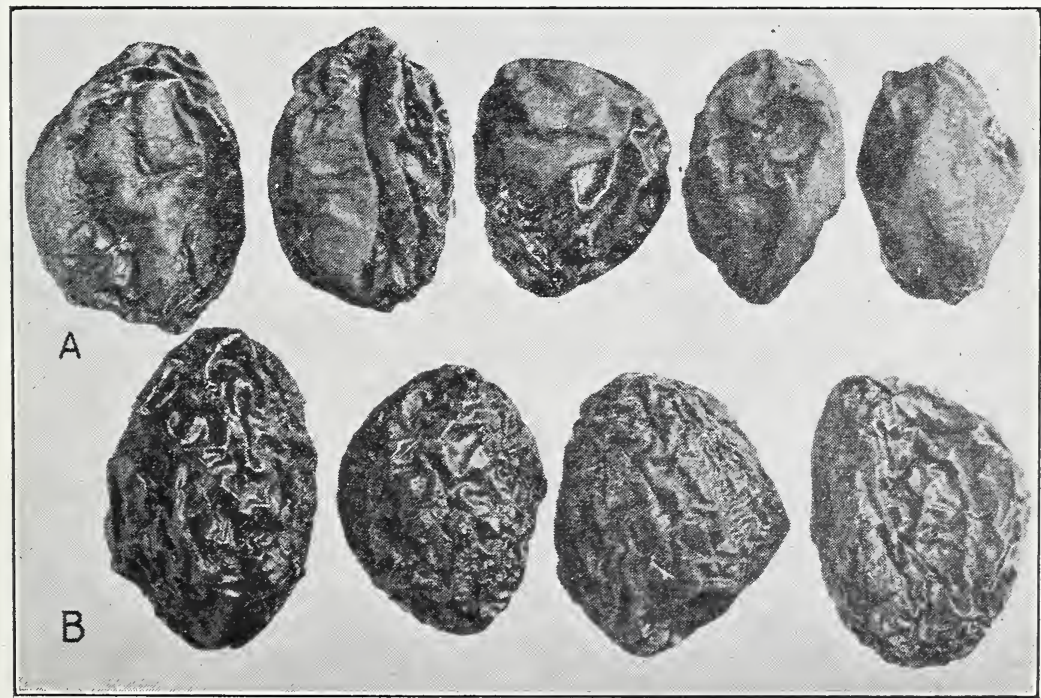

Figure 69.-Dried prunes: A, russeted by syneta leaf beetle; B, uninjured. 
the fungicides used at that time for the control of brown rot. A third application, when the husks have fallen, may be necessary if the infestation is severe.

\section{Caterpillars}

The caterpillars of various moths often become injurious to prune trees in western Oregon and Washington. These caterpillars are most likely to be the tent caterpillars, fall webworms, or caterpillars of tussock moths. A discussion of these insects will be found on pages 39 to 41 .

\section{Peach Twig Borer}

Prune trees are attacked by the peach twig borer in much the same manner as are peach trees. The brown worms bore into the tender new growth, causing the leaves to wilt, and later they feed in the fruit. The life history and control of this pest are given on page 64 .

\section{PEACH INSECTS}

\section{Green Peach Aphid}

A serious reduction of the peach crop is sometimes caused by large numbers of green peach

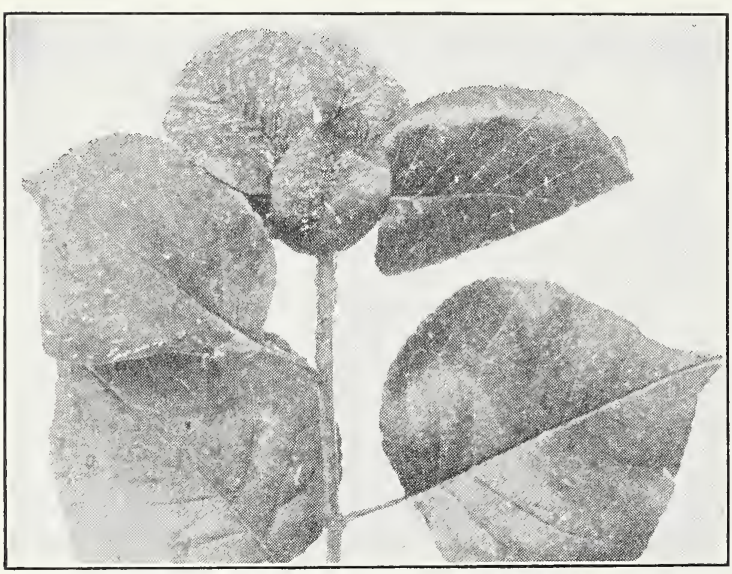

FIGURE 70.--Green peach aphids on pear foliage. aphids (Myzus persicae (Sulzer)) (fig. 70) in the opening blossoms. These sucking insects, by removing the juices from the newly formed fruit, may cause it to drop. They also curl the leaves badly and prevent them from developing normally. It is important, therefore, that control measures be taken early, as little or no injury occurs later on. The green peach aphid came from Europe and is common in all of the peach-growing districts of the West.

\section{LIFE HISTORY}

The glossy black wintering eggs may be found on the twigs, in the axils of the buds, and in the crevices of the bark. They hatch early in the spring, and the pinkish young commence feeding at once on the opening buds, pushing their way into the unfolding blossoms and between the developing leaves. The second and third generations are green, and the latter acquire wings and migrate to summer food plants, which include many of the common vegetables and ornamental plants, such as cabbage, cucumber, lettuce, potato, tomato, turnip, 
carnation, chrysanthemum, snapdragon, and violet. In the fall winged forms return to the peach and produce a wingless generation that lays the overwintering eggs.

\section{CONTROL}

The use of oil emulsions for dormant spraying has simplified the problem of controlling the green peach aphid. An emulsion containing 4 percent of oil, as used for the San Jose scale, affords very good control, if applied just as the buds begin to swell. It must be used after the eggs have hatched and. before the buds have opened. If it is necessary to use lime-sulfur solution for the peach twig borer, nicotine sulfate (40 percent nicotine) should be added to it in the proportion of three-fourths of a pint to 100 gallons of spray, as the lime-sulfur is not effective in controlling the aphids. If neither the oil emulsion nor the limesulfur solution is used, soap $\mathrm{Ol}^{\prime}$ casein spreader should be added to the nicotine spray to increase its power of wetting the insects.

\section{Black Peach Aphid}

The black peach aphid (Anuraphis persicae-niger (Smith)) is seldom seen in the Pacific Northwest, although it does occur in Idaho and possibly elsewhere, having been introduced from the Eastern States, where it is native. It feeds on the roots as well as on the young twigs and leaves of peach and apricot trees, and is therefore potentially a pest of considerable importance, since root-feeding forms are often more difficult to control than those above ground.

\section{LIFE HISTORY}

The black wingless forms live on the roots throughout the year, and in the spring some of them migrate to the new growth above ground, where they increase rapidly (fig. 71). As they become crowded, winged forms develop, which fly to other trees

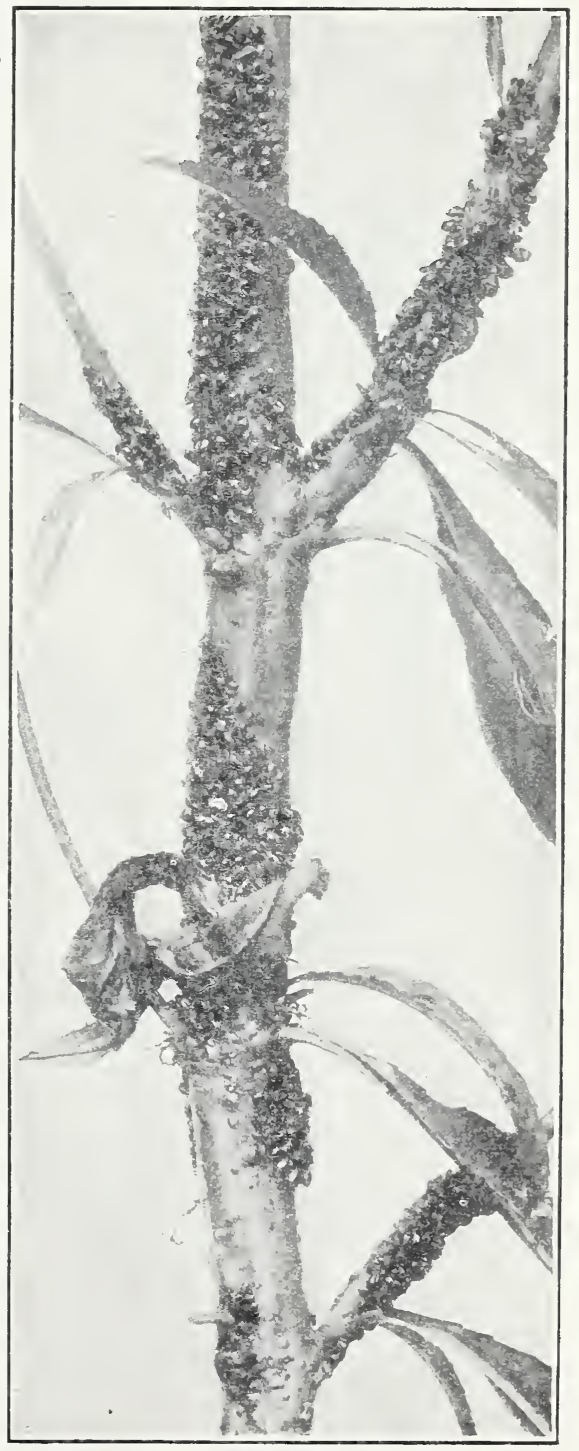

FIGURE 71.-Black peach aphids on peach shoot. 
and establish new infestations. The aerial forms usually disappear by midsummer.

\section{CONTROL}

If the root form is numerous enough to affect the growth of the trees, it should be controlled. This may be done with some effectiveness by using paradichlorobenzene, as recommended for the peach borer (p. 55). The aerial form may be controlled readily with the usual nicotine sprays.

\section{Peach Twig Borer}

Ripening peaches are sometimes wormy, and this worminess may be associated with a split pit. The brown worms in these peaches

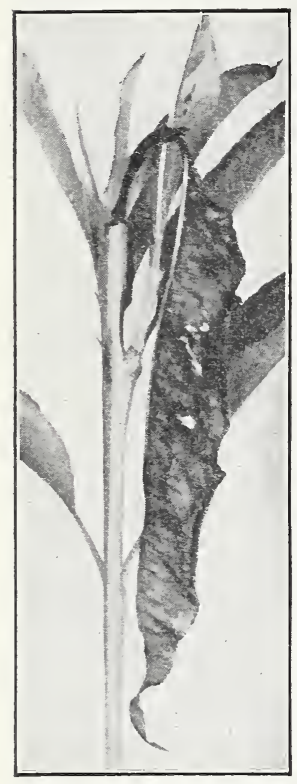

FIGURE 72. - Injury to peach shoot by the peach twig borer. are peach twig borers (Anarsia lineatella Zeller), so named because early in the spring the young worms burrow into the tender terminal growth of the trees and cause the rapidly growing twigs to wilt (fig. 72). The injury is twofold: (1) The development of the new growth is interfered with; and (2) there is a direct loss of fruit. The peach twig borer also attacks prune and apricot trees, and the twig injury is especially serious on nursery trees or in young orchards. The species originated in Europe and has been in the United States for many years.

\section{LIFE HISTORY}

The roung peach twig borers pass the winter in very small silk-lined burrows, known as hibernacula, in the bark. These are usually constructed in the folded bark found in the crotches of the younger branches. Each burrow has a characteristic projecting tube or "chimney," composed of silk and tiny pieces of bark, which is difficult to see without a lens. The small worms leave these winter quarters as soon as twig growth has commenced and burrow into the new shoots, where they feed on the pith and inner bark, thus causing the shoot to wilt. Frequently a single worm injures several twigs in this manner.

By May the worms are mature, nearly one-half of an inch long, and reddish brown. They spin loose cocoons in rough places in the bark or in curled leaves, and the small, inconspicuous, grayish moths emerge in June. These lay minute eggs on the bark, and the tiny worms hatching from them attack the fruit as well as the new growth. They usually burrow into the peaches near the stem end and feed around the pit; or if this is still soft, they enter it and feed on the kernel. This second brood of worms also produces a brood of moths which lay eggs, and the young worms hatching from these build the silken burrows in which the winter is spent.

\section{CONTROL}

The peach twig borer is very easily controlled by an application of lime-sulfur solution as used for the San Jose scale (p. 11). If 
there is no scale infestation, a dilution testing $3.5^{\circ}$ Baumé is adequate (table 1, p. 71) and may be applied at any time in the spring before the pink stage of the blossom buds. Oil sprays are much less effective and should not be used if the twig borer is at all serious. Sprays containing 3 pounds of lead arsenate to 100 gallons of water, or nicotine sulfate (40 percent nicotine) in the proportion of three-fourths of a pint to 100 gallons of water, with soap or casein spreader, are also effective if used just before full bloom, but ordinarily the dormantseason application mentioned above constitutes a cheaper and more satisfactory control.

\section{San Jose Scale}

The San Jose scale is not so serious on peach as on apple and pear, and it seldom injures apricot. For a description of this insect and methods of control, see page 9 . Other insects that may be on the trees at the same time should be taken into consideration, as the limesulfur solution is almost necessary if the peach twig borer is to be combated, whereas control of the green peach aphid requires an oil spray or a spray containing nicotine.

\section{European Fruit LECANIUM}

The European fruit lecanium attacks peach and apricot trees, as well as prunes and other deciduous fruits. For a discussion of the life history and control of this insect, see page 51 .

\section{Climbing \\ Cutworms}

Climbing cutworms often destroy many of the opening buds on peach and apricot trees in the spring (fig. 73). The injury is more apparent than the insects, since the latter feed only at

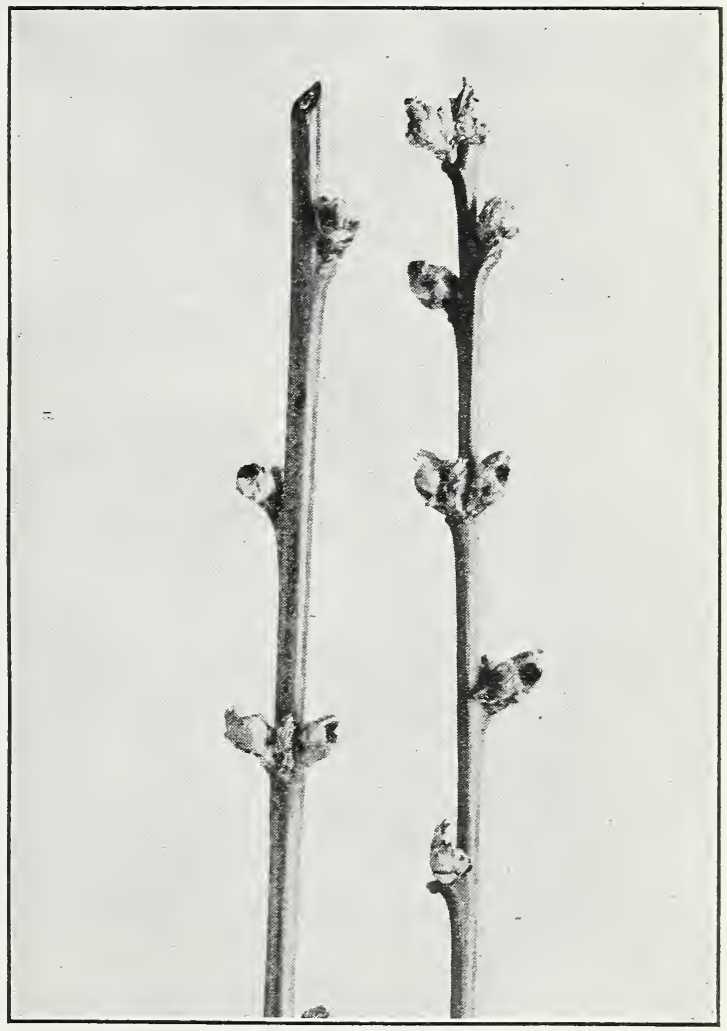

Figure 73.-Peach buds showing holes made by climbing cutworms.

night and hide at the bases of the trees during the day. See page 31 for more information about the insects and their control.

\section{Peach Borer}

Although the peach borer is a serious pest of peach trees in California and the Eastern States, it does more injury to prune trees than to 
peach trees in the Pacific Northwest, and the reader is referred to page 53 for a discussion of this insect.

\section{Stone Flies}

Stone flies or salmon flies (Tatniopteryx pacifica Banks) occasionally injure the buds of peach, apricot, and plum trees in the spring (fig. 74 ), particularly where these trees are growing near the Columbia River or some other large stream. The roung of these insects live in, the streams, and the adult flies emerge early in the spring, when thousands of cast skins from which the flies have emerged may be found among the rocks along the stream banks. The

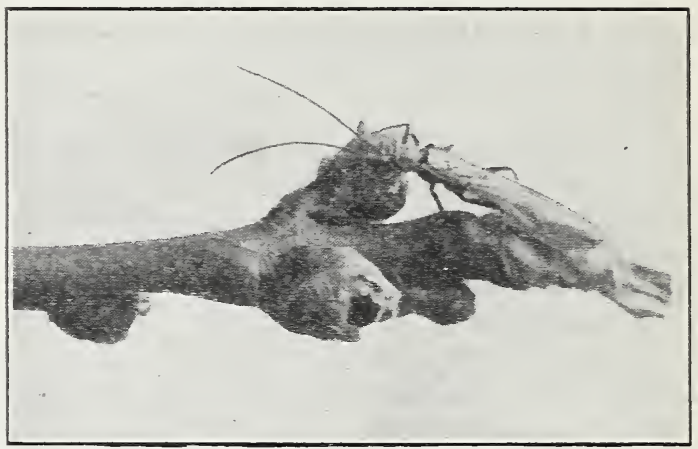

Figtre 74.-Stone fly feeding on peach bud. $\times 2$. flies feed on the fruit buds mostly during warm, sunny weather, destroying many of the buds and injuring others so that they produce deformed fruit. If control is necessary, lead arsenate, in the proportion of 2 pounds to 100 gallons of water, should be effective if applied as soon as the insects appear.

\section{NUT INSECTS}

\section{Filbert Worm}

The filbert worm ${ }^{6}$ (Melissopus latiferreanus (Wals.)) is the most serious pest of filberts in western Oregon and Washington on account of its direct injury to the nuts. It is generally distributed throughout the Pacific Northwest, but causes commercial loss only locally. This worm is the larra of a pale to dusky moth having two coppery bands near the tips of its forewings. Eggs are laid on the leares near the nuts, or on the husks, and the young worms enter the nuts at the base. They mature after feeding for 3 or 4 weeks and leare the nuts to orerwinter in cocoons formed in the ground, in trash, or in dried or rolled leaves on the ground. Pupation occurs from early in May through August. No effectire control measures have been developed.

\section{WaLNut ApHid}

The walnut aphid (Chromaphis juglandicola Kalt.) is the only insect pest of any importance on walnut trees in the Pacific Northwest. It is a small pale-rellow, wingless or winged insect found on the underside of the leares, often in considerable numbers. These aphids secrete a sticky liquid known as honeydew, which corers the leares and nuts, and in which a black fungus grows. Syrphus flies, ladrbeetles, and other natural enemies of aphids (p. 67) usually

${ }^{6}$ Also known as the Catalina cherr moth. 
keep this pest in check so that artificial control is unnecessary. If these beneficial insects fail, the aphid may successfully be combated with nicotine sulfate (40 percent nicotine), $1 / 2$ pint to 100 gallons of water, to which is added soap or spreader, or a 2 percent nicotine dust ( $2 \frac{1 / 2}{2}$ pounds of nicotine sulfate to $47 \frac{1}{2}$ pounds of hydrated lime) may be used.

\section{BENEFICIAL INSECTS}

Not all of the insects found in an orchard are harmful. Many are of no importance, either because they are not sufficiently numerous, or because they are not injuring the trees or the cover crop. Many others are entirely beneficial because they feed on some of the insects that are harmful to the crops. Fruit growers should be able to recognize these beneficial insects in order that they may not destroy them, thinking them to be harmful. The most conspicuous beneficial insects and the ones most often found in an orchard are those that

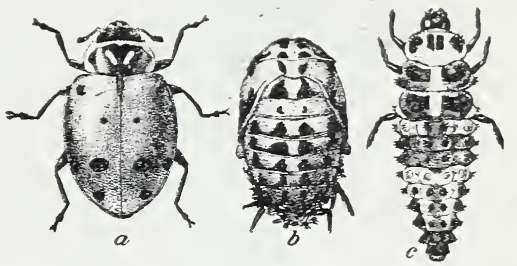

Figure 75.-The convergent ladybeetle: $a$, Adult; $b$, pupa; $c$, larva. $\times 3$. prey on various species of aphids. These insects are very important factors in reducing the numbers of aphids, and their work is most likely to be effective during warm weather when they are active and are multiplying rapidly.

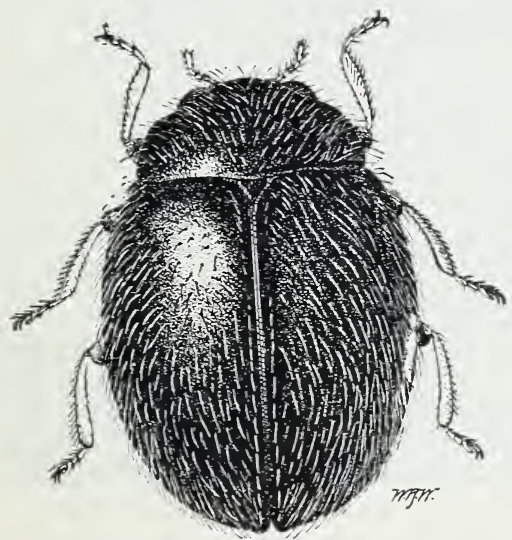

Figure 76.-A ladybeetle, Stethorus picipes Casey, an enemy of red spiders. $\times 40$.

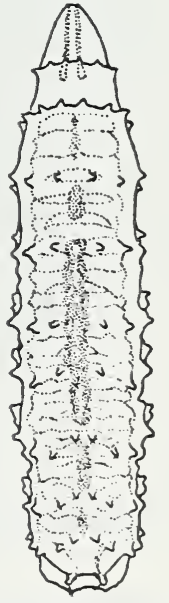

FIGLRE 77.- Larva of a syrphus fly (Allograpta ob̆liqua Say). $\times \tilde{j}$.

Ladybeetles are nearly always abundant in orchards, and the beetles and their young feed on the aphids which may be on the trees or in the cover crops. There are many species, one of the commonest being the convergent ladybeetle (Hippodamia convergens Guér.) (fig. 75), a red beetle with black head and black spots on the back. Some species are plain red, others are black with two or more red spots, and there are also small black ladybeetles (fig. 76) that feed chiefly on red spiders 
and scale insects. Most of these species lay yellow or orange-colored cigar-shaped eggs, which stand on end in clusters. The young, or larvae, are usually black or gray, with various red or orange markings. Some of them are covered with a white waxy secretion, giving them the appearance of mealybugs. Although most of the ladybeetles are con-

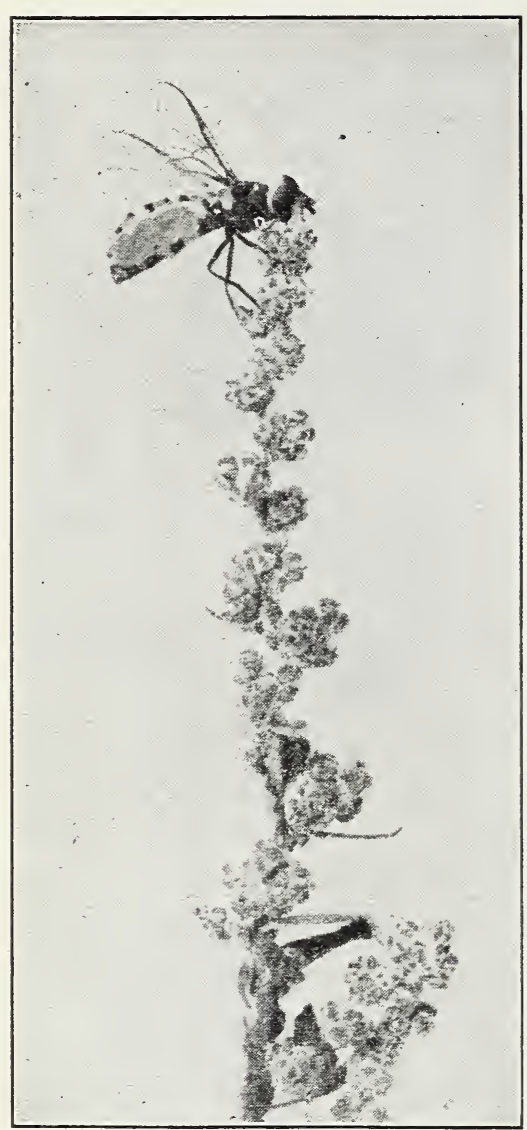

Figure 78.- Syrphus fly killed by fungous disease. $\times 2$. spicuous, they are not molested by birds, possibly because they have a disagreeable taste.

The larvae of syrphus flies are very common enemies of aphids and are most often found in colonies of the woolly aphid. Frequently they destroy the colonies entirely. These larvae or maggots (fig. 77) are nearly one-half of an inch long when full-grown, yellowish or grayish, and often with a stripe down the lback. The body is widest behind, and the narrow head is restlessly moved about as the maggot searches, for food. No legs are evident. The adult syrphus flies (fig. 78) are usually black, striped with yellow, and may be mistaken for wasps or bees. They fly actively and often poise in midair before darting down to a colony of aphids to deposit their eggs. The eggs are elongated, dirty whitish, and are laid singly among the aphids.

The young of lacewing flies (fig. 79) are effective enemies of aphids, and also feed on other insects, such as red spiders, newly hatched codling moth larvae, and the young of leafhoppers. These larvae, which are known as aphis lions, are flat, elongated, tapering at both ends, with long legs and conspicuous sickle-shaped jaws. When mature they are about three-eighths of an inch long, grayish or yellowish, with red or brown markings. They spin spherical white cocoons, which are sometimes found in codling-moth bands, and from which the adults escape by cutting circular lids. The adults are light green with delicate transparent wings and golden eyes. They emit a very disagreeable odor when crushed, and this doubtless protects them from birds and other enemies in the same manner as ladybeetles are protected. The eggs are deposited in clusters, each egg on a long stalk (fig. 80); this is believed to prevent the eggs from being eaten by the young or by other insects.

In addition to the many predacious bugs and beetles that prey on various insects, there are hosts of small, inconspicuous parasitic insects, mostly related to the bees and wasps, that take their toll of the 
pests. Among these may be mentioned Ascogaster carpocapsae Vier., which has been introduced into the Northwest, and which at times parasitizes 25 or 30 percent of the codling moth larvae; Trichogramma minutum Riley, one of the smallest insects, which parasitizes the eggs of the codling moth and other pests; and Aphelinus mali Hald., a parasite of the woolly apple aphid (fig. 81) which has been successfully introduced into the Pacific Northwest.

It is difficult to estimate the amount of benefit done by predacious and parasitic insects. The beneficial species prevent many potentially harmful insects from becoming numerous, and therefore should be encouraged in every way. Frequently, also, outbreaks of serious pests are stopped more completely by beneficial insects than they can be stopped with artificial control measures. Unfortunately the beneficial forms often do not begin to be effective until after the harmful species have done much damage, and the

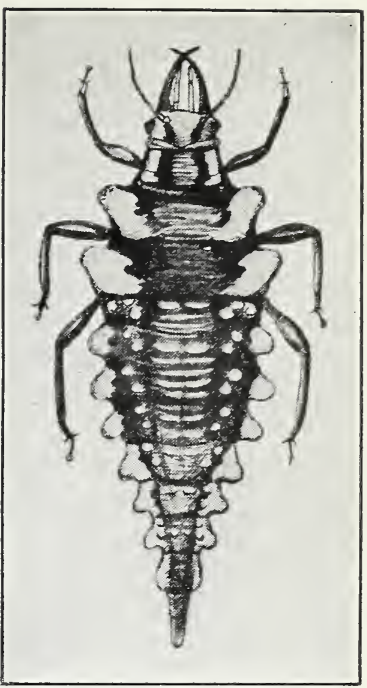

FigURE 79.- Young of a lacewing fly. $\times 6$. fruit grower cannot afford to wait but most control the pests himself. The sprays applied to trees, particularly the contact sprays, may

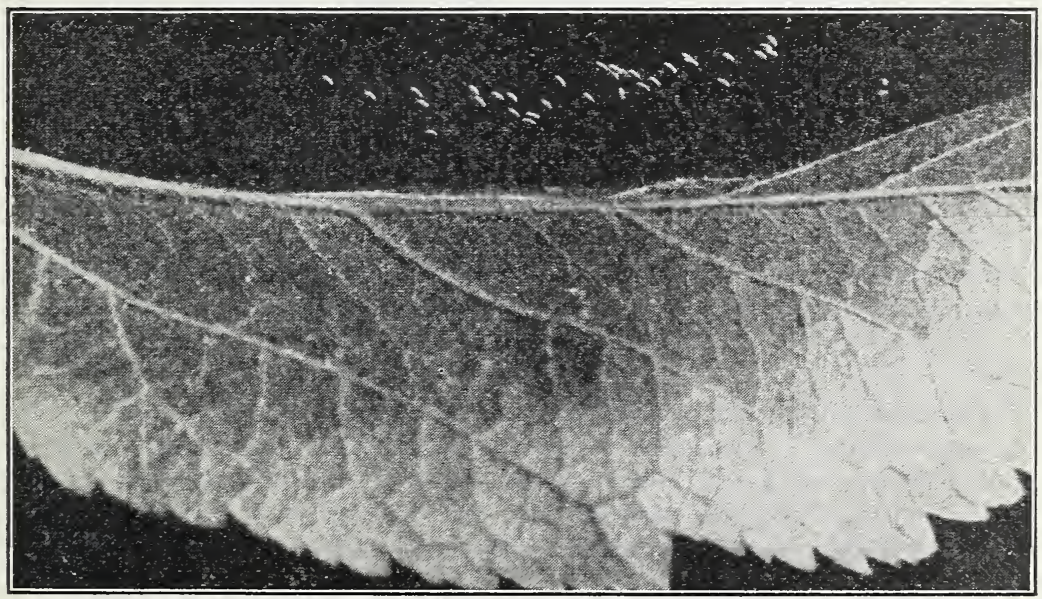

FiguRE 80.--Eggs of a lacewing fiy.

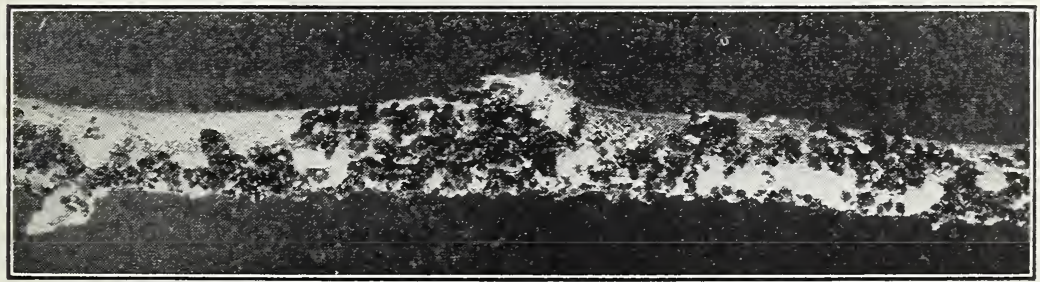

FigUre 81.-Woolly apple aphids parasitized by Aphelinus mali. 
destroy many of the beneficial insects. However, since the adults usually are not harmed, being able to avoid the spray, they are able to return, and they or their young may rapidly complete the destruction of the pests which has not been entirely accomplished with the insecticides.

\section{SPRAY MATERIALS}

Fortunately, most of the insect pests of fruit trees spend at least part of their lives in situations that enable the fruit grower to control them by means of sprays. Annual crops may often be protected from serious insect injury by following certain practices of planting, harvesting, cultivating, and crop rotation, but with fruit trees these methods are usually out of the question. Spraying is expensive, but its cost is small as compared with the value of the crop.

Insects feed in two distinct ways. Some bite off and swallow portions of the fruit or foliage. Many of these biting insects may be destroyed by keeping the trees covered with a poisonous material which the insects eat with their food. The young of the codling moth and other moths, beetles, sawflies, grasshoppers, and crickets are examples of biting insects. Other insects have mouths in the form of a sucking apparatus which they insert into the plant tissue and through which they draw out the plant juices. These insects are not affected by stomach poisons placed on the surface of the leaves or fruit, and it is not possible to poison the plant juices without injuring or killing the plants; therefore materials known as contact insecticides are used for their control. These materials poison the insects through their breathing pores, or by a corrosive action on their bodies. The scale insects, aphids, leafhoppers, treehoppers, and the true bugs are examples of sucking insects. Red spiders also feed in this manner, although they are not true insects.

Several spray materials have been employed so extensively and successfully that they have become standard insecticides. The worth of others has not yet been proven, although they may already be used to some extent. As a rule the fruit grower will find that the standard materials, with known ingredients, are more economical and effective than similar proprietary compounds. Compounds whose ingredients are unknown should be avoided, as they are too often worthless. The Federal insecticide act of 1910 specifies that if any insecticide shipped from one State to another contains arsenic in any form, the total amount of arsenic must be stated on the label; and that if the insecticide contains any inert ingredients, the names and amounts of each shall be stated; or the names and amounts of the active ingredients may be stated together with the total amount of inert ingredients. The various States in the Pacific Northwest have similar laws governing the sale of insecticides within them. Growers should therefore refuse to buy any material offered for sale as an insecticide unless it is properly labeled.

\section{Lead Arsenate}

There is no more effective insecticide for chewing or biting insects than acid lead arsenate. It is a somewhat slow-acting poison, but it adheres more firmly to the fruit and foliage than do other materials, and is therefore effective for some time after it has been applied. The quantities recommended in this circular are for the powdered lead 
arsenate. In this form the poison can be handled and stored readily, if kept dry. Lead arsenate may be combined with oil emulsions, with nicotine solutions, and with lime-sulfur or bordeaux mixture for controlling various insect pests and fungous diseases at the same time. If lead arsenate is combined with lime-sulfur solution, the mixture should be used at once, on account of a chemical reaction which occurs. This reaction may be retarded by putting casein spreader or hydrated lime into the tank first, in the proportion of 1 pound to 100 gallons of spray. If any residue of arsenic or lead is present on the harvested fruit in quantities sufficiently great to constitute a menace to the health of the consumer, it must be removed by washing or wiping before the fruit is sold.

\section{Fluorine Compounds}

Cryolite (sodium fluoaluminate) is the most dependable fluorine compound for use in replacing lead arsenate in spray schedules for the codling moth. This is explained on page 8. Lime-sulfur solution or other materials of high lime content should not be mixed with cryolite. As with lead arsenate, any excessive residue, in this case of fluorine, must be removed by washing before the fruit is marketed.

\section{LiME-SUlfur}

Lime-sulfur solution has many uses in controlling certain insect pests and fungous diseases of fruit trees. It may be used as a dormant spray and also, in a more dilute form, as a summer spray. In the latter case it is valuable chiefly as a fungicide. The strength of the concentrate varies, and should be ascertained from the manufacturer or by means of the Baumé or specific-gravity scale on a limesulfur hydrometer. The quantity of the concentrate required to make 100 gallons of diluted spray for various purposes is shown in table 1. Dry lime-sulfur is sometimes used in order to aroid the need of transporting the heavier liquid material. It has not proved so effective against the San Jose scale as the standard lime-sulfur concentrate.

TABLE 1.-Dilution of concentrated lime-sulfur solutions for various strengths of spray

\begin{tabular}{|c|c|c|c|c|c|}
\hline \multicolumn{2}{|l|}{ Strength of concentrated lime-sulfur } & \multicolumn{4}{|c|}{$\begin{array}{l}\text { Quantity } 1 \text { of concentrated lime-sulfur required to } \\
\text { make } 100 \text { gallons of spray solution }\end{array}$} \\
\hline Degrees Baumé & $\begin{array}{l}\text { Specific } \\
\text { gravity }\end{array}$ & $\begin{array}{l}\text { Dormant } \\
\text { strength } \\
\text { for scale } \\
\left(41,2^{\circ}\right. \\
\text { Baumé) }\end{array}$ & $\begin{array}{c}\text { Dormant } \\
\text { strength } \\
\text { for blister } \\
\text { mite and } \\
\text { twig borer } \\
\text { (31/20 } \\
\text { Baumé) }\end{array}$ & $\begin{array}{c}\text { Early } \\
\text { spring } \\
\text { strength } \\
\text { for scab } \\
\text { and red } \\
\text { spiders } \\
\left(112^{\circ}\right. \\
\text { Baumé) }\end{array}$ & $\begin{array}{l}\text { Spring or } \\
\text { summer } \\
\text { strength } \\
\text { for mildew } \\
\text { and red } \\
\text { spiders ( } 1^{\circ} \\
\text { Baumé) }\end{array}$ \\
\hline $\begin{array}{l}36 \\
33 \\
33 \\
31\end{array}$ & $\begin{array}{l}\text { 1. } 330 \\
\text { 1. } 306 \\
\text { 1. } 295 \\
\text { 1. } 283 \\
\text { 1. } 272 \\
\text { 1. } 261 \\
\text { 1. } 250 \\
\text { 1. } 239 \\
\text { 1. } 218 \\
\text { 1. } 198 \\
\text { 1. } 179 \\
\text { 1. } 160\end{array}$ & $\begin{array}{c}\text { Gallons } \\
91 / 2 \\
10 \\
101 / 2 \\
11 \\
111 / 4 \\
111 / 2 \\
12 \\
121 / 2 \\
131 / 2 \\
143 / 4 \\
161 / 2 \\
183.4\end{array}$ & $\begin{array}{c}\text { Gallons } \\
7 \\
71 / 2 \\
73 / 4 \\
8 \\
81 / 4 \\
81 / 2 \\
91 \\
91 / 2 \\
10 \\
11 \\
121 / 2 \\
14\end{array}$ & \begin{tabular}{c|} 
Gallons \\
$23 / 4$ \\
3 \\
3 \\
3 \\
3 \\
$31 / 4$ \\
$31 / 4$ \\
$31 / 2$ \\
334 \\
$41 / 4$ \\
$41 / 2$ \\
5
\end{tabular} & $\begin{array}{l}\text { Gallons } \\
13 / 4 \\
13 / 4 \\
2 \\
2 \\
2 \\
2 \\
21,4 \\
21 / 4 \\
21,2 \\
23,4 \\
3 \\
31,4\end{array}$ \\
\hline
\end{tabular}

1 All quantities expressed in nearest quarter gallon. 


\section{Lubricating-Oil Emulsions}

Lubricating-oil emulsions are extensively used in the Pacific Northwest for controlling the San Jose scale, red spiders, and leaf rollers, and are also used against the codling moth and other insects. They may be purchased in a form which can be readily diluted with water, or, if the grower desires to prepare his own emulsions, the following formula may be used:

Water
Casein (finely powdered)

Put the water into the spray tank, and, with the pump and agitator running, add the ammonia and then sift in the casein slowly. As soon as the latter has dissolved, which will be almost immediately; add the oil about as fast as it will run from the drum. Be sure to let the oil run in at least this slowly until the agitator is well covered, or a reversed emulsion may result. (A reversed emulsion will not mix with water and cannot be used.) Allow the mixture to be stirred thoroughly by the agitator for a few minutes and then pump it through a piece of spray hose at about 250 pounds' pressure into empty drums for storage until it is used. A second pumping is advisable if the emulsion is to be kept more than a week or so. The emulsion should not be made during freezing weather, but when once made it will stand the ordinary temperatures occurring after March 1. It should be used as soon as possible after making, although it will usually keep for several weeks in closed drums. The cost of making, aside from the cost of the oil, should not be over 2 cents per gallon.

The methods of preparing emulsions for dormant and summer use are the same, except that different oils are needed for the two purposes. The grower should be sure that the proper oil is employed, whether he makes his own emulsions or buys the prepared material. The most important specifications for oils are the viscosity, measured by the rate of flow, and the unsulfonated residue, or degree of refinement. For dormant spraying the oil should have a viscosity of 100 to 120 seconds Saybolt, and an unsulfonated residue of 50 to 70 percent. For summer spraying under most conditions the viscosity of the oil should be 65 to 75 seconds Saybolt ("light medium" or "medium" oil), and the unsulfonated residue should be at least 85 percent. For yellow varieties of apples, such as the Yellow Newtown, the viscosity of the oil should not exceed 55 seconds ("light" oil). When oil emulsion is used with lead arsenate, it should be put into the tank first, and the lead arsenate added just before the tank is full. Combinations of some brands of oil emulsion and lead arsenate may cause a slight burning of the foliage, or the mixture may flocculate or "curd" in the tank. The latter is usually not objectionable and may be advantageous in allowing more of the mixture to adhere to the fruit. Combination sprays should be used immediately after being mixed. If they are allowed to stand, they may undergo changes that will reduce their effectiveness or increase the difficulty of removing spray residues. The manufacturer's directions for mixing should always be 
followed. The quantities of concentrated oil emulsion required to make 100 gallons of diluted spray for various purposes are shown in table 2.

TABLE 2.-Dilutions of concentrated oil emulsions required for various strengths of spray

\begin{tabular}{|c|c|c|c|c|c|}
\hline \multirow{3}{*}{ Oil in concentrate (percent) } & \multicolumn{5}{|c|}{$\begin{array}{l}\text { Quantity } 1 \text { of concentrated oil emulsion required to make } \\
\qquad 100 \text { gallons of spray }\end{array}$} \\
\hline & \multirow{2}{*}{$\begin{array}{l}\text { Dormant } \\
\text { strength } \\
\text { for leaf } \\
\text { roller, } \\
\text { 7-percent } \\
\text { oil }\end{array}$} & \multicolumn{2}{|c|}{$\begin{array}{l}\text { Dormant strength for } \\
\text { scale, red spider, etc. }\end{array}$} & \multirow{2}{*}{$\begin{array}{c}\text { Spring } \\
\text { strength } \\
\text { for } \\
\text { thrips, } \\
\text { 2-percent } \\
\text { oil }\end{array}$} & \multirow{2}{*}{$\begin{array}{l}\text { Summer } \\
\text { strength } \\
\text { for } \\
\text { codling } \\
\text { moth, red } \\
\text { spider, } \\
\text { etc. } \\
\text { 0.8-per- } \\
\text { cent oil }\end{array}$} \\
\hline & & $\begin{array}{l}\text { 4-percent } \\
\text { oil }\end{array}$ & $\begin{array}{l}\text { 3-percent } \\
\text { oil }\end{array}$ & & \\
\hline (1 & $\begin{array}{r}\text { Gallons } \\
71 / 8 \\
73 / 8 \\
73 / 4 \\
8112 \\
93 / 8 \\
103 / 8\end{array}$ & $\begin{array}{r}\text { Gallons } \\
41 / 8 \\
41 / 4 \\
43 / 8 \\
43 / 4 \\
51 / 4 \\
6\end{array}$ & $\begin{array}{r}\text { Gallons } \\
31 / 8 \\
31 / 4 \\
31 / 4 \\
358 \\
4 \\
41 / 2\end{array}$ & $\begin{array}{c}\text { Gallons } \\
2 \\
218 \\
214 \\
23 \\
23 \\
2^{3} / 4 \\
\end{array}$ & $\begin{array}{r}\text { Gallons } \\
7 / 8 \\
7 / 8 \\
7 / 8 \\
11 / 8 \\
11 / 4\end{array}$ \\
\hline
\end{tabular}

1 All quantities expressed in nearest eighth of a gallon.

\section{Nicotine}

Nicotine is a very effective contact insecticide for sucking insects, as it not only destroys insects by coming in direct contact with them but also acts as a fumigant in hot weather, killing insects that do not actually come in contact with the spray. This fumigating action is undoubtedly limited to a very short distance, possibly only a fraction of an inch. For this reason it is advisable to spray with nicotine on calm days when the temperature is above $80^{\circ} \mathrm{F}$., if possible, and under such conditions the quantity of nicotine recommended for cold weather may be reduced. Nicotine is sold in the form of free nicotine and also in the form of nicotine sulfate (40 percent nicotine), the latter being employed chiefly for orchard spraying. Homemade decoctions are likely to be unreliable. If nicotine sulfate is used alone, 2 or 3 pounds of soap dissolved in water or 1 pound of casein spreader should be added to each 100 gallons of water, to cause the mixture to spread better and penetrate any waxy covering of the insects. The soap should be omitted if the nicotine is added to other insecticides, but the spreader may be used.

\section{Pyrethrum}

Pyrethrum is finding some use as a contact insecticide. It has little fumigating action, and is thus likely to be less effective than nicotine in hot weather, but in cool weather it is very useful. It should be diluted according to the manufacturer's directions. 


\section{ROTENONE}

Rotenone is a derivative of certain tropical plants, such as cubé or derris, that is sometimes useful as a contact insecticide. It seems to be particularly effective in controlling some of the red spiders. The manufacturers' directions should be followed in using it.

\section{Spreaders and Stickers}

Some sprays have a tendency to collect in drops and roll off the fruit or foliage, and some are easily washed off by rains. A number of materials may be added to insecticides to overcome these difficulties. Various soaps have been used as spreaders and are very useful in nicotine sprays; but soaps are incompatible with lime-sulfur solution and should not be used with it. Also, when used with standard lead arsenate they have a tendency to produce free arsenic, which may burn the foliage or fruit; although when used at not over one-third of a pound to 100 gallons this injury does not usually occur. Another spreader that has been used very commonly is a mixture of casein and lime, commonly known as casein spreader or calcium caseinate. This is very useful with nicotine or lime-sulfur sprays and in a combination of lead arsenate and lime-sulfur or lead arsenate and oil emulsion. Its use with lead arsenate alone, however, is of doubtful value, as it has a tendency to spread the insecticide too thinly. There are other spreaders containing protein that may not have this disadvantage. Spreaders containing mineral oil are also useful. Fish oil is a very effective sticker for lead arsenate and other poisons, and some fish oils, particularly certain herring and dogfish oils, also tend to spread the insecticide more uniformly.

\section{SPRAYING SCHEDULES}

In the Pacific Northwest extensive spraying schedules for insect control are required only for pears and apples. Ordinarily other fruit trees should be sprayed while dormant, and at other times only if insects become troublesome, as explained in the sections of this circular dealing with the control of the various insects. Apple and pear trees should also be sprayed while dormant, as a rule, for the control of scale insects, red spiders, and other pests that may be on the trees at that time. Delayed dormant and "pink" sprays may also be necessary, especially. if scab or mildew is to be combated. On ascount of the prevalence of the codling moth, summer spraying of apple and pear trees should follow a definite schedule. Suggested schedules are given in table 3 , and the individual grower must determine from his own experience and that of other's which schedule to follow. It is not often necessary to apply separate sprays during the summer for other insects, since these may be ordinarily controlled by modifying the schedule for the codling moth. For example, nicotine sulfate and oil emulsion will control a number of other insects. and this com- 
bination may be substituted for almost any of the cover sprays, as it also constitutes an excellent control for the codling moth. In this manner the cost of additional sprays is avoided.

\section{TABLE 3.-Codling moth spray schedules for apples and pears in the Pacific Northwest}

\begin{tabular}{|c|c|c|c|}
\hline \multirow{2}{*}{ Schedule } & \multirow{2}{*}{ Spray } & \multicolumn{2}{|c|}{ Time of application } \\
\hline & & On apples & On pears \\
\hline Schedule $1_{--}$ & 1. Calyx spray & When most petals have fallen & $\begin{array}{l}\text { Just before worms begin to } \\
\text { hatch (combined calyx and } \\
\text { cover spray). }\end{array}$ \\
\hline Schedule 2.. & $\left\{\begin{array}{l}\text { 2. Cover spray } \\
\text { do }\end{array}\right.$ & 4 weeks after $1 . \ldots$ & $\begin{array}{l}\text { When most petals have fallen. } \\
3 \text { or } 4 \text { weeks after } 1 \text {. }\end{array}$ \\
\hline Schedule 3.- & $\left\{\begin{array}{l}\text { 1. Calyx spray } \\
\text { 2. First-brood cover spray } \\
\text { 3. Second-brood cover spray }\end{array}\right.$ & $\begin{array}{l}\text { When most petals have fallen } \\
4 \text { weeks after } 1 \\
6 \text { or } 7 \text { weeks after } 2\end{array}$ & $\begin{array}{l}\text { When most petals have fallen. } \\
2 \text { to } 3 \text { weeks after } 1 \text {. } \\
2 \text { weeks after } 2 \text {. }\end{array}$ \\
\hline Schedule 4_- & $\left\{\begin{array}{l}\text { 1. Calyx spray } \\
\text { 2. First cover spray } \\
\text { 3. Second cover spray } \\
\text { 4. Third cover spray }\end{array}\right.$ & $\begin{array}{l}\text { When most petals have fallen } \\
2 \text { to } 3 \text { weeks after } 1 \\
2 \text { weeks after } 2 \\
6 \text { or } 7 \text { weeks after } 2\end{array}$ & $\begin{array}{l}\text { When most petals have fallen. } \\
2 \text { to } 3 \text { weeks after } 1 \text {. } \\
2 \text { weeks after } 2 \text {. } \\
7 \text { or } 8 \text { weeks after } 2 \text {. }\end{array}$ \\
\hline Schedule 5 & $\left\{\begin{array}{l}\text { 1. Calyx spray } \\
\text { 2. First cover spray } \\
\text { 3. Second cover spray } \\
\text { 4. Third cover spray } \\
\text { 5. Fourth cover spray }\end{array}\right.$ & $\begin{array}{l}\text { When most petals have fallen } \\
8 \text { to } 21 \text { days after } 1 \\
8 \text { to } 10 \text { days after } 2 \\
16 \text { to } 20 \text { days after } 2 \\
6 \text { to } 7 \text { weeks after } 2\end{array}$ & $\begin{array}{l}\text { When most petals have fallen. } \\
2 \text { to } 3 \text { weeks after } 1 \text {. } \\
2 \text { weeks after } 2 \text {. } \\
7 \text { or } 8 \text { weeks after } 2 \text {. } \\
2 \text { or } 3 \text { weeks after } 4 \text {. }\end{array}$ \\
\hline Schedule 6 & $\left\{\begin{array}{l}\text { 1. Calyx spray } \\
\text { 2. First cover spray. } \\
\text { 3. Second cover spray. } \\
\text { 4. Third cover spray } \\
\text { 5. Fourth cover spray. } \\
\text { 6. Fifth cover spray }\end{array}\right.$ & $\begin{array}{l}\text { When most petals have fallen } \\
8 \text { to } 21 \text { days after } 1 \\
8 \text { to } 10 \text { days after } 2 \\
16 \text { to } 20 \text { days after } 2 \\
6 \text { to } 7 \text { weeks after } 2 \\
10 \text { to } 11 \text { weeks after } 2\end{array}$ & \\
\hline Schedule 7 & $\left(\begin{array}{l}\text { 1. Calyx spray } \\
\text { 2. First cover spray } \\
\text { 3. Second cover spray. } \\
\text { 4. Third cover spray } \\
\text { 5. Fourth cover spray. } \\
\text { 6. Fifth cover spray } \\
\text { 7. Sixth cover spray }\end{array}\right.$ & $\begin{array}{l}\text { When most petals have fallen } \\
8 \text { to } 21 \text { days after } 1 \\
8 \text { to } 10 \text { days after } 2 \\
16 \text { to } 20 \text { days after } 2 \\
24 \text { to } 30 \text { days after } 2 \\
6 \text { to } 7 \text { weeks after } 2 \\
10 \text { or } 11 \text { weeks after } 2\end{array}$ & \\
\hline
\end{tabular}

\section{DUSTING MATERIALS}

Dust mixtures have not been so satisfactory as liquid sprays, on the whole, although in some instances they have been used successfully. A mixture containing 10 percent of lead arsenate, 75 percent of sulfur, and 15 percent of filler, such as gypsum or hydrated lime, finds some use as a combination insecticide and fungicide. Nicotine dusts, composed of hydrated lime impregnated with nicotine, are much used on truck crops and may also be used on fruit trees. Dusting must be done in calm weather if it is to be successful.

\section{TREE-BANDING MATERIALS}

Bands of burlap or corrugated paper may be used to trap larvae of the codling moth. If the paper bands are impregnated with a mixture of beta-naphthol and oil, as mentioned on page 5, it will not 
be necessary to remove them at intervals to destroy the larvae that crawl into them (fig. 82). Bands are also valuable to prevent climb-

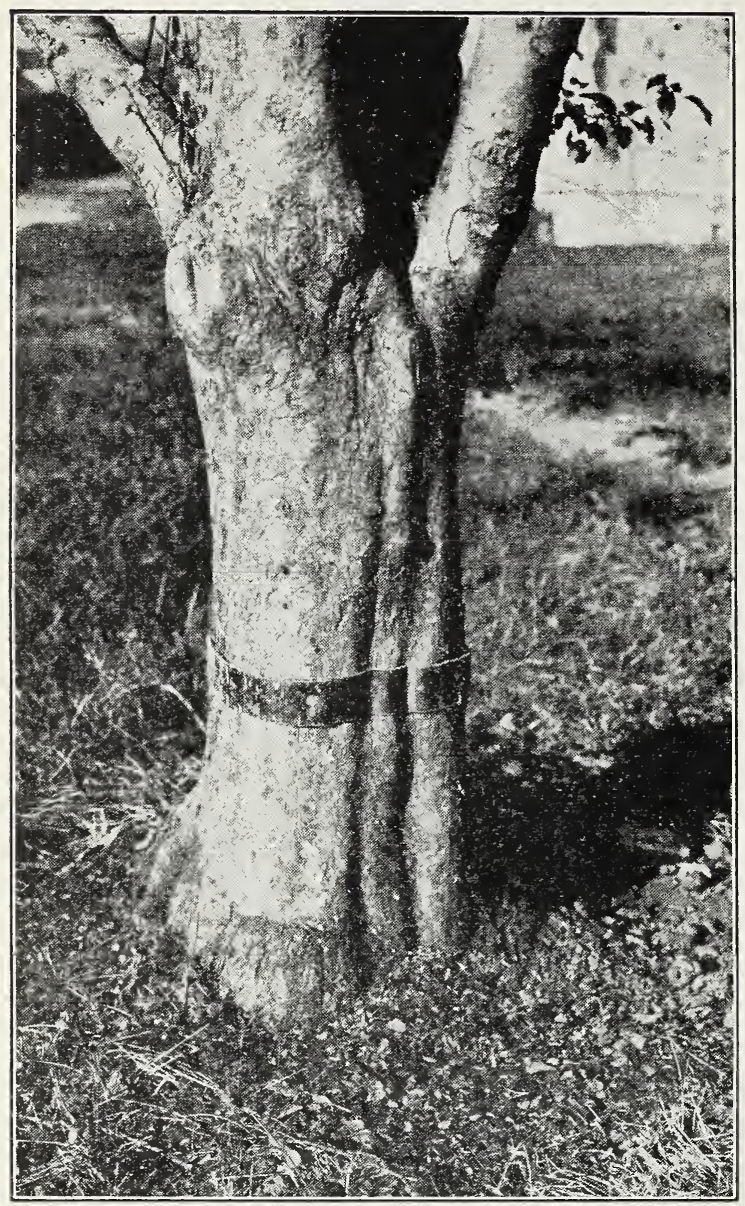

Figure 82.- Chemically treated band on apple tree. ing cutworms from getting into the trees. Their use for this purpose is explained on page 33 .

\section{BAITS AND LIGHTS}

Poisoned baits may be used for combating cutworms, as explained on page 34 . Attractive baits, composed of about 1 part of good molasses to 10 or 15 parts of water, are very useful for indicating the presence of codling moths in the orchard. For this purpose the bait should be placed in a suitable container, such as a small kettle with a bail, suspended near the top of a tree from a pole by means of a cord and pulley, so that it may be lowered for examination (fig. 83). The level of the liquid should be maintained by adding water, and the whole contents should be replaced every 10 days or 2 weeks. In cool weather a small quantity of yeast should be added, as the bait is more attractive when fermenting. Four or five of these baits scattered about an orchard are sufficient. They should be examined daily and the number of codling moths caught should be recorded. These baits catch large numbers of moths, but it has not been demonstrated that they are worth their cost for actual control, although they are very valuable in determining when to spray. Lights are attractive to some insects, but, with the possible exception of the codling moth, no orchard insect in the Pacific Northwest is attracted in sufficient numbers to warrant the use of lights. It has not yet been proved whether they can be used economically as a control for the codling moth. 


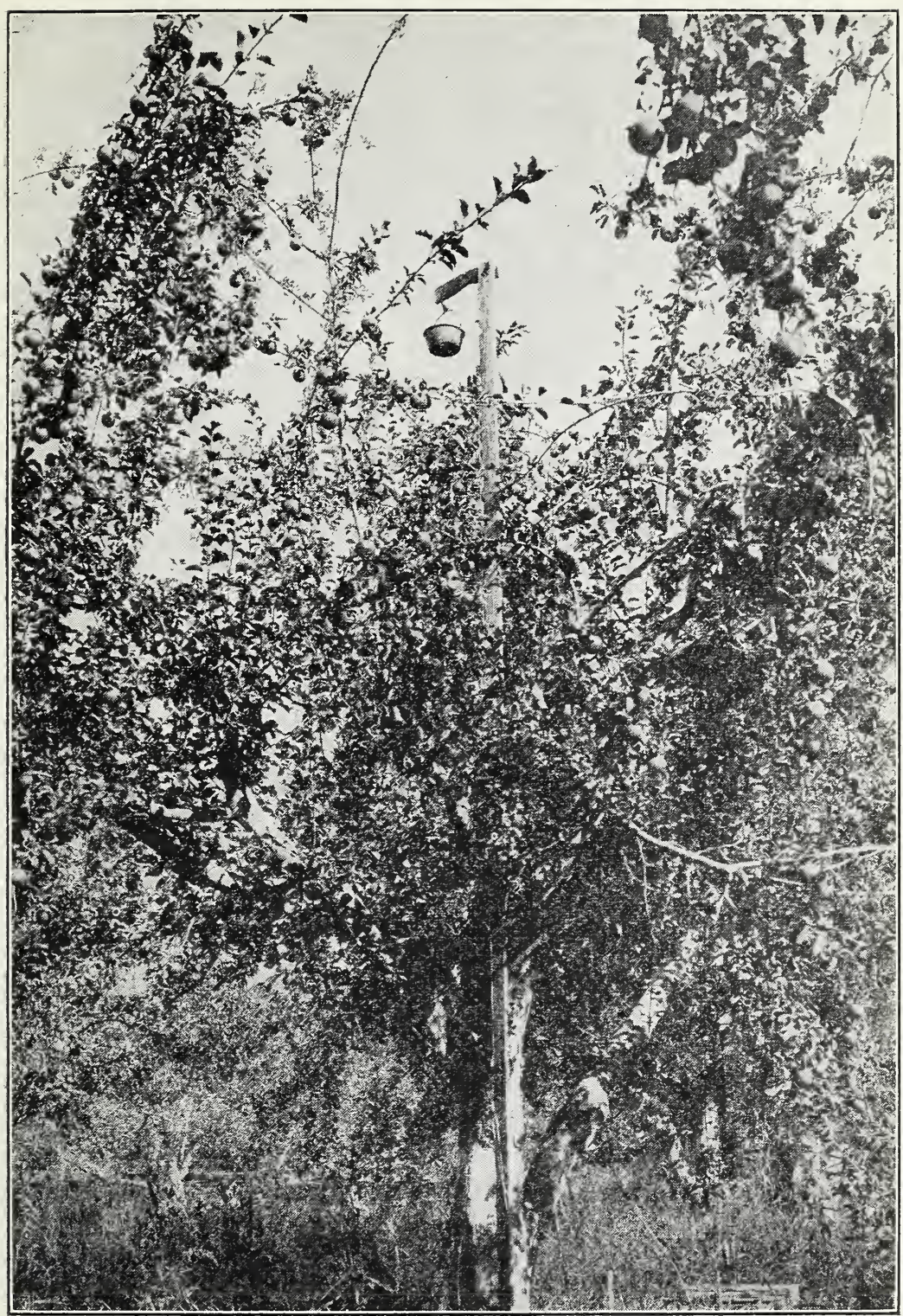

FIGURE 83.-- Codling moth bait in position in apple tree.

\section{ORCHARD METHODS AND SANITATION}

The effectiveness of spraying may be increased by planting trees at such a distance apart that the branches will not interlock, by pruning them in such a manner that all parts may be sprayed thoroughly, and by thinning the clusters of fruit so that only one fruit 
remains. Water sprouts and suckers should be removed, for aphids and other insects often occur on them in large numbers.

Boxes, boards, sacks, and rubbish should not be permitted to accumulate in or near an orchard, as they afford excellent protection to larvae of the codling moth and other hibernating insects.

Alfalfa and other leguminous cover crops are necessary in most of the bearing orchards of the Pacific Northwest. Their use sometimes interferes with the control of certain insects, such as the treehoppers and the tarnished plant bug. Cover crops are not so necessary in young orchards, and clean cultiration may prevent injury by these insects. 


\section{INDEX}

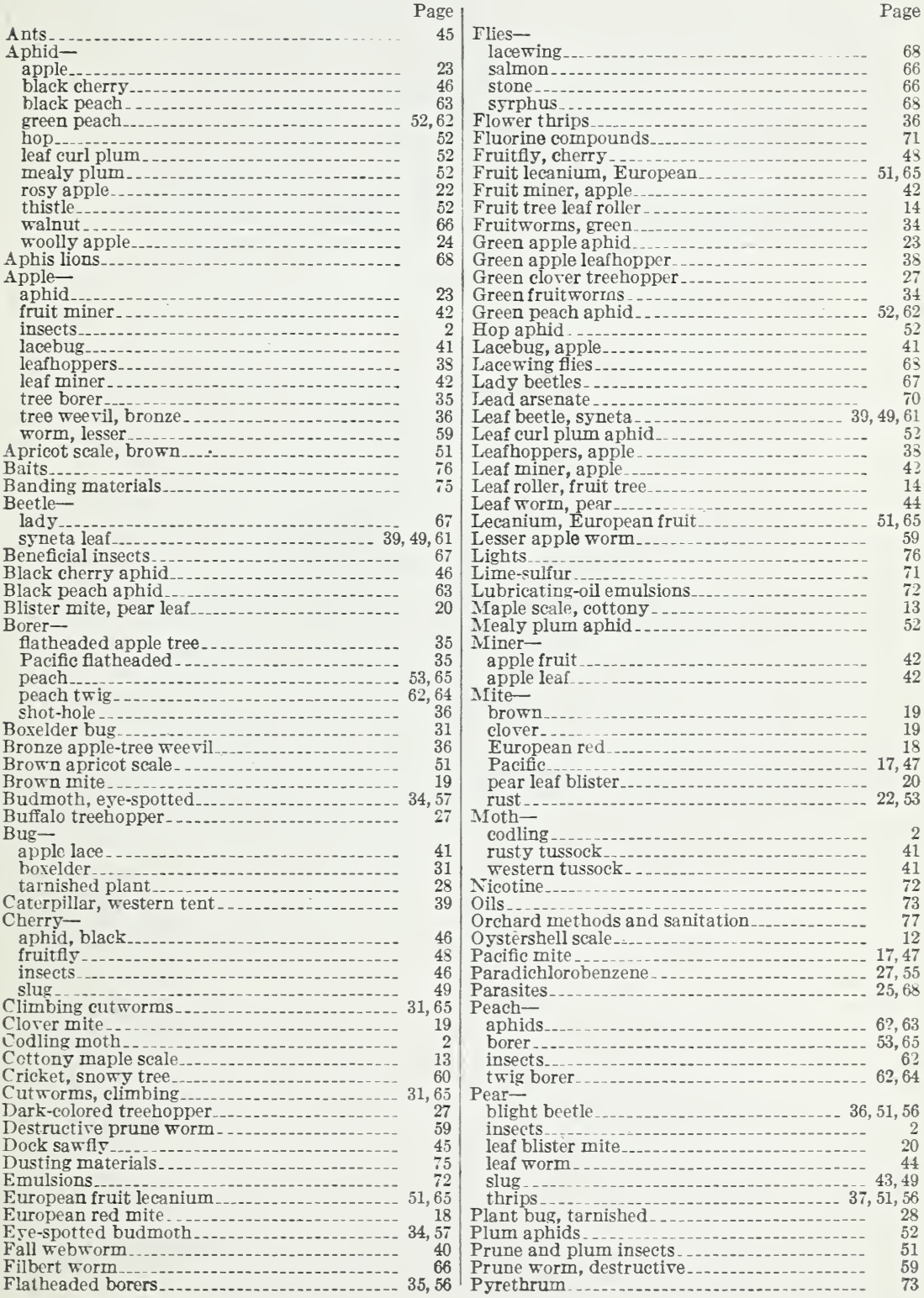




\begin{tabular}{|c|c|}
\hline Page & Page \\
\hline Red mite, European & 52 \\
\hline Red spiders $\ldots$ & Thrips- \\
\hline Losy apple aphid & \\
\hline otenone & $37,51,56$ \\
\hline 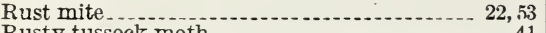 & Tree- \\
\hline $\begin{array}{l}\text { Rusty tussock moth } \\
\text { Salmon flies }\end{array}$ & banding material \\
\hline San Jose scale. & $\begin{aligned} \text { cri } \\
\text { Tree }\end{aligned}$ \\
\hline Sawfly, dock. 45 & k moths. \\
\hline $\begin{array}{l}\text { Scale- } \\
\text { brown aprico }\end{array}$ & orer, peaci. \\
\hline $\begin{array}{l}51 \\
13\end{array}$ & Wa \\
\hline 12 & $\begin{array}{l}\text { Webworm, fall } \\
\text { Weeril, bronze apple tree }\end{array}$ \\
\hline $9,46,51,65$ & Western- \\
\hline $\begin{array}{l}\text { Shot-hole borer-.-...... } \\
\text { Slug, pear }\end{array}$ & tent caterpillar \\
\hline $\begin{array}{l}43,43 \\
\ldots\end{array}$ & tu \\
\hline schedules.- & Woolly apple aphid \\
\hline 70 & Worm- \\
\hline d stickers & destructive prune...... \\
\hline & 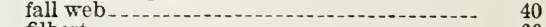 \\
\hline $39,49,61$ & \\
\hline & fruit \\
\hline (1) & les \\
\hline ostern & pear leaf \\
\hline
\end{tabular}


their being mistaken for food or medicine, and they should be stored in a place where children and others unaware of their dangerous character cannot gain access to them. If fully safe storage facilities cannot be provided, the quantities purchased should be only sufficient for the current work, and the storage of these dangerous chemicals thus avoided. More detailed suggestions regarding certain of the materials follow.

Lead arsenate (p. 70) and calcium arsenate.-These materials are used for the control of the codling moth (pp. 2-8) and other chewing insects. They are very poisonous when taken into the system. When they are applied as dusts, or are being prepared for use as spray mixtures, the breathing of the dry material should be avoided. When prolonged exposures to arsenical dusts cannot be avoided the operator should wear a suitable type of respirator. The hands should be kept away from the mouth and should be well washed before food is handled or eaten. The wearing of oiled leather gloves is helpful.

Cryolite and other fluorine compounds (p. 71).-These are used for codling moth control (pp. 2-8). The same precautions should be followed as with the arsenicals.

Nicotine (p. 73).-Nicotine is used as a contact spray for sucking insects (pp. 23, 24 , etc.), and also to some extent for controlling the codling moth (pp. 2-8). It is a very poisonous material, although individual susceptibility varies greatly. Some persons can apply it freely without suffering any noticeable effects, whereas others may develop acute nausea. Those who experience difficulty of this kind should protect themselves by the use of a respirator of a type which uses pads saturated with acetic or citric acid. Illness can also be caused by the absorption of nicotine through the skin, and operators should avoid the continued wearing of clothing that has become saturated with spray solutions containing nicotine.

Lime-sulfur (p. 71).-Lime-sulfur is used for the control of the San Jose scale (pp. 9-11) and red spiders and mites (pp. 16-22), and is also used as a fungicide. It is very caustic to the skin, especially when used in high concentrations as when fruit trees are sprayed during their dormant period. Persons exposed to this material should protect their faces by covering them with grease or petroleum jelly before they begin spraying, and should avoid getting any of the material into the eyes, which would cause acute temporary discomfort. Hands may be protected by wearing oiled leather gloves. 
